UNIVERSIDADE DE SĀO PAULO

INSTITUTO DE GEOCIENCIAS E ASTRONOMIA

\title{
ASPECTOS GEOQUÍMICOS
}

RIOS DA BACIA DO PARANÁ

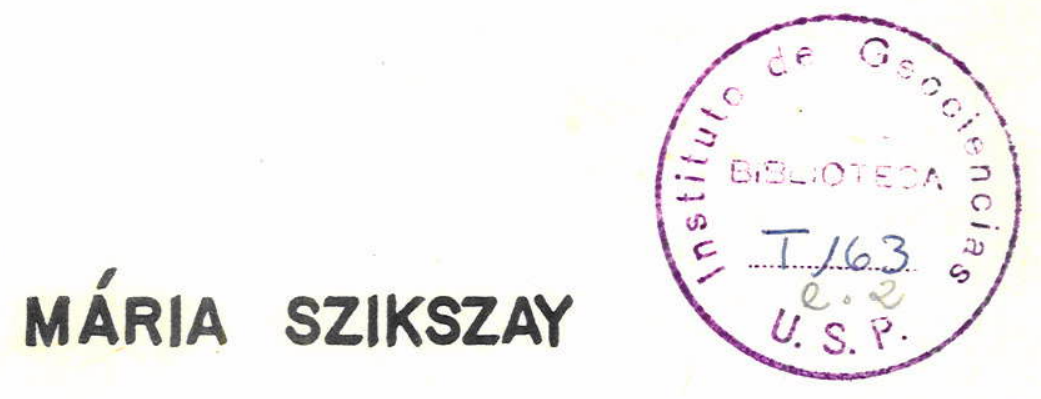

DEDALUS - Acervo - IGC

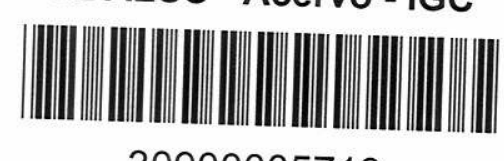

30900005713

Tese de Doutoramento

1972 
UNIVERSIDADE DE SÃO PAULO

INSTITUTO DE GEOCIENCIAS E ASTRONOMIA

ASPECTOS GEOQUIMICOS DE RIOS DA BACIA DO PARANÁ

Märia SZIKSZAY

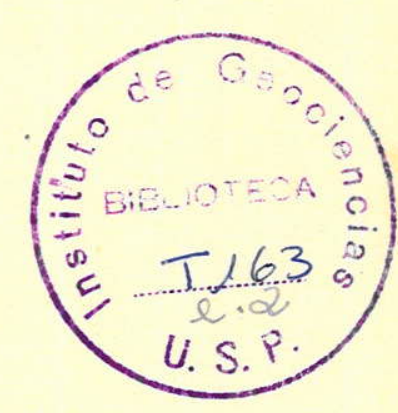

Orientador: Prof. Dr. Viktor LEINZ

Tese de Doutoramento

1972 
I. INTRODUÇÃO
a - O Problema
b - Generalidades
c - Trabalhos anteriores
d - Finalidade
e - Agradecimentos

1

II. BACIA DO RIO DA PRATA
a - Generalidades
b - Geologia
c - Solos
d - Clima
a - Coleta
b - Anälises

1. Aparelhagem

2. Técnicas Utilizadas

2.1.Filtragem

2.2. Secagem

2.3. Estudo Espectrográfico

\subsubsection{Padrões}

2.3.2. Preparação dos eletrodos das amostras

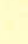

(1)

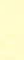

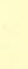


a - Resultados gerais dos rios estudados

1. Rios da margem direita do rio Paraná

1.1. Rio Sucuriú

1.2. Rio Verde

1.3. Rio Pardo

2. Rios da margem esquerda do rio Paraná

2.1. Rio Tietê

2.2. Rio Paranapanema

3. Rio Paraná e seus formadores

3.1. Rio Paranaíba

3.2. Rio Grande

3.3. Rio Paraná

4. Rio Pelotas-Uruguai

b - Comparação da Composição Química dos rios das margens direita e esquerda do rio Parana

c - Relação entre concentração e vários fatôres

1. Relação da concentração dos ele mentos com a variação sazonal

2. Relação da concentração dos ele mentos com a vazao

3. Relação da concentração dos ele mentos com $\mathrm{opH}$

d - Classificação das ăguas dos rios es tudados 
V. QUANTIDADE TOTAL DE MATERIAL DISSOLVIDO

a - Quantidade de material dissolvido por ano

1. Rio Sucuriú 99

2. Rio Verde 100

3. Rio Pardo 101

4. Rio Tietê 102

5. Rio Paranapanema . 103

6. Rio Paraná 104

$\begin{array}{ll}\text { b - Quantidade de material dissolvido } & \\ \text { por } \mathrm{km}^{2} / \text { ano } & 105\end{array}$

VI. COMPARAÇÃO ENTRE AS COMPOSIÇÕES QUIMICAS DOS RIOS BRASILEIROS ESTUDADOS COM OUTROS RIOS E OCEANOS

a - Comparação de rios brasileiros com rios da América do Sul

b - Comparação dos elementos traços dos rios estudados com os de outros paí ses e Oceanos

c - Comparação entre a quantidade de ma terial dissolvido dos rios estudados com outros rios

VII. CONCLUSÕES

VIII. BIBLIOGRAFIA 
1. Coluna geológica da bacia do Paraná (seg. Mendes e Petri, 1971)

2. Linhas de comprimento de onda utilizadas

3. Elementos maiores e menores dosados nas águas do rio Sucuriú (mg/l e percentagem do resíduo)

4. Elementos traços dosados nas águas do rio Sucuriú (mg/l e percentagem do resíduo)

5. Elementos maiores e menores dosados nas águas do rio Verde (mg/l e percentagem do resíduo)

6. Elementos traços dosados nas águas do rio Verde (mg/l e percentagem do resíduo)

7. Elementos maiores e menores dosados nas águas do rio Pardo (mg/l e percentagem do resíduo)

8. Elementos traços dosados nas águas do rio Pardo (mg/l e percentagem do resíduo)

9. Elementos maiores e menores dosados nas águas do rio Tietê (mg/l e percentàgem do resíduo)

10. Elementos traços dosados nas águas do rio Tietê (mg/l e percentagem do resíduo)

11. Elementos maiores e menores dosados nas águas do rio Paranapanema (mg/l e percen tagem do resíduo)

12. Elementos traços dosados nas águas do rio Paranapanema (mg/l e percentagem do resíduo)

13. Elementos maiores e menores dosados nas águas do rio Paranaíba (mg/l e percentagem do resíduo)

14. Elementos traços dosados nas águas do rio Paranaíba (mg/l e percentagem do resíduo)

15. Elementos maiores e menores dosados nas águas do rio Grande (mg/l e percentagem do resíduo) 
16. Elementos traços dosados nas águas do rio Grande ( $\mathrm{mg} / \mathrm{l}$ e percentagem do resíduo)

17. Elementos maiores e menores dosados nas águas do rio Paraná, Ilha Solteira (mg/l e percentagem do resíduo)

18. Elementos maiores e menores dosados nas águas do rio Paraná, Jupiá (mg/l e percen tagem do resíduo)

19. Elementos maiores e menores dosados nas águas do rio Paraná (mg/l e percentagem)

20. Elementos traços dosados nas águas do rio Paraná (mg/l e percentagem do resíduo)

21. Razão solução/suspensão do material do rio Paraná

22. Elementos maiores e menores dosados nas águas do rio Pelotas (mg/l e percentagem do resíduo)

23. Elementos maiores e menores dosados nas águas do rio Uruguai (mg/l e percentagem)

24. Elementos traços dosados nas águas do rio Pelotas (mg/l e percentagem do resíduo)

25. Elementos maiores, menores e elementos traços de todos os rios estudados (mg/l de resíduo)

26. Elementos maiores, menores e elementos traços de todos os rios estudados (per centagem)

27. Cálculo da quantidade de material dissolvido - Rio Sucuriú

28. Cálculo da quantidade de material dissolvido - Rio Verde

29. Cálculo da quantidade de material dissolvido - Rio Pardo

30. Cálculo da quantidade de material dissolvido - Rio Tietê

31. Cálculo da quantidade de material dissolvido - Rio Paranapanema 
32. Cálculo da quantidade de material dissolvido - Rio Paraná

33. Cálculo da quantidade de elementos dissol vidos em $\mathrm{km}^{2} / \mathrm{ano}$

34. Composição média dos rios estudados compa rada com a média dos rios da América do $\mathrm{Sul}(\mathrm{mg} / \mathrm{l})$

35. Comparação dos elementos traços ( $\mathrm{mg} / \mathrm{I}$ )

36. Comparação da quantidade de material dissolvido

1. Mapa hidrográfico da bacia do Rio da Prata (seg. Publicação da Organização dos Estados Americanos, 1969)

2. Esbôço geológico (modificado de Leinz, 1937 e DNPM - Divisão de Geologia e Mineralogia, 1960) e localização dos pontos de coleta

3. Esquema da repartição climática mensal no Sul do Brasil (Pedro, Melfi, Queiroz,1970)

4. Mapa de precipitação média anuã da bacia do rio da Prata (seg. Publicação da Organi zação dos Estados Americanos, 1969)

5. Comparação de cátions e ânions dos rios Ver de e Pardo

6. Comparação dos elementos traços dos rios Verde e Pardo

7. Distribuição dos elementos maiores ( Rio Paraná - Ilha Solteira, mesmo dia)

8. Comparação dos elementos maiores (Rio Para ná - Ilha Solteira, épocas diferentes)

9. Distribuição dos elementos maiores (cátions) durante o ano de 1964 (Rio Paraná-Jupiá). 
10. Distribuição dos elementos maiores (ânions) durante o ano de 1964 (Rio Paraná-Jupiá)

11. Comparação dos elementos maiores (Rio Paraná-Jupiā, 26.10.1964 e 26.10.1970)

12. Comparação dos elementos maiores (Rio Paraná-Ilha Solteira e Jupiá, 26 de outubro de 1970)

13. Comparação dos elementos traços (Rio Paraná-Ilha Solteira e Jupiá, 26 de outubro de 1970)

14. Relação do material em solução e em suspen são, no mesmo dia (Rio Paraná-Ilha Solteira)

15. Relação do material em solução e em suspensão, durante um ano (Rio Paraná-Jupiá)

16. Comparação da composição química média dos rios da margem direita e esquerda do rio Paraná

17. Relação entre a quantidade de material dissolvido e a variação das estações (Rio Para ná-Jupiá)

18a.Comportamento dos elementos maiores (cátions) de acôrdo com a variação das estaçôes (Rio Paraná-Jupiá)

18b.Comportamento dos elementos maiores (cátions) de acôrdo com a variação das estações (Rio Paraná-Jupiá)

19. Comportamento dos elementos maiores (ânions) em relação a variação das estações (Rio Para ná-Jupiá)

20. Relação entre a vazão dos rios Paraná, Tietê, Paranapanema, Sucuriú, Verde e Pardo, com a variação das estações

21. Relação de material em solução e vazão (Rio Paraná-Jupiá, 1964)

22a.Relação dos elementos maiores (cátions) com a vazão (Rio Paraná-Jupiá, 1964)

22b.Relação dos elementos maiores (cátions) com a vazão (Rio Paraná-Jupiá, 1964) 
23. Relação dos elementos maiores (ânions) com a vazão (Rio Paraná-Jupiá, 1964)

24a. Relação dos elementos maiores (cátions)com $\circ \mathrm{pH}$

24b. Relação dos elementos maiores (cátions)com $\circ \mathrm{pH}$

25. Relação dos elementos maiores (ânions) com $\circ \mathrm{pH}$

26a. Relação dos elementos traços com $0 \mathrm{pH}$

26b. Relação dos elementos traços com $\circ \mathrm{pH}$

27. Relação da vazão com $\circ \mathrm{pH}$

28. Mëdia das concentrações de carbonatos, sul fatos, cloretos e nitratos dos rios estudā dos

29. Média geral de todos os rios estudados com parados com valôres médios de rios da América do Sul

30. Comparação dos elementos traços dos rios estudados com outros rios e Oceanos 


\section{INTRODUÇÃO}

\section{a - 0 Problema}

Os rios da bacia hidrográfica do Paraná drenam uma ärea de $1510000 \mathrm{~km}^{2}$, considerada a segunda maior bacia hidrográfica do Brasil. A falta de estudos sô bre a composição química das äguas dos rios brasilei ros, levou-nos à realização da presente pesquisa. A re gião sendo razoâvelmente conhecida do ponto de vista geológico, facilita certos tipos de interpretação e permite um maior relacionamento entre dados de composi ção das soluções com a litologia. Outra vantagem que encontramos na realização dêste trabalho, foi a exis tência na ärea, de muitos pontos de observação, com me didas de vazão dos rios, como também estações meteoro lógicas, cujos dados sôbre precipitações são de grande importância no estudo da quantidade de sais dissolvi dos nas äguas dos rios.

\section{b - Generalidades}

As águas de precipitação atmosférica atingindo - solo se dividem em três partes: uma parte se infil tra e alimenta as reservas das águas subterrâneas e as fontes, uma outra retorna à atmosfera pela evaporação e a terceira parte se escoa pela superfície. As äguas que percolam rochas e solos, atacam os constituintes minerais, solubilizando e lixiviando as partes mais so lúveis e carregando pequenas partículas em suspensão. Tais águas percolantes junto com as águas de escoamen to formam pequenos cörregos, que juntando-se formam pe quenos riachos os quais evoluem para formar os rios. Formados assim, os rios, cujas águas, jã não são as äguas puras da precipitação atmosférica, continuam dis solvendo, adicionalmente, certas quantidades de sais 
provenientes de materiais em suspensão (adquiridos prè viamente por processos físicos, químicos e físico-quími cos). A atividade da matéria orgânica, por sua vez, ré tira fosfatos, nitratos e silicatos da água, utilizando-os como nutrientes para os organismos. Com o tempo os organismos morrem devolvendo aquêles elementos (retira dos das águas e neles concentrados) para as águas dos rios.

Além do material em solução, as correntes em mo vimento têm também capacidade de realizar um trabalho físico, erodindo os canais por onde percorrem,adicionan do um outro tipo de material, que é o material em sus pensão. Desta maneira, os rios transportam uma quanti dade considerável de material não sòmente em solução, mas também em suspensão para os oceanos.

Um outro tipo de material transportado pelos rios são as partículas coloidais. Como exemplos princi pais temos os hidróxidos de ferro, de alumínio, silício e às vêzes coloides orgânicos.

Em virtude de contínuas transformações, os rios constituem um sistema dinâmico muito complexo. Sua com posição química revela, dessa forma, os constituintes das águas num momento particular. Sua composição é ex tremamente variável, e depende de numerosos fatôres. En tre outros destacam-se os tipos de solo e rocha, o cli ma da região e o volume de água do rio. 0 fatôr mais importante para introduzir variabilidade temporária na composição química das àguas dos rios, é a contribuição da água subterrânea e da água de escoamento.

\section{c - Trabalhos anteriores}

Muitas pesquisas foram realizadas sôbre a maté ria em questão, visando porém, outros objetivos, tais como os relacionados à construção de barragens, poluição 
das águas e alguns outros restritos à prospecção geoquí mica. Dados coletados para objetivar o ponto de vista geoquímico quase não existem no Brasil. Em geral estu da-se um único elemento ou alguns elementos traços, mas estudos completos sôbre elementos maiores e elementos traços das mesmas águas, são escassos.

Para exposição ilustrativa veremos alguns traba Ihos conhecidos a respeito da composição química dos rios em seus elementos maiores, menores e elementos tra ços.

Sôbre êstes constituintes (maiores, menores e elementos traços) existem estudos de rios de todos os continentes.

$\mathrm{Na}$ Europa as ăguas dos rios maiores vêm sendo analisadas já há mais de um século (Clarke, 1924). Aná lises mais modernas foram feitas na Inglaterra por Gorham (1958), na Alemanha por Heide (1952) e outros. Nos países nórdicos e mediterrâneos, existem estudos re centes sôbre vários rios. Na União Soviética, Alekin e Brashnikova (1957) estudaram a composição média de di versos rios, enquanto Maliuga (1945) investigou os ele mentos traços: Os trabalhos mais completos são de Konovalov (1941) relativos à prospecção geoquímica,e em 1959 sôbre elementos traços de inúmeras bacias hidrográ ficas, concluindo que as concentrações, salvo algumas exceções, mostram pouca variação durante 0 ano. Segundo Konovalov (1959) o boro, bromo, iodo e fluor são proemi nentes em águas de rios que drenam äreas sedimentares de origem marinha, sendo o cobre e o zinco mais comuns em rios que se originam em regiões montanhosas. 0 autor restringe-se exclusivamente à influência da litologia na composição dos elementos traços dos rios. 0 trabạ tho mais recente na França é de Tardy (1971) sôbre ca racterização de tipos de intemperismo pela geoquímica das äguas. 
No continente asiätico, existem anälises dos rios de diversós países como por exemplo, India, Iran, Turquia, Afganistão, etc. No Japão, existem estudos ex tensos feitos por vários autores, entre êles Hanya et al. (1950), Iwasaki et al. (1954a, 1954b), Kimura et al. (1950) e Yamamoto (1952). Dados mais completos encon tram-se nos trabalhos de Kobayashi (1960), referentes à composição quĩmica de quase todos os rios do Japão.

Na Austrälia, entre outros, Hutton e Leslie (1958) investigaram o conteúdo de cloretos em águas de rios, colocando em dúvida a origem marinha dêste íon.

$\mathrm{Na}$ Africa devem ser mencionados os trabalhos de Lucas (1908) sôbre a composição química do rio Nilo e o de Clerfayt (1956) sôbre composição do rio Congo. Na Âfrica do Sul existe ainda o trabalho de de Villiers (1962) sôbre elementos maiores e elementos traços do rio Orange. Os resultados de de Villiers mostraram que a quantidade de sais dissolvidos por litro, era máxima quando a vazão era mínima e que os monohidrogeno carbo natos (bicarbonatos) de cálcio e de magnésio, bem como - cloreto de sódio são os sais predominantes. Os ele mentos traços estão apresentados em tabelas sem qual quer interpretação.

No continente norte-americano a maior parte dos estudos referentes à composição química dos rios foram executadas pela "Division of Water Recourses" do "Geolo gical Survey of America". Os estudos tratam não só das análises de grandes bacias, como também de rios separa damente. Os estudos mais completos são de Durum e Haffty $(1960,1963)$. No primeiro trabalho mostram da dos sôbre conteúdo médio de elementos menores em alguns grandes rios do mundo. Relacionam também o conteúdo de elementos menores de rios da costa Atlântica com os da costa Pacifica. No trabalho publicado em 1963, os refe ridos autores apresentam dados de vinte e seis elemen 
tos traços, estudando o conteúdo em estrôncio, urânio e rádio das águas analisadas sem contudo interpretar os dados obtidos. Descrevem, ainda, as técnicas de anäli ses espectrográficas utilizadas. Kleinkopf $(1955,1960)$ estudou elementos traços com a finalidade de prospecção geoquímica, usando também para análise de elementos trạ ços o espectrógrafo. Outro trabalho recente é de Kharkar et al. (1968), no qual são citados elementos traços de dez rios dos Estados Unidos da América do Nor te, do Rhone na França e do Amazonas no Brasil. Os au tores acima citados, além de discutirem pormenorizadamente o método utilizado nas anālises (ativação de neu trons), fornecem dados da quantidade de alguns elemen tos traços transportados em solução para os oceanos, nos rios por êles investigados. No Canadá, são conhecí dos os trabalhos de Leverin (1947) e Durum e Haffty (1963), referentes a presença de alguns elementos nas águas dos rios.
\end{abstract}

$\mathrm{Na}$ América do Sul, Livingstone (1963) cita an lises feitas na Venezuela em águas de oito rios. N. Guiana Britânica, anālises de alguns constituintes menc res foram realizadas por Harrison e Reid (1913). Na Ar gentina, $\vec{e}$ bem conhecido o trabalho pioneiro de Kyle, realizado em 1897. Mais recentemente, Pastore e Huido boro (1952) analisaram águas de trinta e sete rios e de diversas fontes. No Peru, Maldonado e Guevara (1950) estudaram o boro nas águas de alguns rios.

No Brasil o trabalho mais antigo é de Katzer (1903) sôbre análises feitas em amostras coletadas nos rios Amazonas (em óbidos), Xingú e Tapajós. Há o traba tho recente de Gibbs (1967), sôbre a bacia do rio Amazo nas cujos resultados referem-se ao material em suspen são. Gibbs relacionou a quantidade de sais dissolvidos e o conteúdo de sólidos em suspensão com o relêvo, que $\bar{e}$, segundo o autor, o fator mais importante na caracte 
rização do intemperismo físico e químico. A composição das águas em elementos maiores, menores e elementos tra ços do rio Paraíba foi estudada por Szikszay (1967).Com parando os resultados obtidos em amostras coletadas no inverno e no verão, observou-se que sódio,potássio, fer ro, aluminio e cloretos, mantêm-se pràticamente constan tes, havendo diminuição em cálcio, magnésio e carbona tos e aumento em silício, no verão. A quantidade do ma terial em solução era menor no verão. A análise dos re sultados, além de ressaltar a influência da litologia na composição das águas, mostra que a quantidade de ele mentos traços diminui no curso do rio, e sua concentrá ção é menor no verão.

$\mathrm{Na}$ área do presente estudo existe $\circ$ trabalho de Povinelli e Paraguassu (1966) sôbre os rios Quilombo, Chibarro, Araras e Negro na região de São Carlos, Esta do de São Paulo. Através do pH, condutividade elétrica, dureza e teor em ferro, os autores procuraram estabele cer relações entre a litologia e o material carregadó na drenagem. Os resultados evidenciaram a estreita de pendência das características físico-químicas da água dos rios com as condições geológicas da área estudada. Szikszay (1969) estudou a composição química do rio Tí. tê em seus elementos maiores, menores e elementos tra ços.

\section{d - Finalidade}

O significado dos elementos nas águas dos rios apresenta muitos problemas, que precisam ser determina dos se quisermos interpretar teorias sôbre o ciclo geo químico e migração dos elementos.

A finalidade principal dêste estudo é de reco nhecimento, informando sôbre a composição dos rios de parte da bacia do Paraná. Pretende-se caracterizar as águas dos rios que drenam regiões tropicais e subtropi cais de clima úmido, uma vez que a maior parte do conhẹ 
cimento existente refere-se a climas não existentes no Brasil. Outro objetivo é estudar o comportamento dinâ mico dos elementos e tentar interpretar êstes dados ré lacionando-os com fatôres físicos, geológicos e físico-químicos, como litologia, clima, vazão e pH do meio.

Estudou-se sòmente o material em solução, pois - comportamento dos íons solúveis obedece as leis que regem o ciclo exógeno.

Os dados obtidos na presente pesquisa, poderão contribuir para o conhecimento geoquímico dos rios des ta vasta årea que é a bacia do Paraná, onde não se co nhece a quantidade nem a qualidade dos sais dissolvidos em suas ăguas, nem suas relações com as rochas, solos e erosão; bem como as consequências dêste material retira do.

Foi calculado, com base nos dados obtidos, a quantidade dos elementos removidos em solução, a partir da vazão e da área drenada. Êste dado reputamos de grandé importância, pois fornece, em parte, uma idéia bastante clara sôbre o empobrecimento dos solos e suas consequências agronômicas.

\section{e - Agradecimentos}

Ao término desta pesquisa, formulamos ao Profes sor Doutor VIKTOR LEINZ os mais sinceros agradecimentos pela valiosa orientação proporcionada durante a realiza ção dêste trabalho, e ao Professor Doutor JOSUE CAMARGO MENDES, pelo auxílio concedido à esta pesquisa.

Agradecemos, também, aos Professôres Dr. ADOLPHO JOSE MELFI e Dr. FRANCO LEVI, pelas criticas e suges tões ao trabalho, e pelo auxílio prestado à realização das análises espectrográficas.

Durante a coleta de material destinado à análi se de laboratório, contamos com a ajuda valiosa do Pro 


\begin{abstract}
$-8-$
fessor Dr. SERGIO ESTANISLAU DO AMARAL e dos colegas ANDREA BARTORELLI, BRUNO MINIOLI E CARLOS LUCIANO ISOT TA.

O Professor Doutor DARCY PEDRO SVISERO colabo rou na correção e revisão dos textos. Além dêstes pro fessôres do Instituto de Geociências e Astronomia da Universidade de São Paulo, diversas pessoas de outras Instituições colaboraram no presente trabalho. $0 \mathrm{Sr}$. CLAUDIO COMERLATTI do Centro de Pesquisas Geocronológi cas executou algumas análises por fotometria de chama.

Os engenheiros BELLA SZIKSZAY e RUBENS BENETON, das Centrais Elétricas de São Paulo, colaboraram na co leta de amostras. 0 engenheiro FÁBRIO G. CASTRO, também pertencente às Centrais Elétricas de São Paulo, gentil mente forneceu diversos dados relativos à vazão dos rios.

Na realização das anālises dos elementos maio res, recebemos ajuda valiosa do Dr. JOÃO BATISTA CAMPOS DE PAIVA, Diretor do Laboratório de Química do Departamento Nacional da Produção Mineral (Rió de Janeiro), e das químicas VERA M. CAMPOS DE PAIVA, CECILIA M. COELHO e ELISABETH B.B. WINTER a quem agradecemos imensamente.
\end{abstract}




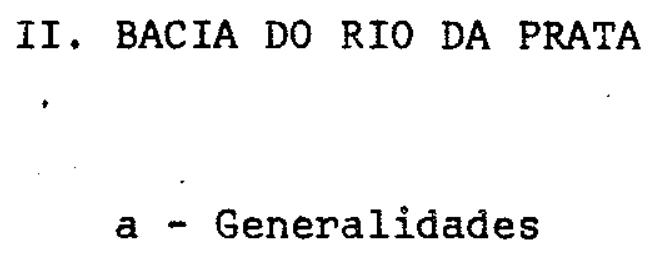

A bacia do Paraná pertence ao sistema fluvial do Rio da Prata, que abrange uma superfície de cêrca de $3100000 \mathrm{~km}^{2}$, estendendo-se pela Argentina, Brasil, Bolivia, Paraguai e Uruguai. As coordenadas extremas estão situadas entre os meridianos $67^{\circ} 08^{\prime}$ e $43^{\circ} 35^{\prime} \mathrm{W}$, e os paralelos $14^{\circ} 05^{\prime}$ e $37^{\circ} 37^{\prime} \mathrm{s}$. A maior porção dessa grande área de drenagem se encontra no Brasil, onde atinge $1415000 \mathrm{~km}^{2}$.

Cumpre diferenciar dentro do sistema, três grandes unidades hidrográficas: os rios Paraguai, Para ná e Uruguai.

Área das sub-bacias

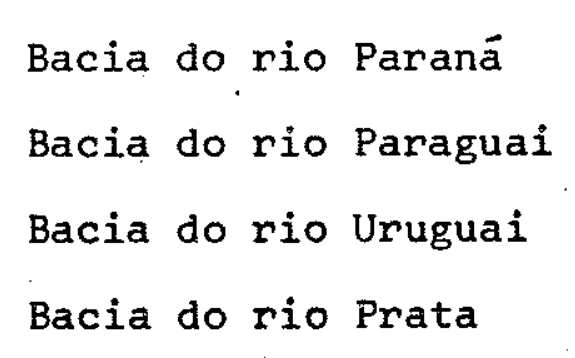

$1510000 \mathrm{~km}^{2}$

$1095000 \mathrm{~km}^{2}$ $365000 \mathrm{~km}^{2}$

$130000 \mathrm{~km}^{2}$

$3100000 \mathrm{~km}^{2}$ 


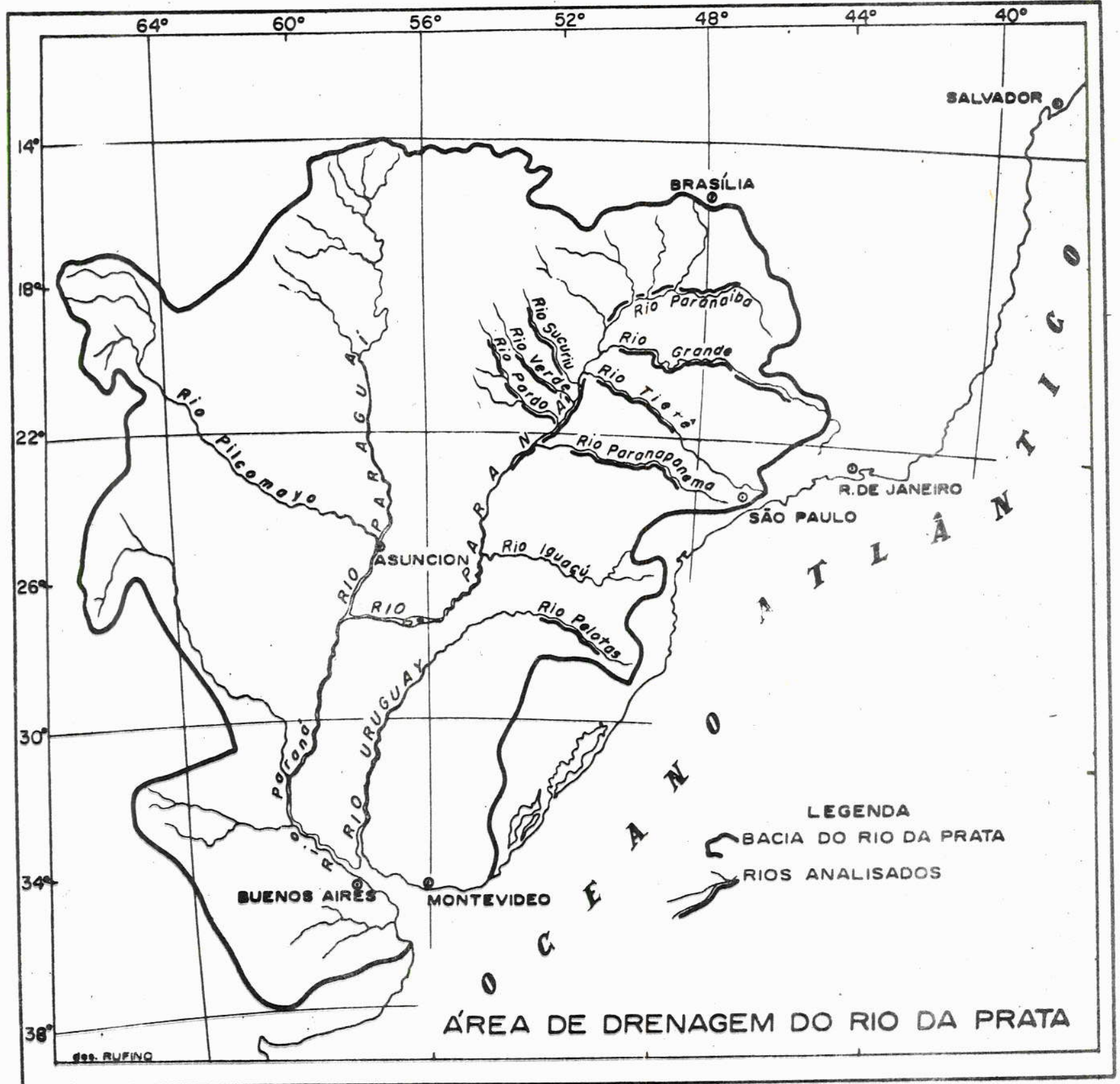

Figura 1 - Mapa hidrográfico da bacia do Rio da Prata (seg. Publicação da Organização dos Estados Americanos, 1969). 
b - Geologia

De acôrdo com Bigarella e Salamuni (1967), a bacia do Paraná originou-se em sua maior parte, como uma depressão tectônica, acompanhada por um grande número de falhas. Estes movimentos de falhamento o correram várias vêzes, como um rejuvenescimento das linhas tectônicas do pré-devoniano. Uma reativação extensiva de falhamentos ocorreu durante o Cretáceo Superior ou antes do pré-Cretáceo.

0 sistema de drenagem é controlado pelas $l \underline{i}$ nhas tectônicas. Algumas dessas falhas são muito proeminentes, como aquela que baliza o curso do rio Paraná, entre o Brasil e o Paraguai. o curso do rio Paraná na Argentina é também controlado por linhas tectônicas (Bigarella e Salamuni, 1967).

A bacia do Paraná é circundada pelo embasa mento cristalino, constituido essencialmente de ro chas metamörficas (gnaisses, xistos, filitos, quartzi tos, etc.) e igneas (granitos). São conhecidas diver sas intrusões alcalinas do Cretáceo superior.

A Tabela I, representa de forma esquemática,a coluna geológica da bacia do Paraná.

As rochas da bacia do Paraná já foram objeto de estudos detalhados do ponto de vista geológico e também geoquímico por diversos autores. Moraes Rego (1935) e Freitas (1955) estudaram e analisaram os cal cários do Grupo Bauru; Leinz (1937) analisou os tili tos e varvitos do permo-carbonífero. Os folhelhos da Formação Irati foram estudados e analisados por Ama ral (1967). Os basaltos foram estudados por Leinz (1949), Cordani e Vandoros (1967), Ruegg (1969) e Ruegg e Dutra (1970). 
$-12-$

TABELA 1

Coluna geológica da bacia do Paraná

(Seg. Mendes e Petri, 1971)

\begin{tabular}{|c|c|c|c|}
\hline Idade & Grupo & Formação & Litologia \\
\hline & Bauru & & $\begin{array}{l}\text { arenitos carboná } \\
\text { ticos } \\
\text { siltitos argilosos }\end{array}$ \\
\hline 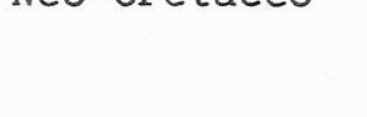 & & & $\begin{array}{l}\text { e ocasionais intru } \\
\text { sivas alcalinas }\end{array}$ \\
\hline & & Serra Geral & basaltos e diabásios \\
\hline Eo-Cretáceo & $\cdot$ & Botucatu & $\begin{array}{l}\text { arenitos infratrapia } \\
\text { nos, intratrapianos } \\
\text { e supratrapianos }\end{array}$ \\
\hline Meso-Triảssico & & Sta.Maria & $\begin{array}{l}\text { arenitos, folhelhos } \\
\text { e conglomerados }\end{array}$ \\
\hline . & & Estrada Nova & $\begin{array}{l}\text { siltitos, argilitos, } \\
\text { folhelhos e lentes } \\
\text { de calcário }\end{array}$ \\
\hline Permiano & $\begin{array}{l}\text { Passa } \\
\text { Dois }\end{array}$ & Irati & $\begin{array}{l}\text { folhelhos pirobetu- } \\
\text { minosos, calcários } \\
\text { dolomiticos e silex }\end{array}$ \\
\hline Carbonífero & Tubarão & & $\begin{array}{l}\text { diamictitos, silti- } \\
\text { tos, tilitos, areni } \\
\text { tos, varvitos, folhe } \\
\text { lhos, conglomerados } \\
\text { em parte calciferos, } \\
\text { calcários }\end{array}$ \\
\hline Devoniano & Paranä & $\begin{array}{l}\text { Ponta Grossa } \\
\text { Furnas }\end{array}$ & $\begin{array}{l}\text { folhelhos e siltitos } \\
\text { arenitos, conglomera- } \\
\text { dos e folhelhos }\end{array}$ \\
\hline Prë-Cambriano & Embasame & to cristalino & $\begin{array}{l}\text { gnaisses, xistos, fi- } \\
\text { litos, quartzitos, } \\
\text { calcärios, dolomitos, } \\
\text { granitos, etc. }\end{array}$ \\
\hline
\end{tabular}




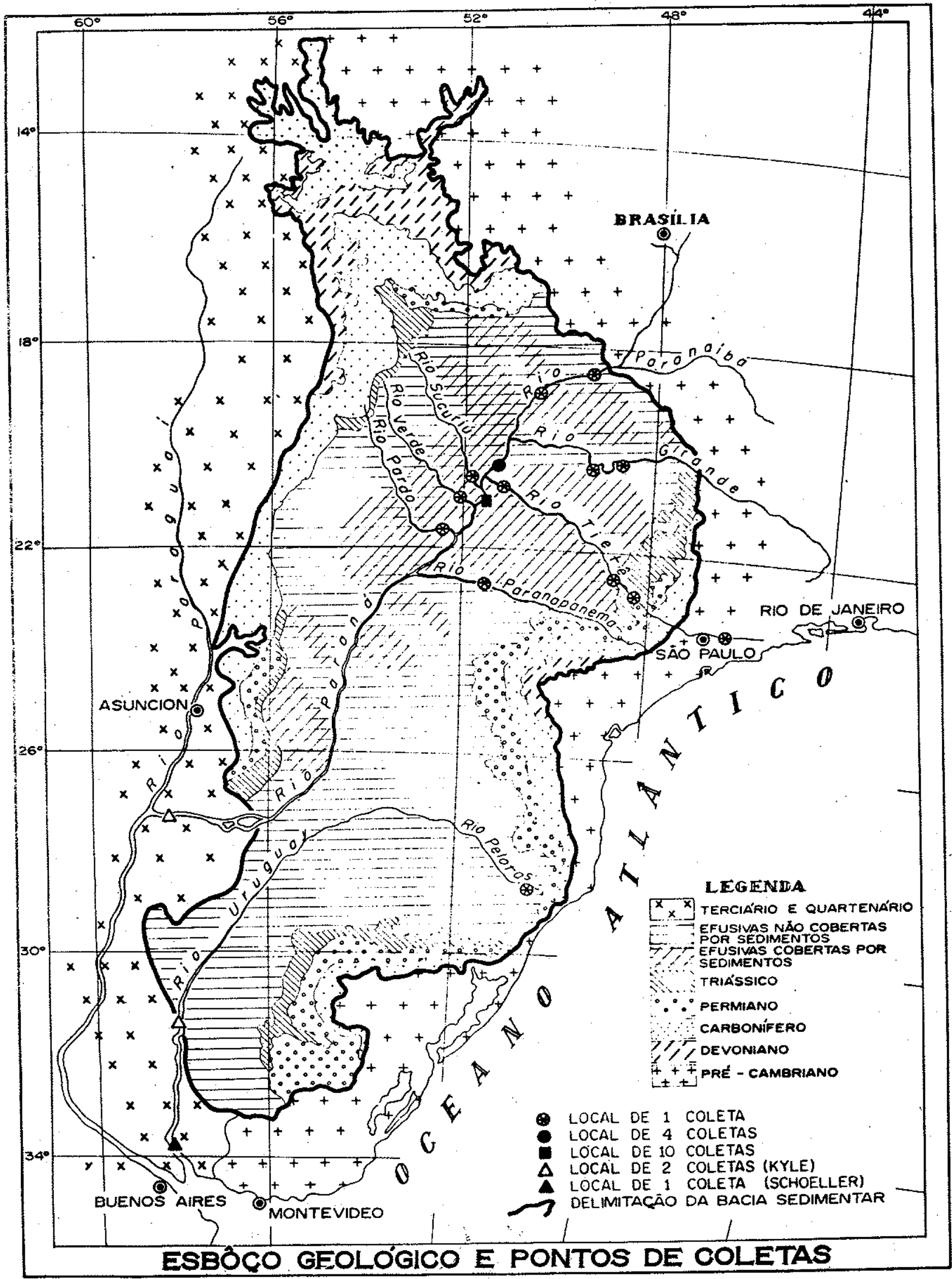

Figura 2 -'Esbôço geológico (modificado de Leinz, 1937 e D.N.P.M. - Divisão de Geologia e Mineralogia, 1960) e localização dos pontos de coleta. 
o conhecimento da composição química das rochas das áreas de drenagem ẻ de grande importância. Existe uma relação entre a composição das rochas e dos solos e os elementos que foram dissolvidos e levados em solu ção nas äguas dos rios.

Análise dos solos foi feita pela Comissão Nacio nal de Solos do Estado de São Paulo (1960).

Os solos da ärea drenada pelos rios estudados são diversificados, e os tipos mais importantes são:la tosois (origem variada, a partir de basalto e arenito, como tambêm de granito e gnaisse) e solos podzolizados (originados de arenitos calcíferos, argilitos e folhe lhos, como tambëm de granitos e gnaisses).

Os solos drenados pelos rios Paranaiba, Grande, Tietê, Paranapanema, Sucuriú, Verde, Pardo, Paraná e Pelotas e seus afluentes, são principalmente terras ro xas (estruturada e legítima), proveniente de alteração de basaltos e secundàriamente latosol vermelho escuro (proveniente do arenito Bauru).

Os rios Grande, Tietê e Paranapanema numa peque na parte, drenam área com solos podzolizados e podzol, proveniente de rochas cristalinas e sedimentos como arenitos, argilitos, folhelhos, etc.

As análises químicas dêstes solos mostraram,que a terra roxa tem concentração alta em óxido de ferro e de alumínio (em ordem decrescente) e baixa em óxido de silício.

o latosol vermelho amarelo tem teor alto em sí lica, óxido de alumínio e de ferro ( em ordem decres cente). 
ä - Clima

Para o conhecimento do clima da bacia do Rio da Prata è de grande importância o estudo das chuvas, sobretudo sua repartição na área, pois suas modifica ções estabelecem as nuances entre os diferentes tipos climáticos.

São considerados climas úmidos, aquêles onde a pluviosidade oscila entre 1000 a $2000 \mathrm{~mm} / \mathrm{ano}$, com uma repartição mais ou menos constante ( $f$, segundo a clas sificação de Koeppen). Na ărea estudada, não existe, pròpriamente estação sêca. 0 clima è caracterizado por uma sucessão de meses tropicais e de meses tempera dos (mais ou menos frios) e depende da relação de va riação entre os mesmos.

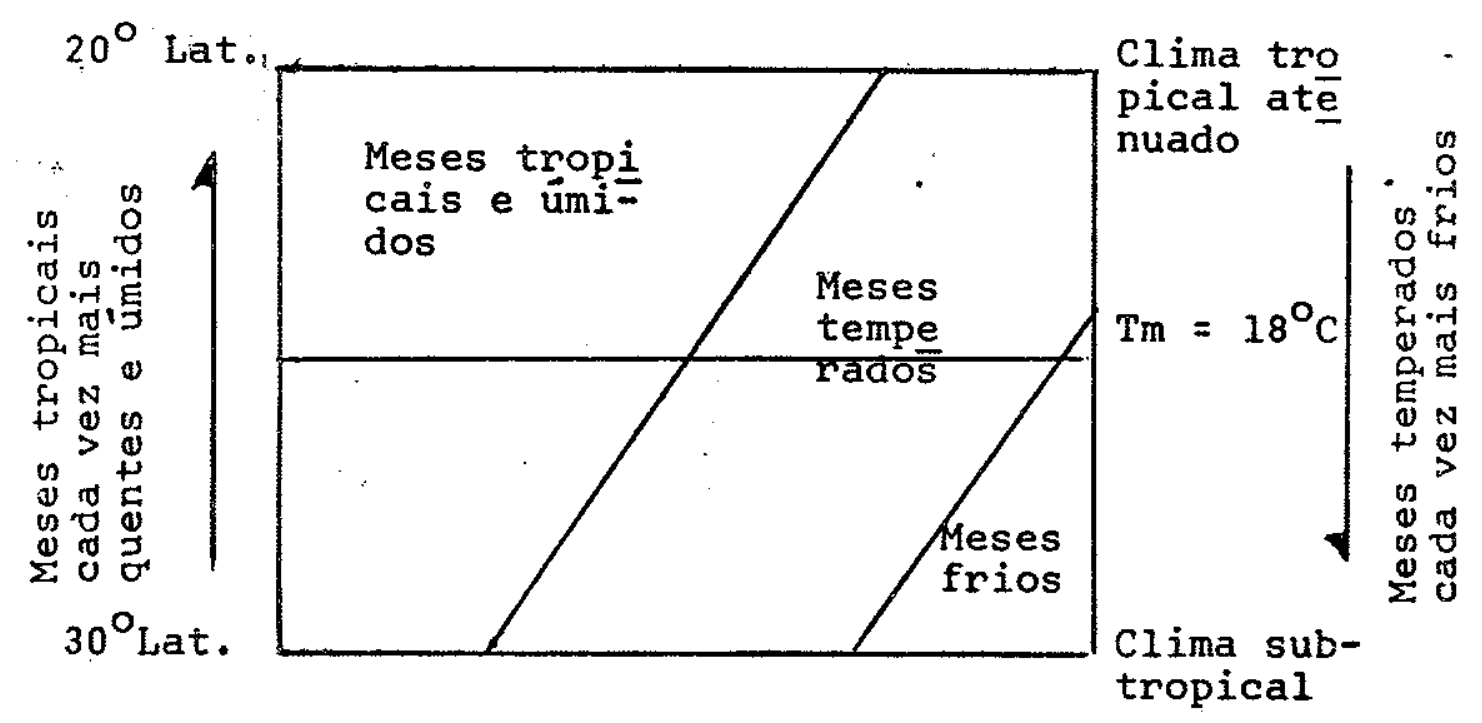

F́igura 3 - Esquema da repartição climática mensal no Sul do Brasil (Pedro, Melfi, Queiroz, 1970). 
Desta forma, no norte, o clima a do tipo tropical com temperatura mëdia anual de $20^{\circ} \mathrm{C}$ e amplitude térmica da ordem de $5^{\circ} \mathrm{C}$, entre 0 mês mais quente e $\circ$ mais frio. 0 nümero de meses quentes e ümidos ê da or dem de 7 e 8 tratando-se portanto de um clima tropical atenuado.

A medida que caminhamos para o sul da bacia on de as latitudes e as altitudes são mais elevadas, a tem peratura média desce sensivelmente para cêrca de $15^{\circ} \bar{C}$, e a amplitude aumenta, atingindo valôres de até $11^{\circ} \mathrm{C}$. o clima torna-se subtropical. 0 número de meses tro picais é da ordem de 3 a 6 meses, sendo o restante do ano constituido por meses temperados.

$\mathrm{Na}$ Figura 4, mostramos a precipitação média anual na bacia do rio da Prata. 
$-17-$

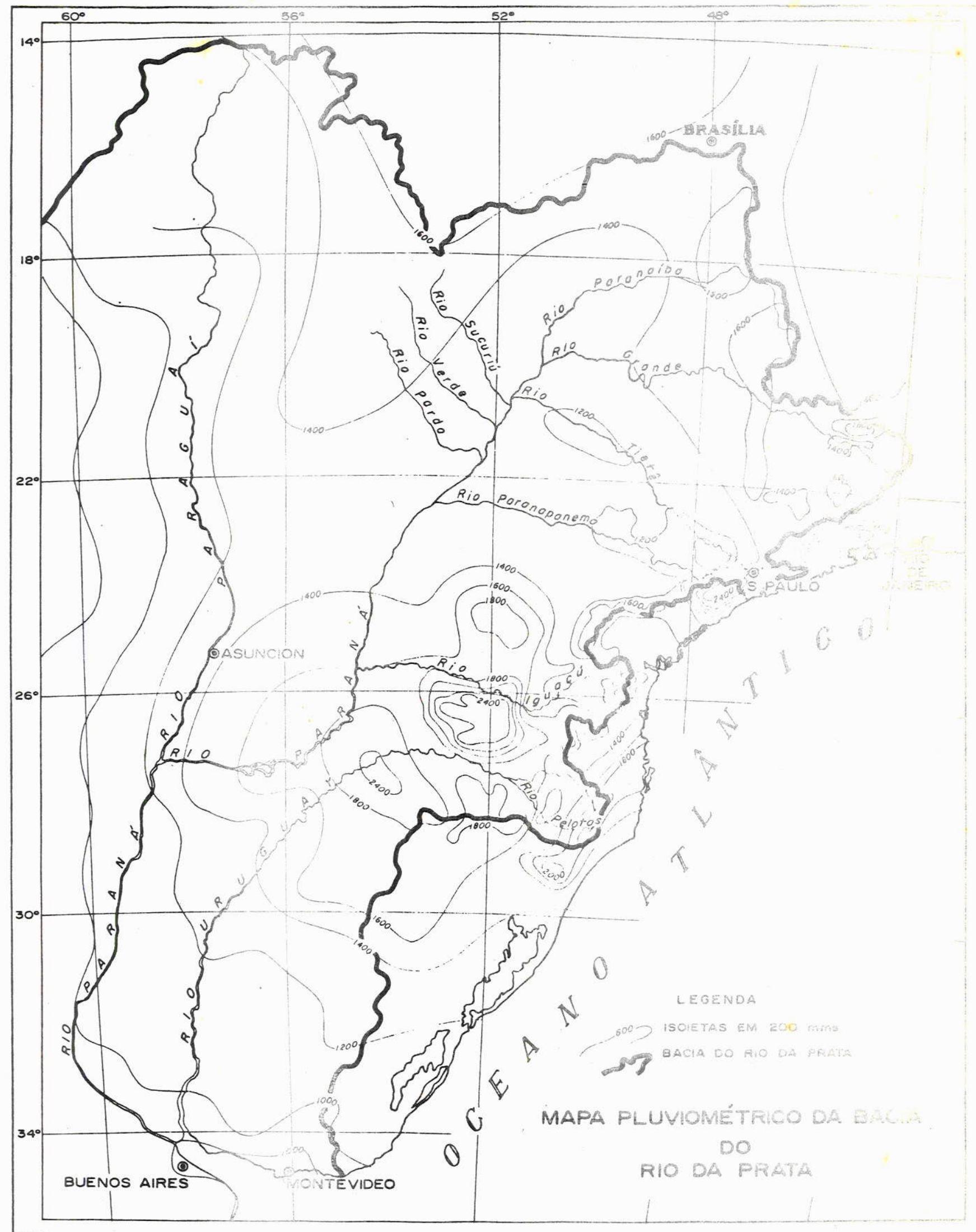

Figura 4 - Mapa de precipitação média anual da bacia do rio da Prata (seg. Publicação da Organização dos Estados Americanos, 1969). 
III. MATERIAIS E METODOS DE ESTUDO

a - Coleta

Sempre que possivel, o local de coleta das amostras, foi escolhido de acôrdo com a variação da li tologia. Nas áreas de litologia uniforme, a amostragem foi feita nas proximidades da foz do rio. Tôdas as amostragens foram realizadas na superficie da água dos rios.

As coletas foram feitas em garrafões de polie tileno de dez litros, prèviamente lavados com detergen te, ácido clorídrico e água destilada. Antes de preen cher o depósito, o mesmo foi lavado com a água do rio a ser coletada. Kleinkopf (1960) verificou que a água

não se contaminava e não mostrava variação na concentra ção dos elementos traços, mesmơ quando guardada por vá rios meses em garrafões de polietileno.

A água foi acidificada com ácido cloridrico para evitar precipitação, e devidamenté fechada para evitar oxidação dos seus compostos.

b - Análises

A análise dos elementos maiores foi feita por via úmida no Laboratório de Química do Departamento Na cional da Produção Mineral, no Rio de Janeiro. Algumas análises para sódio e potássio foram realizadas por fo tometria de chama. Os elementos traços foram analisa dos exclúsivamente pelo método espectrográfico cujo êrro oscila entre mais ou menos 15 a $20 \%$.

A espectrografia de emissão é um método rápi do para a análise de resíduos de água e permite a análí se simultânea de diversos elementos presentes nas águas 
dos rios. 0 método foi usado por Braidech e Emery (1935), Kleinkopf (1955, 1960) e Durum e Haffty (1960) entre outros, para anälises de resíduos de águas de rios.

1. Aparelhagem

0 aparelho utilizado foi o espectrögrafo "Hilger \& Watts, large quartz and glass", com prisma de quartzo de grande dispersão. Como fonte de excitação utilizou-se o arco de corrente contínua ( $V=220 \mathrm{~V})$ e intensidade de 8 ampères mantidos durante tôda a exposi ção. Foram usados eletrodos espectrogràficamente puros do "National Carbon Company", de $3 / 16$ polegadas, com cavidade cônica. Utilizou-se filme Kodak Kp $651-1$ posi tivo, processado com revelador D - I9b e fixador F - 5 . Para a determinação das concentrações dos elementos foi utilizado o densitômetro "ARL Spectroline Scanner" - Mo dêlo 22000 - 153. Para a pesagem das amostras a serem colocadas nos eletrodos foi utilizada a balança analíti ca de leitura direta.

2. Tẻcnicas Utilizadas

2.1. Filtragem - As águas foram filtradas com papel de filtro tipo "Whatman n: 42", para eliminar tô da a matéría em suspensão, em balão de vidro de um li tro lavado com detergente, ácido clorídrico, água desti lada e com a água filtrada do rio. No balão foi verifi cada a ausência de efeito Tyndall.

2.2. Secagem - A secagem em estufa, foi feita primeiro em "Becher" de pirex com temperatura ao redor de $200^{\circ} \mathrm{C}$ e depois os $200 \mathrm{~cm}^{3}$ restantes de água, em ca dinho de porcelana. 0 mesmo cuidado foi tomado relatí 
vo a lavagem, para evitar qualquer tipo de contaminação.

Metais na forma iônica reagem com a matéria or gânica formando complexos organo-metálicos solúveis em água, mas não dissociados. Dessa forma, è necessảrio eliminar a matéria orgânica, calcinando o residuo. $\left(\mathrm{T}=800^{\circ} \mathrm{C}\right)$

\subsection{Estudo espectrogräfico}

2.3.1. Padrões - Foram preparados padrões para quarenta elementos por Szikszay (1969). A intensi dade da linha de um composto depende das propriedades da fonte de excitação, das propriedades das linhas emi tidas e finalmente do nümero dos átomos presentes no arco.

$$
\text { Ia N } \quad \begin{aligned}
& I=\text { intensidade } \\
& N=\text { número de ätomos } \\
& \quad C=\text { concentração } .
\end{aligned}
$$

Fixadas as condições, $\mathrm{N}$ depende de $\mathrm{C}$.

$I \propto C$

Variando $C$, pelo uso de padrões de concentrações conhecidas, os valôres correspondentes de I podem ser conhecidos. Se o log das duas variáveis é relacio nado gràficamente, êste gräfico resultante denomina-se "curva de trabalho".

2.3.2. Preparação dos eletrodos das amos tras - o resíduo calcinado foi misturado com pó de grá fita ( 1 parte do resíduo para 2 partes de pó de grafita). - 0 pó de grafita é utilizado para manter a queima no ar 
co uniforme e evitar volatilização seletiva.

Foram pesados $15 \mathrm{mg}$ dessa mistura para cada ele trodo. O tempo de exposição foi de $2^{\circ} 30^{\prime \prime}$, com a intens dade da corrente igual a 8 ampères. 0 intervalo de com primento de onda utilizado varia entre 2480 - $3680 \AA$. A distância entre os eletrodos $(4 \mathrm{~mm}$ ) foi mantida durante todo o periodo de excitação, sendo a abertura da fenda $0,013 \mathrm{~m}$. O tempo de revelação e fixação do filme foi de $3^{\prime} 30$ ". As condições de exposição e revelação dos pa drões, bem como a preparação dos eletrodos foram idênti cas às condições para as amostras desconhecidas.

A exposição das amostras desconhecidas foi fei ta com três eletrodos para cada amostra. Depois da reve lação, fixação e secagem, o filme foi examinado com 0 densitômetro. A leitura no densitômetro ( $\%$ de transmis são) è calculada em têrmos de intensidade e os valôres para as percentagens das concentrações das amostras são lidos nas curvas de trabalho. Os resultados podem apre sentar um êrro de mais ou menos de 15 a 20\%.

As linhas de comprimento de onda utilizadas pa . ra a anålise dos elementos encontram-se na Tabela 2.

\section{TABELA 2}

Linhas de comprimento de onda utilizadas

$\begin{array}{llllll}\text { B } & 2.497,73 & \AA & \text { Al } 3.082,15 & \AA \\ \text { P } & 2.553,28 & \text { " } & \text { V } 3.185,39 & " \\ \text { Mn } & 2.605,68 & \text { " } & \text { Cu } 3.247,54 & " \\ \text { Ti } & 2.948,25 & \text { " } & \text { Co } 3.405,12 & " \\ \text { Fe } & 3.020,64 & \text { N } & \text { Ni } 3.414,76 & " \\ \text { Bi } & 3.067,72 & & & \end{array}$


IV. RESULTADOS E DISCUSSÃO

a - Resultados gerais dos rios estudados.

A composição da água de um rio representa a mé dia ponderada da composição química de todos os seus afluentes, sendo influenciada pelos materiais trazidos pelas águas das chuvas e águas subterrâneas além da contaminação provocada em zonas de grande concentração humana (cidades e áreas industriais). A composição química das águas de pequenos rios reflete mais as con dições locais, e portanto pode apresentar grandes difé renças em sua composição. As composições químicas das águas dos grandes rios são menos variáveis e são seme lhantes quando comparadas.

Em seguida, apresentamos os dados referentes à composição dos rios estudados, separadamente e em con junto, mediante diversos tipos de comparações.

Compara-se: I) Resultados de coletas de dois rios (Verde e Pardo), próximos $( \pm 80 \mathrm{~km}$ ), de litologias semelhantes efetuadas no mesmo dia e estação.

2) Resultados de amostras coletá das no rio Paraná, no mesmo dia, e em locais próximos (3, 2 e $1 \mathrm{~km}$ acima de Ilha Solteira).

3) Resultados de coletas feitas no rio Paraná, no mesmo local, mas em estações e anos diferentes (Ilha Solteira).

4) Resultados de coletas feitas no rio Paraná, no mesmo local (Jupiä), durante um ano em estações diferentes. 
5) Resultados de coletas feitas no rio Paraná, no mesmo local (Jupiā) dia e mês, portanto mesma estação, porém en anos diferentes.

6) Resultados de coletas feitas em dois Iugares diferentes (Ilha Solteira e Jupiā) do rio Paraná, no mesmo dia, mês e ano, portanto mesma estação.

Julgamos oportuno apresentar separadamente os resultados relativos aos rios das margens direita e es querda, visto que as condições geológicas de ambas as margens do rio Paranā serem sensivelmente diferentes.

1. Rios da margem direita do rio Paraná.

1.1. Rio Sucuriú - A coleta das águas do rio Sucuriú (Figura 2) foi realizada na primavera, próximo à ponte, a $1 \mathrm{~km}$ antes do rio desaguar na reprêsa de Uru bupungá. As rochas que o rio Sucuriü atravessa são pre dominantemente basaltos e arenitos.

Os resultados das anāilises das ágúas dêste rio estão apresentados nas Tabelas 3 e 4 . 
TABELA 3

Elementos maiores e menores dosados nas águas do rio Sucuriú (mg/l e percentagem do residuo)

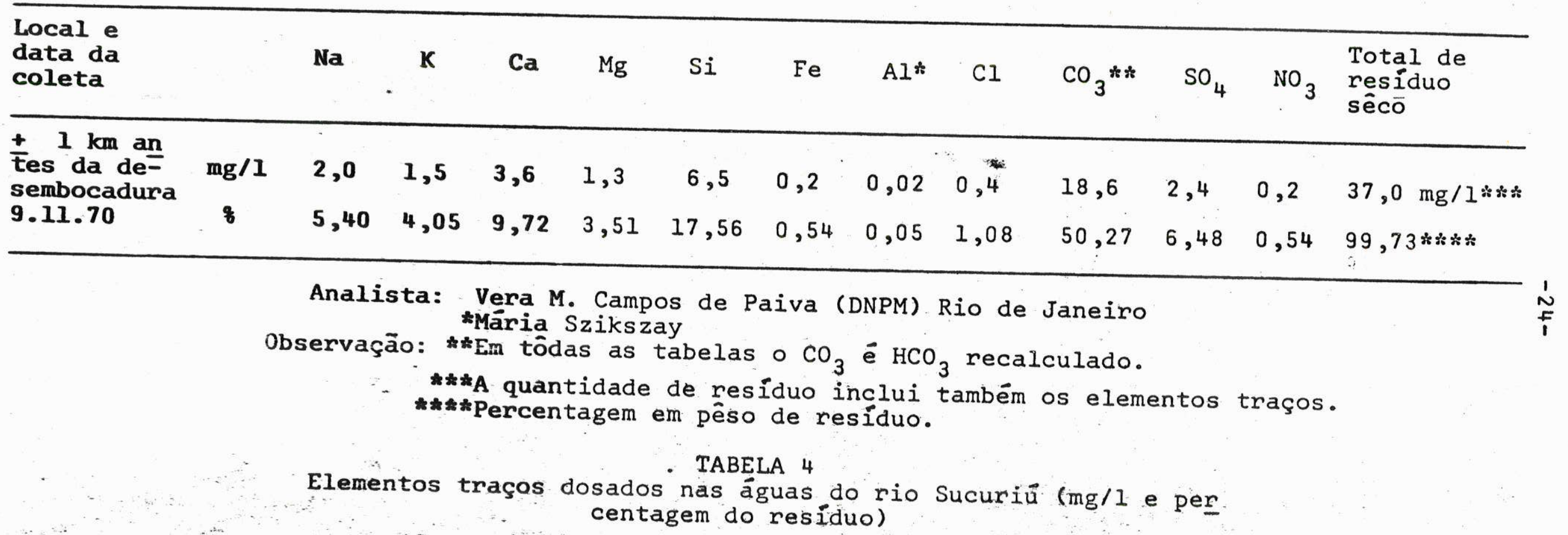

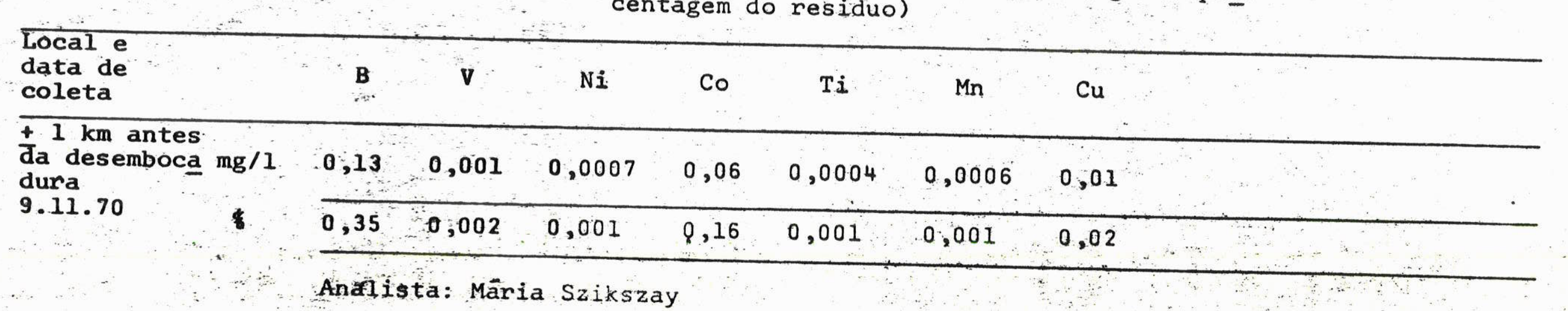


TABELA 5

Elementos maiores e menorés dosados nas águas do rio Verde (mg/l e percentagem do resíduo)

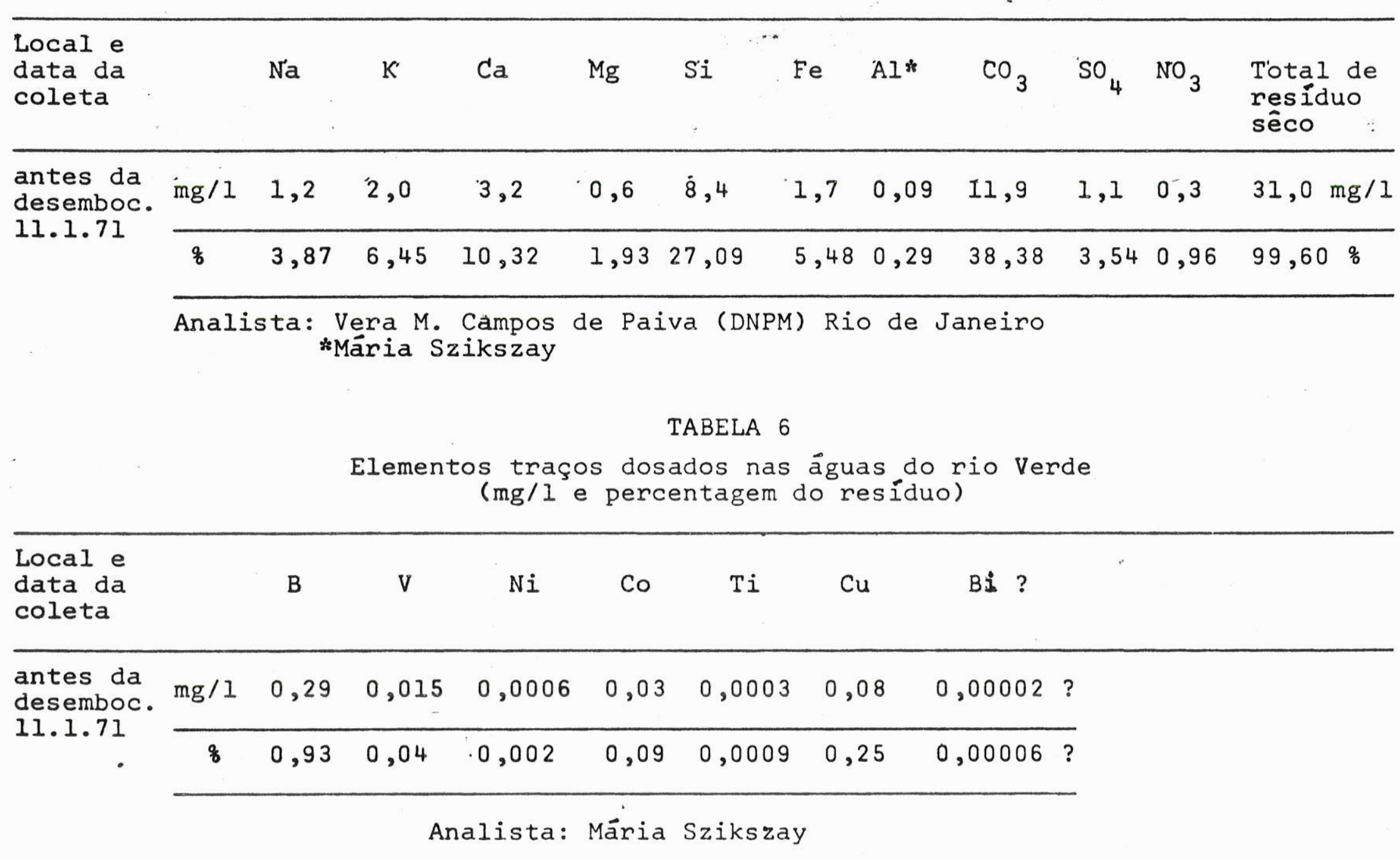

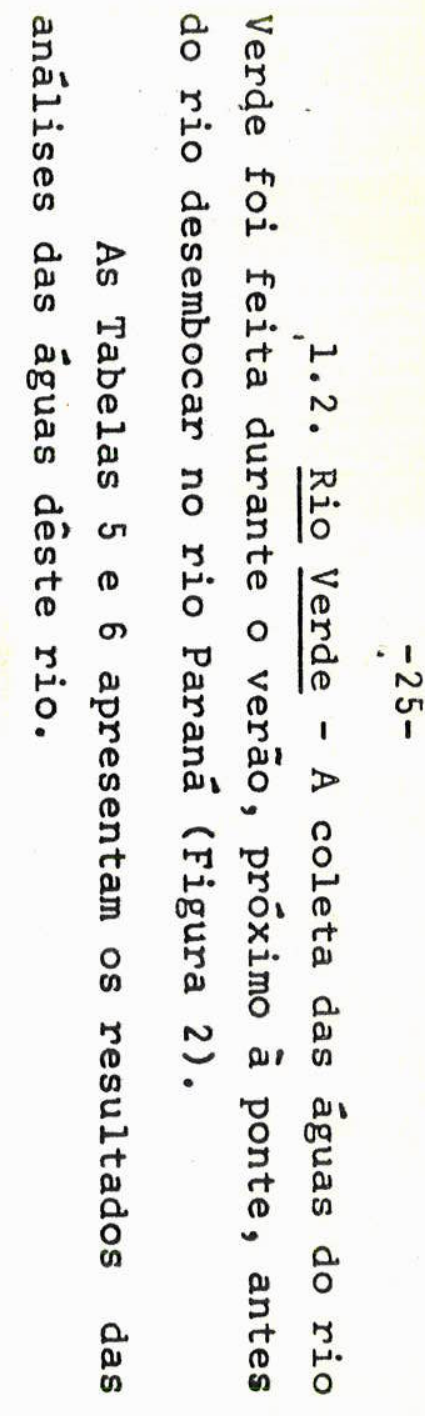


TABELA 7

Elementos maiores e menores dosados nas águas do rio Pardo (mg/l e percentagem do resíduo)

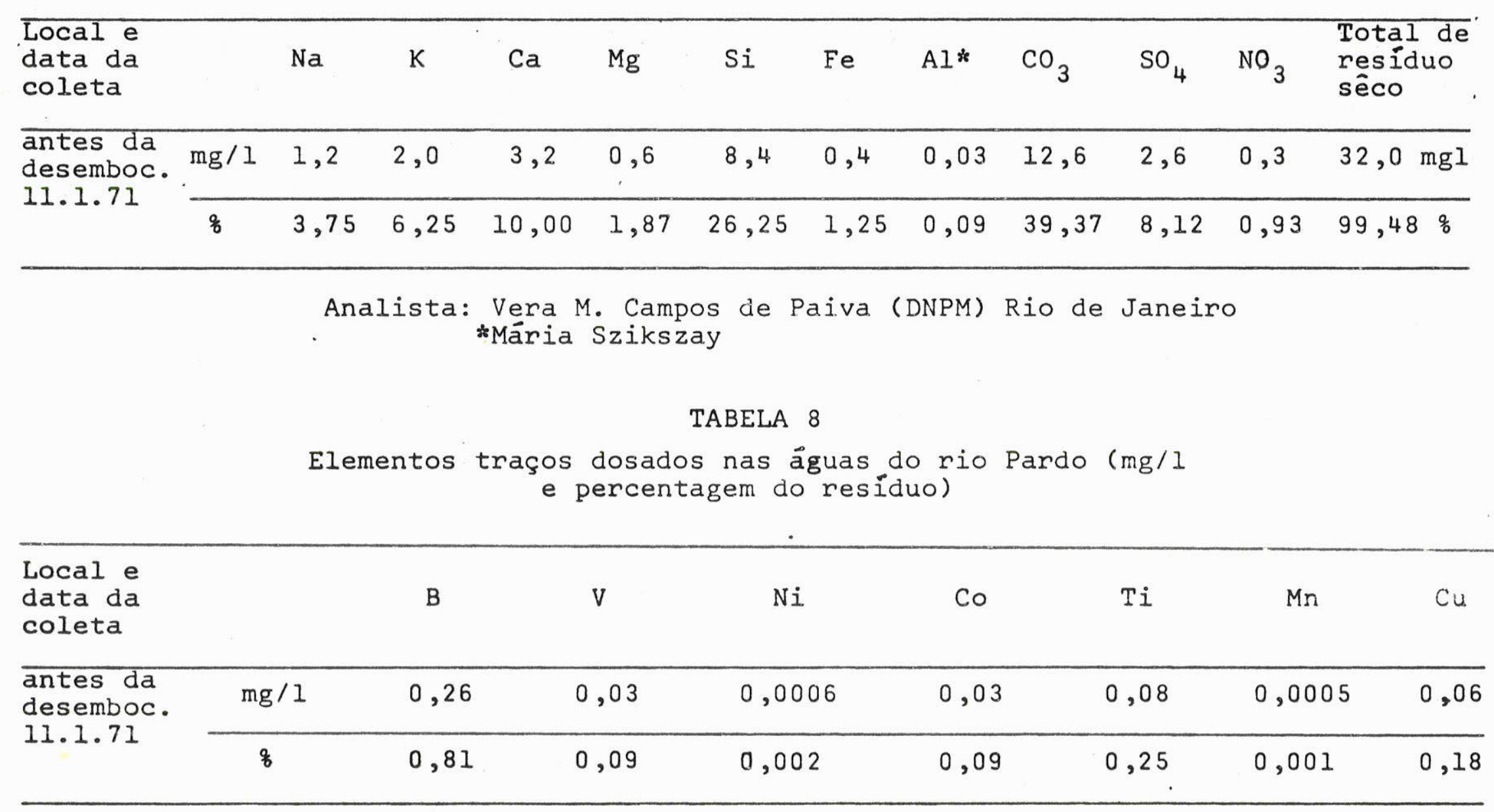

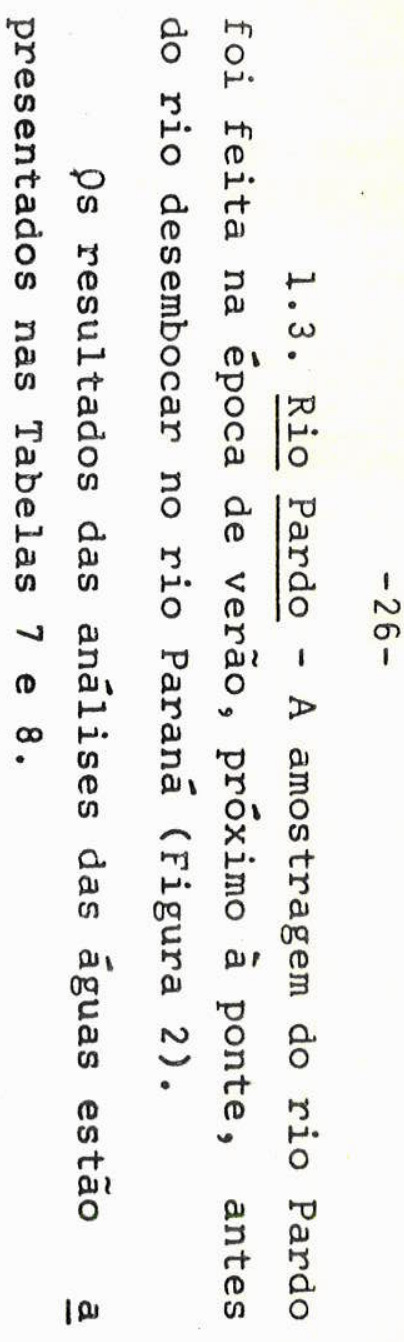

Analista: Mária Szikszay . 
Durante o ciclo de intemperismo o sódio e $\circ$ po tássio têm cursos diferentes. O potássio entra em solu ção primeiro mas não fica dissolvido, sendo adsorvido pela argila. Uma parte do magnésio também é incorpora da nos sedimentos.

As razões $\mathrm{Na} / \mathrm{K}$ e $\mathrm{Ca} / \mathrm{Mg}$ são as seguintes durante o ciclo dos elementos (Rankama e Sahama, 1949):

$\begin{array}{lrr} & \mathrm{Na} / \mathrm{K} & \mathrm{Ca} / \mathrm{Mg} \\ & 1,09 & 1,73 \\ \text { Rochas Igneas } & 2,73 & 5,98 \\ \text { Agua dos rios } & 27,84 & 0,31 \\ \text { Agua do mar } & 0,36 & 1,50\end{array}$

Para situar a composição química dos rios estuda dos comparamos as razões $\mathrm{Na} / \mathrm{K}$ e $\mathrm{Ca} / \mathrm{Mg}$ com os valôres de Rankama e Sahama:

$\mathrm{Na} / \mathrm{K}$

Rio Sucuriú
Rio Verde
Rio Pardo

Rio Sucuriú

Rio Pardo
$\mathrm{Ca} / \mathrm{Mg}$

$$
\begin{aligned}
& 3,6 / 1,3=2,76 \\
& 3,2 / 0,6=5,33 \\
& 3,2 / 0,6=5,33
\end{aligned}
$$

A razão $\mathrm{Na} / \mathrm{K}$ encontrada nas águas dos três rios não se aproxima da média padrão, observando-se uma con centração alta de potássio. 0 mesmo é observado para a razão $\mathrm{Ca} / \mathrm{Mg}$ do rio Sucuriú. Já para os rios Verde e Pardo esta razão aproxima-se da média padrão. 
Observa-se uma semelhança, tanto na composição das águas dos rios Verde e Pardo como na quantidade de material em solução, sendo $31,0 \mathrm{mg} / \mathrm{l}$ para o rio verde e 32,0 mg/l para o rio Pardo. Tanto o rio Verde como - Pardo e seus afluentes, drenam áreas com litologias semelhantes (basaltos e arenitos), e a amostragem foi efetuada no mesmo dia.

A comparação dos resultados das análises dos rios Verde e Pardo estão representadas nos gráficos das Figuras 5 e 6 .

Observando a Figura 5 nota-se a semelhança em composição dos dois rios com exceção do ferro e sulfato. A explicação mais provável para esta semelhança talvez seja a litologia análoga.

A Figura 6 mostra que as concentrações de coba] to e níquel são semelhantes nos dois rios. Nota-se uma concentração maior de vanádio e uma concentração muito grande de titânio no rio Pardo. o boro, alumínio e co bre estão em concentrações maiores no rio Verde.

$0 \mathrm{pH}$ dos dois rios também é semelhante, sendo 6,9 o do rio Verde e 6,4 o do rio Pardo. 
$-29-$

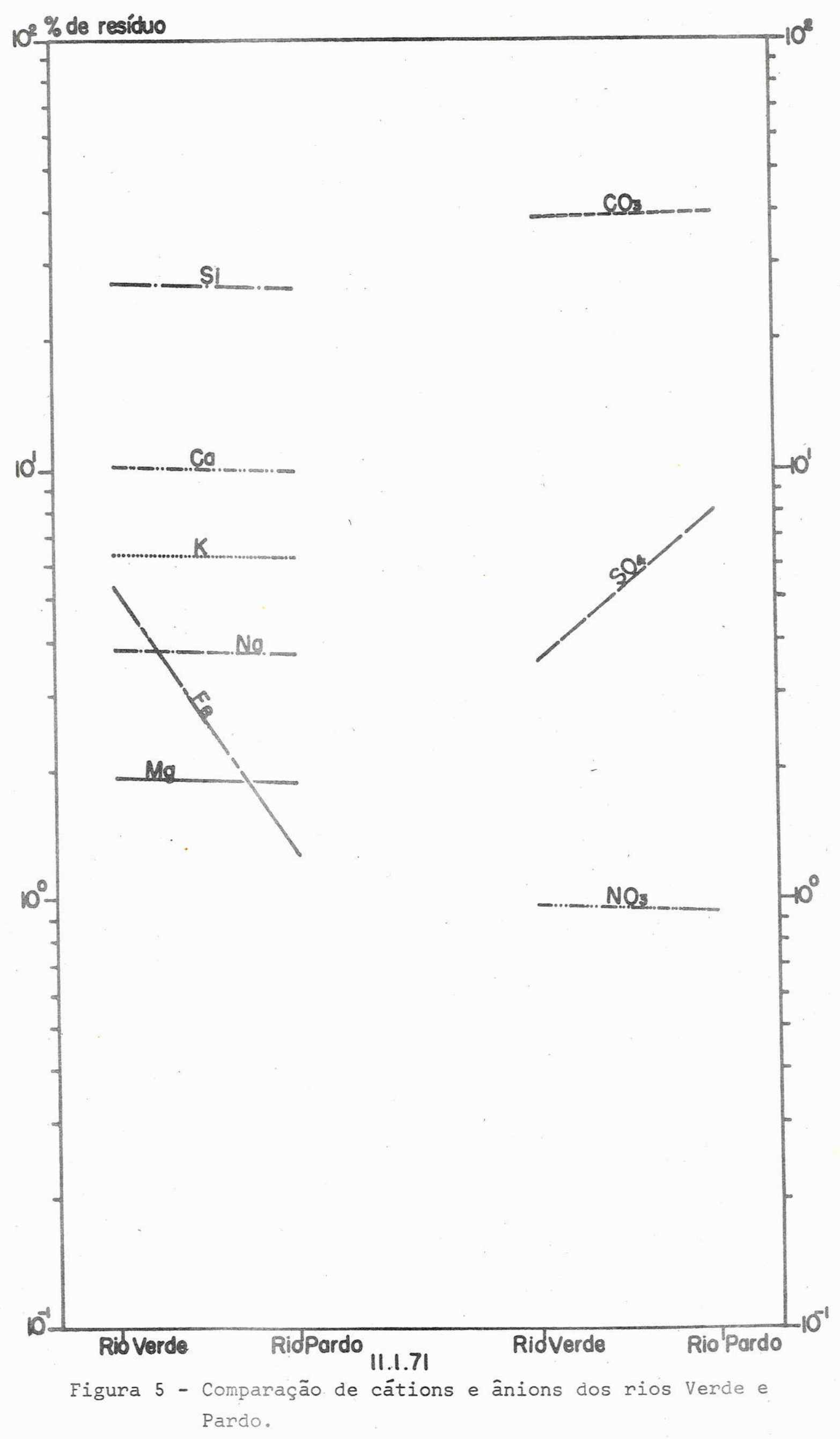


$-30-$

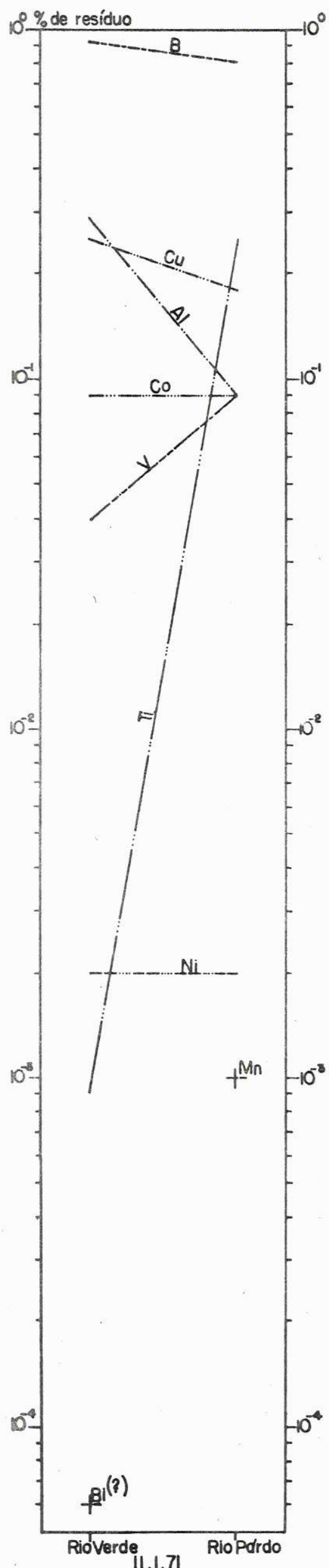

Figura 6 - Comparação dos elementos traços dos rios Verde e Pardo, 
2. Rios da margem esquerda do rio Paranä.

2.1. Rio Tietê - As coletas de água do rio Tietê (Figura 2) foram feitas em quatro locais: 1) a 3 quilômetros aproximadamente acima da cidade de Mogi das Cruzes, na primavera; 2) perto de Anhembi; 3) em Barra Bonita (acima da barragem), no inverno; 4) perto da desembocadura do rio, também na primavera.

Nas Tabelas 9 e 10 apresentamos os resultados das análises das amostras coletadas nos quatro lugares acima mencionados.

$\begin{array}{lrr} & \mathrm{Na} / \mathrm{K} & \mathrm{Ca} / \mathrm{Mg} \\ \text { Mogi das Cruzes } & 1,6 / 1,56=1,02 & 1,4 / 1,7=0,82 \\ \text { Anhembi } & 7,2 / 0,1 ?=72 ? ? & 9,4 / 3,8=2,42 \\ \text { Barra Bonita } & 4,2 / 3,7=1,13 & 4,6 / 3,9=1,17 \\ \text { Desembocadura } & 5,0 / 2,7=1,85 & 6,4 / 1,3=4,92 \\ & & \end{array}$
fora da média padrão. A razão $\mathrm{Ca} / \mathrm{Mg}$ tambëm não corres ponde a média padrão, exceto na desembocadura, onde os valôres são próximos.

A quantidade de material em solução aumenta no curso do rio, o que é de se esperar. Sòmente a quanti dade de material em solução em Anhembi apresenta dados muito fora do esperado.

Observa-se que existe uma variação de todos os elementos de um local de coleta para outro, sendo que os carbonatos mostram uma tendência de aumento ao lon go do curso do rio.

Nota-se um aumento considerável na concentra ção do boro a partir de Anhembi, o que pode ser expli cado pelo fato do rio Tietê, após esta localidade,atra 
TABELA 9

Elementos maiores e menores dosados nas águas do chia Tietê (mg/l e percentagem do residuo)

\begin{tabular}{|c|c|c|c|c|c|c|c|c|c|c|c|c|c|}
\hline $\begin{array}{l}\text { Local e } \\
\text { data da } \\
\text { coleta }\end{array}$ & ? & $\mathrm{Na}$ & K & $\mathrm{Ca}$ & $\mathrm{Mg}$ & $\mathrm{Si}$ & $\mathrm{Fe}$ & Al & $\mathrm{ClCl}$ & $\mathrm{CO}_{3}$ & $\mathrm{SO}_{4}$ & $\mathrm{NO}_{3}$ & $\begin{array}{l}\text { Total de } \\
\text { residuo. } \\
\text { sêco }\end{array}$ \\
\hline \multirow[t]{2}{*}{$\begin{array}{l}\text { Mogi das } \\
\text { Cruzes } \\
20.11 .66\end{array}$} & $\mathrm{mg} / \mathrm{I}$ & $1,6 *$ & $1,56 *$ & 1,4 & 1,7 & 1,4 & 0,1 & $0,008 * *$ & 1,51 & 3,7 & 2,0 & - & $15,0 \mathrm{mg} \chi$ \\
\hline & $q$ & 10,66 & 10,40 & 9,33 & 11,33 & 9,33 & 0,66 & 0,05 & 10,00 & 24,66 & 13,33 & - & $99,90 \%$ \\
\hline Anhembi & $\mathrm{mg} / \mathrm{I}$ & 7,2 & 0,1 & 9,4 & 3,8 & 9,3 & 1,6 & $0,0001 * *$ & 1,5 & 26,0 & 8,2 & 12,0 & $80,0 \mathrm{mgl}$ \\
\hline 12.6 .70 & $q$ & 9,00 & 0,12 & 11,75 & 4,75 & 11,62 & 2,0 & 0,80 & 0,87 & 32,50 & 10,25 & 15,0 & $99,50 \%$ \\
\hline \multirow{2}{*}{$\begin{array}{l}\text { Barra Bo } \\
\text { nita } \\
30.7 .67\end{array}$} & mg / I & $4,2 *$ & $3,7 *$ & 4,6 & 3,9 & 4,4 & 0,8 & 0,5 & 4,2 & 15,0 & 1,7 & - & $43,3 \mathrm{mgl}$ \\
\hline & 8 & 9,69 & 8,52 & 10,62 & 9,00 & 10,16 & 1,84 & 1,15 & 9,69 & 34,66 & 3,92 & - & $99,53 \%$ \\
\hline \multirow{2}{*}{$\begin{array}{l}\text { Desembo } \\
\text { cadura } \\
9.11 .70\end{array}$} & mg / I & 5,0 & 2,7 & $6,4 i$ & 1,3 & $.7,5$ & 1,2 & $0,01 * *$ & 2,4 & 26,0 & 5,4 & 0,7 & $59,0 \mathrm{mgl}$ \\
\hline & $q$ & 8,47 & 4,57 & $10,8 \mathrm{H}$ & 2,20 & 12,71 & 2,03 & 0,01 & 4,06 & 44,06 & 9,15 & 1,18 & $99,65 \%$ \\
\hline
\end{tabular}

Analistas: Cecilia M.Coelhol e Vera M. Campos de Paiva (DNPM) Rio de Janeiro. *Cláudio Comerlartti, Centro de Pesquisas Geocronológicas, São Paulo. * Märia Szikszayzaty

observação: Os dados de Mogriodas Cruzes e Barra Bonita são completados com dados de trabalhos toriones (Szikszay, 1969)。 
TABELA 10

Elementos traços dosados nas äguas do rio Tieté (mg/l e percentagem do residuo)

\begin{tabular}{|c|c|c|c|c|c|c|c|c|}
\hline $\begin{array}{l}\text { Local e } \\
\text { data da } \\
\text { coleta }\end{array}$ & & B & V & $\mathrm{Ni}$ & Co & $T i$ & $\mathrm{Mn}$ & $\mathrm{Cu}$ \\
\hline \multirow{2}{*}{$\begin{array}{l}\text { Mogi das } \\
\text { Cruzes } \\
20.11 .66\end{array}$} & $\mathrm{mg} / \mathrm{l}$ & $\quad 0,007$ & 0,006 & 0,0007 & 0,001 & 0,01 & - & 0,0007 \\
\hline & 8 & 0,04 & 0,04 & 0,004 & 0,006 & 0,06 & - & 0,004 \\
\hline Anhembi & $\mathrm{mg} / \mathrm{I}$ & 0,4 & 0,08 & - & 0,03 & 0,08 & 0,05 & 0,04 \\
\hline 12.6 .70 & $\%$ & 0,50 & 0,10 & - & 0,03 & 0,10 & 0,06 & 0,05 \\
\hline \multirow{2}{*}{$\begin{array}{l}\text { Barra } \\
\text { Bonita } \\
30.7 .67\end{array}$} & $\mathrm{mg} / \mathrm{I}$ & 0,26 & 0,008 & - & 0,01 & 0,004 & 0,008 & 0,008 \\
\hline & 8 & 0,60 & $0,01^{\circ}$ & - & 0,02 & 0,009 & 0,01 & 0,01 \\
\hline \multirow{2}{*}{$\begin{array}{l}\text { Desembo } \\
\text { cadura } \\
9.11 .70\end{array}$} & $\mathrm{mg} / \mathrm{I}$ & 0,06 & - & 0,012 & 0,0002 & - & 0,01 & 0,04 \\
\hline & 8 & 0,10 & - & 0,20 & 0,0003 & - & 0,01 & 0,06 \\
\hline
\end{tabular}

Analista: Märia Szikszay 
vessar sedimentos da Formação Irati, que segundo Amaral (1967), são ricos em boro. Amaral encontrou valôres de $50 \mathrm{ppm}$ de boro nos folhelhos, valor êste muito acima do normal para sedimentos que é de 3 ppm (Rankama e Sahama, 1949).

O alumínio varia para cada local amostrado. 0 níquel é observado em pequena quantidade próximo à Mo gi das Cruzes, depois não é detectável, aparecendo no vamente antes do rio entrar na reprêsa de Urubupungá, com concentração bastante aumentada. Cobalto, titânio e vanádio variam ao longo do curso do rio. De acôrdo com Kharkar et al. (1968), a montmorillonita e a illi ta adsorvem $90 \%$ do cobalto presente em solução nas águas dos rios. O hidróxido de ferro, recentemente pre cipitado adsorve $95 \%$ de cobalto e o dióxido de manganés $20 \%$ de cobalto. 0 cobre varia de um lọcal para outro. 0 manganês aparece, sòmente depois do segundo local da coleta, ou seja, Anhembi.

Acreditamos que, interpretações relativas as va riações das concentrações dos elementos ao longo do rio Tietê, ainda são prematuras, pois os resultados obtidos, embora sugestivos, são em número reduzido, sendo neces sário um estudo mais amplo para a formulação de qual quer hipótese. 
2.2. Rio Paranapanema - 0 rio Paranapanema foi amostrado próximo a cidade de Porecatú (Figura 2) durante a primavera. As rochas da região são arenitos, siltitos, folhelhos, calcários, dolomitos e predominan temente basaltos.

Os resultados das análises das águas do rio Pa ranapanema estão apresentados nas Táblas 11 e 12 .

3. Rio Paraná e seus formadores.

3.1. Rio Paranaíba - As duas coletas ( Figu ra 2) das águas do rio Paranaíba foram feitas em Itum biara, no outono, e no Canal São Simão no inverno. Em Itumbiara, o rio Paranaíba atravessa basaltos, porém pode haver também a influência de rochas do embasamen to cristalino, onde seus afluentes se originam. No Ca nal de São Simão as rochas predominantes são basaltos.

Nas Tabelas 13 e 14 apresentamos os resultados dos elementos maiores, menores e elementos traços en contrados nas águas do rio Paranaíba, das amostras co letadas em Itumbiara e no Canal de São Simão. 
TABELA 11

Elementos maiores e menores dosados nas águas do rio Paranapanema (mg/I e percentagem do residuo)

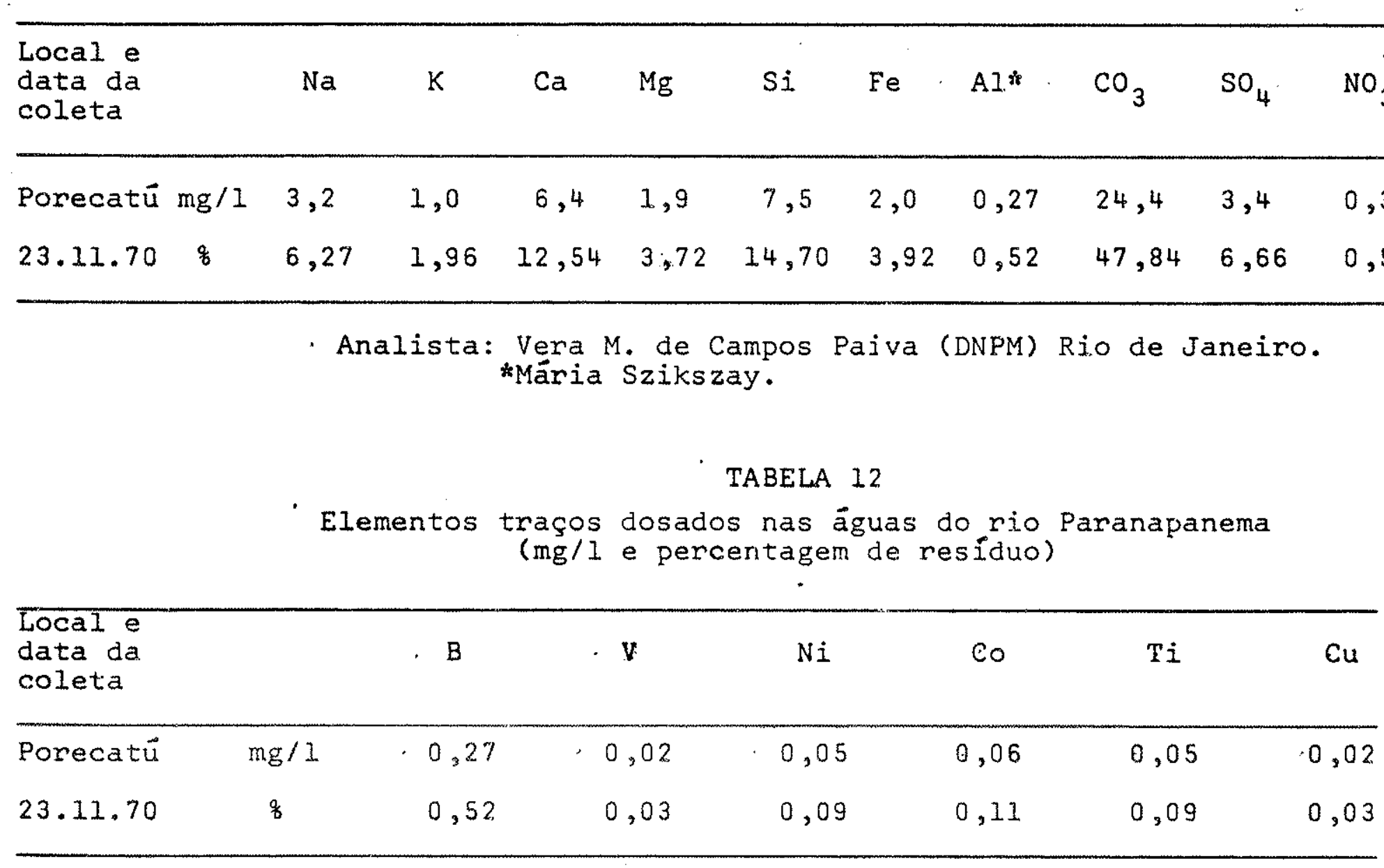

Analista: Märia Szikszay. 
TABELA 13

Elementos maiores e menores dosados nas águas do rio Paranaíba (mg/l e percentagem do residuo)

\begin{tabular}{|c|c|c|c|c|c|c|c|c|c|c|c|}
\hline $\begin{array}{l}\text { Local e } \\
\text { data da } \\
\text { coleta }\end{array}$ & & $\mathrm{Na} *$ & $\mathrm{~K}^{*}$ & $\mathrm{Ca}$ & $\mathrm{Mg}$ & Si & $\mathrm{Fe}$ & $\mathrm{A} I * *$ & $\mathrm{CO}_{3}$ & $\mathrm{SO}_{4}$ & $\begin{array}{l}\text { Total de } \\
\text { resíduo } \\
\text { sêco }\end{array}$ \\
\hline Itumbiara & $\mathrm{mg} / \mathrm{I}$ & 1,7 & 0,5 & 3,0 & 0,5 & 2,7 & 0,2 & $.0,009$ & 7,8 & 3,3 & $20,2 \mathrm{mg} / \mathrm{I}$ \\
\hline 24.4 .68 & $\%$ & 8,41 & 2,47 & 14,85 & 2,47 & 13,36 & 0,99 & 0,04 & 38,61 & 16,33 & $100,16 \%$ \\
\hline $\begin{array}{l}\text { Canal São } \\
\text { Simão }\end{array}$ & $\mathrm{mg} / \mathrm{I}$ & 0,2 & 0,7 & 5,3 & 3,6 & 3,2 & 0,3 & 0,01 & $1.8,9$ & 4,6 & $37,8 \mathrm{mg} / \mathrm{l}$ \\
\hline 9.8 .69 & $\%$ & 0,52 & 1,85 & 14,02 & 9,46 & 8,46 & 0,79 & 0,02 & 50,00 & 12,16 & $99,42 \%$ \\
\hline
\end{tabular}

Analistas: Cecilia M. Coelho e Vera M.Campos de Paiva (DNPM)Rio de Janeiro. *Cláudio Comerlatti, Centro de Pesquisas Geocronológicas, São Paulo. **Mária Szikszay

TABELA 14

Elementós traços dosados nas äguas do rio Paranaíba (mg/l e percentagem do resíduo)

\begin{tabular}{|c|c|c|c|c|c|c|c|c|}
\hline $\begin{array}{l}\text { Local e data. } \\
\text { da coleta }\end{array}$ & & B & v & $\mathrm{Ni}$ & Co & $\mathrm{Ti}$ & $\mathrm{Cu}$ & \\
\hline Itumbiara & $\mathrm{mg} / \mathrm{l}$ & 0,48 & 0,0002 & 0,009 & 0,01 & 0,02 & 0,02 & \\
\hline 24.4 .68 & $\%$ & 2,37 & 0,009 & 0,04 . & 0,04 & 0,09 & 0,09 & \\
\hline $\begin{array}{l}\text { Canal São } \\
\text { Simão }\end{array}$ & $\mathrm{mg} / \mathrm{l}$ & 0,73 & 0,0002 & 0,01 & 0,02 & 0,03 & 0,03 & \\
\hline 9.8 .69 & $q$ & 1,93 & 0,008 & 0,02 & 0,05 & 0,07 & 0,07 & Analista: Märia Szikszay \\
\hline
\end{tabular}


Os valôres das razões $\mathrm{Na} / \mathrm{K}$ estão muito afastados dos valôres apresentados para a média padrão. A - razão $\mathrm{Ca} / \mathrm{Mg}$ em Itumbiara está próxima à média padrão, o que não ocorre no Canal de São Simão.

Como as coletas foram feitas em dois lugares e em estações diferentes, a comparação entre os dois resultą dos é impraticävel. Conforme era previsto, verificou-se, que a quantidade de material em solução é maior no inver no, e aumenta em direção a foz.

Observa-se pequena variação do $\mathrm{pH}$ nas duas esta ções e nos dois lugares de coleta, sendo 7,1 em Itumbia ra e 6,8 no Canal de São Simão.

3.2. Rio Grande - Duas coletas foram feitas no rio Grande. Uma na época do outono, mais ou menos perto de Frutal e outra na primavera, próximo a Icém (Figura 2). Nos dois locais de amostragem, as rochas aflorantes, são predominantemente basaltos. 0 rio Grande e seus afluen tes, antes dos locais de coleta, atravessam rochas do embasamento cristalino.

As Tabelas 15 e 16 mostram os resultados das aná lises do rio Grande em Frutal e Icém. 
TABELA 15

Elementos maiores e menores dosados nas äguas do rio Grande (mg/l e percentagem do residuo)

\begin{tabular}{|c|c|c|c|c|c|c|c|c|c|c|c|c|c|}
\hline $\begin{array}{l}\text { Local e } \\
\text { data da } \\
\text { coleta }\end{array}$ & & $\mathrm{Na}$ & $\mathrm{K}$ & $\mathrm{Ca}$ & $\mathrm{Mg}$ & si & $\mathrm{Fe}$ & $\mathrm{A} I *$ & $\mathrm{Cl}$ & $\mathrm{CO}_{3}$ & $\mathrm{SO}_{4}$ & $\mathrm{NO}_{3}$ & $\begin{array}{l}\text { Total de } \\
\text { resíduo } \\
\text { sêco }\end{array}$ \\
\hline Frutal & $\mathrm{mg} / \mathrm{l}$ & $1,60 * *$ & $0,76 * *$ & 2,4 & 0,9 & 1,2 & 2,7 & 0,005 & 0,5 & 12,56 & - & - & $23,0 \mathrm{mg} / 1$ \\
\hline 25.4 .68 & 8 & 6,95 & 3,30 & 10,43 & 3,91 & 5,21 & 11,73 & 0,02 & 2,17 & 54,91 & - & - & 99,748 \\
\hline Icēm & $\mathrm{mg} / 1$ & 2,6 & 1,0 & 3,2 & 0,6 & 6,1 & 1,2 & 0,01 & 0,4 & 13,1 & 1,4 & 0,4 & $30,4 \mathrm{mg} / \mathrm{I}$ \\
\hline 2.11 .70 & 8 & 8,55 & 3,28 & 10,52 & 1,97 & 20,06 & 3,94 & 0,03 & 1,31 & 43,09 & 4,60 & 1,31 & $100,20 \%$ \\
\hline
\end{tabular}

Analistas: Elisabeth B.B.Winter e Vera M.Campos de Paiva (DNPM) Rio de Janeiro. *Mária Szikszay

\section{TABELA 16}

Elementos traços dosados nas äguas do rio Grande (mg/l e percentagem do residuo)

\begin{tabular}{|c|c|c|c|c|c|c|c|c|c|c|}
\hline $\begin{array}{l}\text { Local e data } \\
\text { da coleta }\end{array}$ & & B & $\mathrm{V}$ & $\mathrm{Ni}$ & Co & $\mathrm{Ti}$ & Mn & $\mathrm{Cu}$ & $\mathrm{Na} / \mathrm{K}$ & $\mathrm{Ca} / \mathrm{Mg}$ \\
\hline Frutal & $\mathrm{mg} / 1$ & 0,26 & 0,03 & 0,01 & 0,01 & 0,02 & $=$ & - & & \\
\hline 25.4 .68 & 8 & 1,13 & 0,13 & 0,04 & 0,04 & 0,08 & - & - & $1,60 / 0,76=2,10$ & $2,4 / 0,9=2,66$ \\
\hline Icém & $\mathrm{mg} / 1$ & 0,24 & 0,07 & 0,02 & 0,01 & 0,1 & 0,02 & 0,02 & & \\
\hline 2.11 .70 & $q$ & 0,78 & 0,23 & 0,06 & 0,03 & 0,32 & 0,06 & 0,06 & $2,6 / 1,0=2,6$ & $3,2 / 0$ \\
\hline
\end{tabular}

Analista: Märia Szikszay 
Como se observa a razão Na/K está próxima da média padrão nos dois pontos amostrados. A razão $\mathrm{Ca} / \mathrm{Mg}$ em Frutal não corresponde a média padrão, mas em Icẻm, êste valor está bem pröximo.

As duas coletas foram feitas em dois lugares diferentes, porém relativamente próximos ( $\pm 100 \mathrm{~km})$.

Nota-se uma certa variação na concentração do silício. A coleta em Icém foi feita após uma chuva. Tal fato foi suficiente para ocasionar um abaixamento do valor do $\mathrm{pH}$ para 5,1 , valor êste incomum para águas dos rios, mas comum para água da chuva. (Em Frutal o ph não foi medido.)

A quantidade total de resíduo de um lugar para outro variou pouco.

Observa-se variação de sódio e alumínio. Potăs sio e cálcio mantëm-se mais ou menos constantes. Existe menos magnésio e cloreto em Icém, como também menor quantidade de ferro e carbonato.

Em Icêm, observa-se uma maió concentração dos elementos traços titânio, níquel e vanádio, aparecimen to de manganês e cobre e uma concentração menor de bó ro e cobalto.

3.3. Rio Paranā - 0 rio Paraná forma-se pe Ia confluência de dois grandes rios que são os rios Grande e Paranaíba.

Foram feitas três coletas a montante de Ilha Solteira (Figura 2) no outono de 1968 e uma coleta na barragem de Ilha Solteira na primavera de 1970. As três primeiras coletas foram feitas no mesmo dia, após forte chliva. 
Em Jupiā, foram feitas 9 coletas pela Centrais Elétricas de São Paulo em 1964 durante o ano, e uma coleta na primavera de 1970.

Para fins comparativos foram utilizados também os dados obtidos por Kyle em 1878 em coletas realiza das a cinco milhas da desembocadura do rio Paraná, no rio La Plata.

Na Tabela 17 encontram-se os resultados das anälises do rio Paranā, coletadas acima de Ilha Soltei ra.

$\begin{array}{lcc} & \mathrm{Na} / \mathrm{K} & \mathrm{Ca} / \mathrm{Mg} \\ \text { Ilha Solteira } \pm 3 \mathrm{~km} & 6,1 / 5,4=1,12 & 4,8 / 3,3=1,45 \\ \text { IIha Solteira } \pm 2 \mathrm{~km} & 4,9 / 2,5=1,96 & 4,8 / 4,3=1,11 \\ \text { Ilha Solteira } \pm 1 \mathrm{~km} & 3,5 / 2,4=1,45 & 4,0 / 4,3=0,92 \\ \text { Ilha Solteira (acima) } & 0,8 / 0,6=1,33 & 5,8 / 1,6=3,67\end{array}$

Os valôres obtidos para as razões estão muito afastados dos valôres padrões. Observa-se de nôvo, va lôres altos para as concentraçōes de potássio e magné sio.

No gräfico da Figura 7 apresentamos os resulta dos das anālises do rio Paraná das coletas feitas em 6 de maio de 1968 . 
TABELA 17

Elementos maiores e menores dosados nas äguas do rio Paraná; Ilha Solteira (mg/l e percentagem do residuo)

\begin{tabular}{|c|c|c|c|c|c|c|c|c|c|c|c|c|c|}
\hline $\begin{array}{l}\text { ocal e } \\
\text { latada } \\
\text { oleta }\end{array}$ & & $\mathrm{Na}$ & $\mathrm{K}$ & $\mathrm{Ca}$ & $\mathrm{Mg}$ & Si & $\mathrm{Fe}$ & Al & $\mathrm{Cl}$ & $\mathrm{CO}_{3}$ & $\mathrm{SO}_{4}$ & $\mathrm{NO}_{3}$ & $\begin{array}{l}\text { Total de } \\
\text { resíduo } \\
\text { sêco }\end{array}$ \\
\hline $\begin{array}{l}3 \mathrm{~km} \text { aci } \\
\text { a Ilha Sôl }\end{array}$ & $\mathrm{mg} / \mathrm{l}$ & 6,1 & 5,4 & 4,8 & 3,3 & 3,1 & 0,94 & 0,58 & 3,0 & 20,9 & 29,0 & 0,1 & $77,7 \mathrm{mg} / 1 *$ \\
\hline $\begin{array}{l}\text { eira } \\
5.68\end{array}$ & 8 & 7,86 & 6,95 & 6,18 & 3,25 & 3,99 & 1,21 & 0,74 & 3,86 & 26,75 & 37,37 & 0,12 & $98,28 \&$ \\
\hline $\begin{array}{l}2 \mathrm{~km} \mathrm{aci} \\
\text { ia I.Solt. } \\
.5 .68\end{array}$ & $\begin{array}{c}\mathrm{mg} / \mathrm{I} \\
\mathrm{g}\end{array}$ & $\begin{array}{l}4,9 \\
5,90\end{array}$ & $\begin{array}{l}2,5 \\
3,01\end{array}$ & $\begin{array}{l}4,8 \\
5,78\end{array}$ & $\begin{array}{l}4,4 \\
5,18\end{array}$ & $\begin{array}{l}4,1 \\
4,93\end{array}$ & $\begin{array}{l}0,52 \\
0,62\end{array}$ & $\begin{array}{l}0,31 \\
0,37\end{array}$ & $\begin{array}{l}3,0 \\
3,61\end{array}$ & $\begin{array}{l}23,0 \\
27,71\end{array}$ & $\begin{array}{l}35,40 \\
42,65\end{array}$ & $\begin{array}{l}0,1 \\
0,12\end{array}$ & $\begin{array}{l}83,0 \mathrm{mg} / 1 * \\
99,88 \%\end{array}$ \\
\hline $\begin{array}{l}I \mathrm{~km} \mathrm{aCI} \\
\text { ia I.Solt. } \\
.5 .68\end{array}$ & $\begin{array}{l}\mathrm{mg} / \mathrm{I} \\
\mathrm{q}\end{array}$ & $\begin{array}{l}3,5 \\
4,86\end{array}$ & $\begin{array}{l}2,4 \\
3,33\end{array}$ & $\begin{array}{l}4,0 \\
5,55\end{array}$ & $\begin{array}{l}4,4 \\
5,97\end{array}$ & $\begin{array}{l}1,8 \\
2,50\end{array}$ & $\begin{array}{l}0,94 \\
1,30\end{array}$ & $\begin{array}{l}0,37 \\
0,51\end{array}$ & $\begin{array}{c}7,9 \\
10,97\end{array}$ & $\begin{array}{l}19,3 \\
26,80\end{array}$ & $\begin{array}{l}26,6 \\
36,33\end{array}$ & $\begin{array}{l}0,] \\
0,15\end{array}$ & $\begin{array}{l}72,0 \mathrm{mg} / 1 * \\
98,27 \%\end{array}$ \\
\hline
\end{tabular}

Analista: Instituto Adolfo Lutz, São Paulo.

Observação: ** Os elementos traços não foram analisados.

\begin{tabular}{lclllllllllllll}
\hline Iha Sol & $\mathrm{mg} / 1$ & 0,8 & 0,6 & 5,8 & 1,6 & 9,0 & 0,4 & $0,12 * * 2,0$ & 15,5 & 1,6 & 0 & $38,0 \mathrm{mg} / 1$ \\
:ira & 8 & 2,10 & 1,57 & 15,26 & 4,21 & 23,68 & 1,05 & 0,31 & 5,26 & 40,78 & 4,21 & - & 99,81
\end{tabular}

Analista: Cecilia M. Coelho (DNPM) Rio de Janeiro.

* Mária Szikszay. 


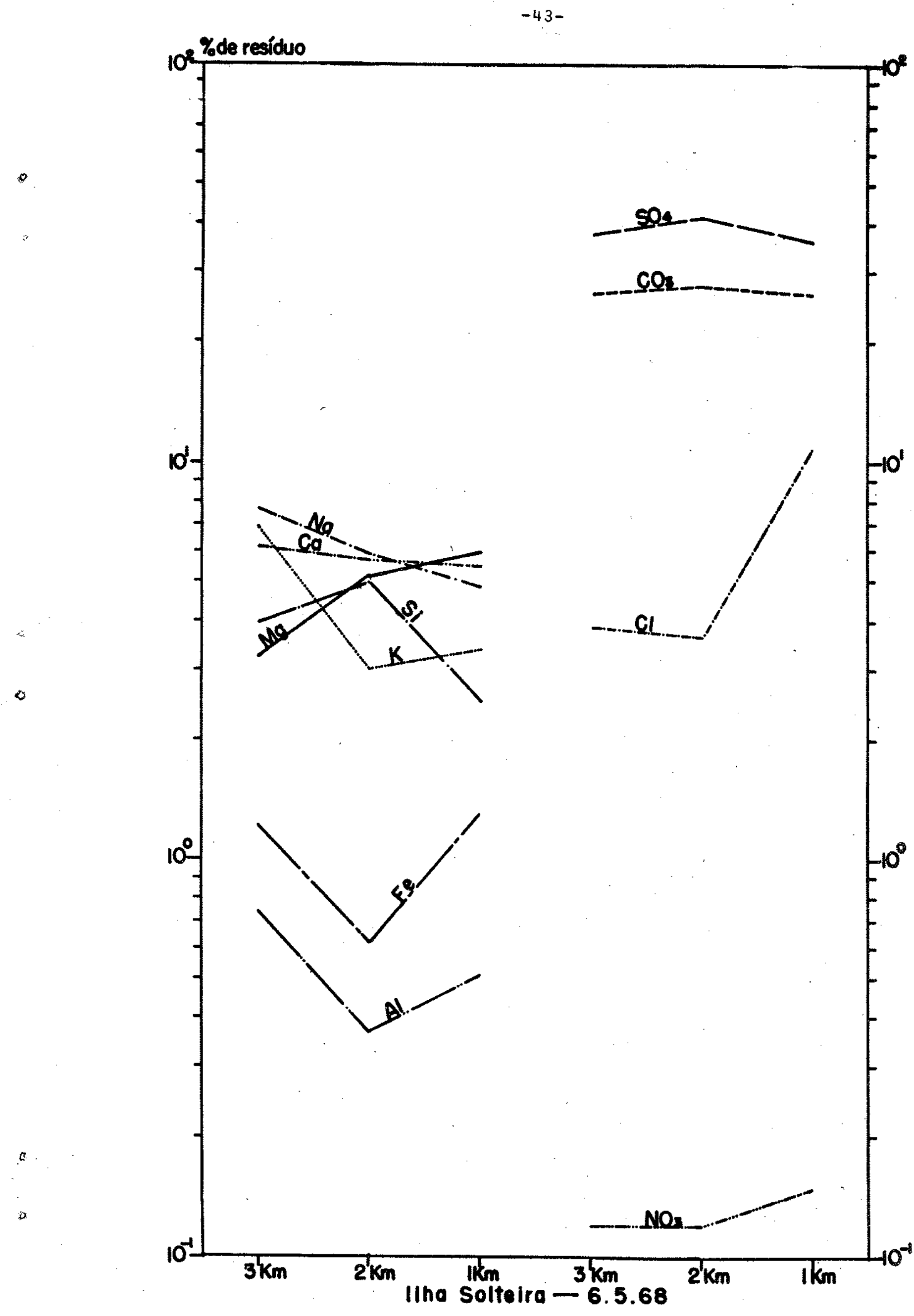

Figura 7 - Distribuição dos elementos maiores. (Rio Paraná - Ilha Solteira, mesmo dia.) 
Na Figura 7 observa-se a existência de variação nas concentrações dos componentes das águas, mesmo quan do os locais de coleta são pouco afastados, como no ca so em que as amostragens equidistam mais ou menos um quilómetro. Com relação ao $\mathrm{pH}$ e quantidade de material em solução, observa-se uma ligeira variação, porém me nos significativa.

Na Figura 7 observa-se um fato surpreendente, que é a concentração alta dos sulfatos no mês de maio de 1968. Como as coletas foram feitas após una forte chuva, êste fato fora do comum poderia ser decorrente das mesmas. Gorham (1958) estudou a concentração de sulfatos e cloretos das precipitações atmosféricas, afirmando que áreas industriais podem contribuir consi deràvelmente com os sulfatos para as nuvens. Uma outra possibilidade seria considerar as chuvas fortes como responsáveis pelo transporte de sulfatos, após lixiviá- los de terras tratadas com fertilizantes.

A terceira comparação é feita, com amostras coletadas no mesmo local, mas em anos e estações dife rentes, sendo uma no outono de 1968 e outra na primave ra de 1970 .

Os resultados dessa comparação estão no gráfico da Figura 8.

Na Figura 8 compara-se a mëdia dos valôres das anālises obtidas no dia 6 de maio de 1968 com a do dia 26 de outubro de 1970. Observa-se que a concentração do silício, cálcio, sódio, potássio, alumínio, magnésio, carbonato, sulfato e cloreto variaram com as estações e anos. 0 ferro manteve-se constante, independentemente do mês e ano ou estação. 


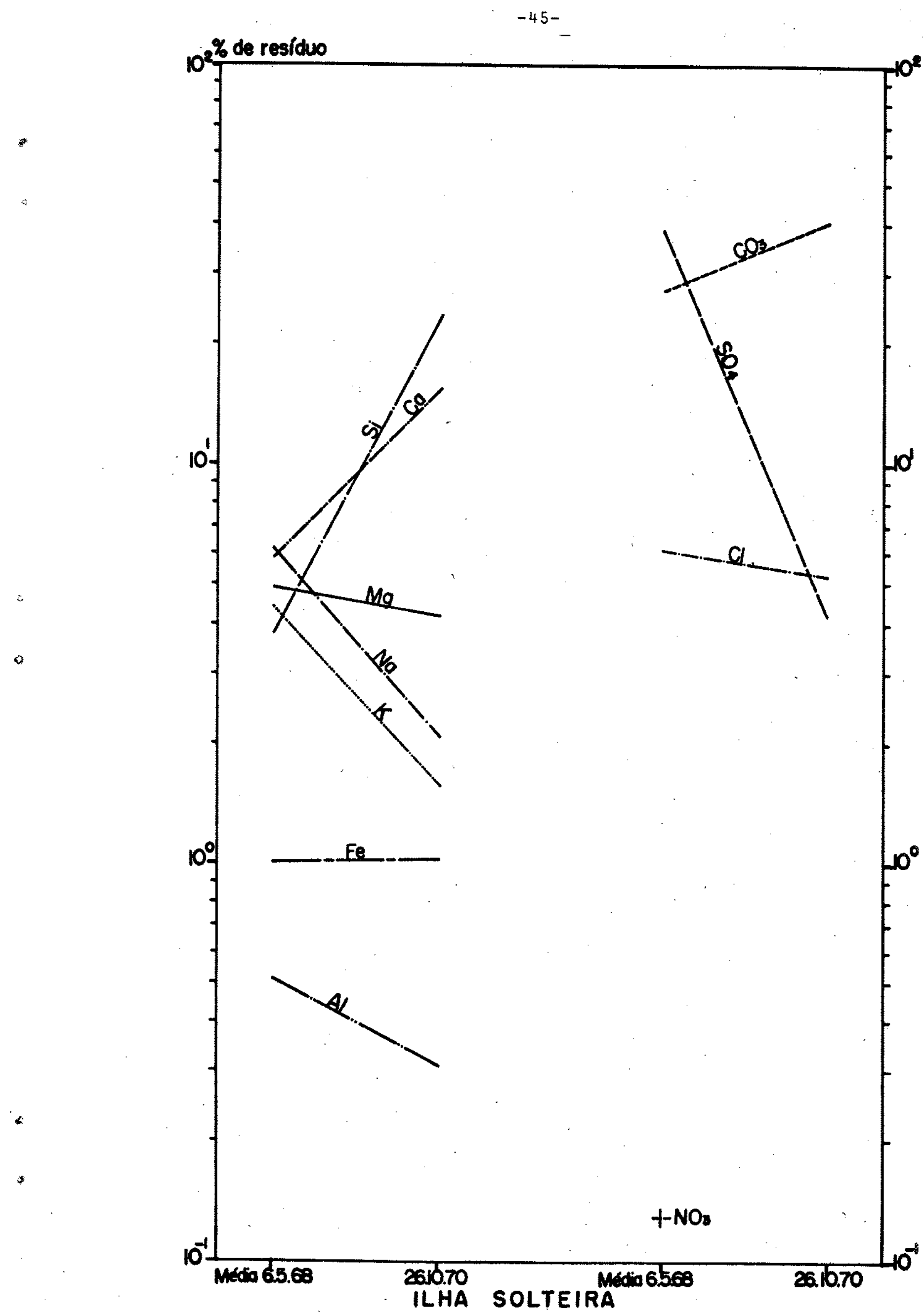

Figura 8 - Comparação dos elementos naiores (Rio Paranā - Ilha Solteira, épocas ciferentes). 
Uma quarta comparação feita, foi a variação dos elementos em águas coletadas no mesmo local, duran te um ano ou nas diversas estações.

Na Tabela 18 estão apresentados os resultados das análises das águas do rio Paraná coletadas em Jupiá durante o ano de 1964 e outra seis anos depois.

Na Tabela 19 apresentamos os resultados das anälises feitas por Kyle em 1878.

$\mathrm{Na} / \mathrm{K} \quad \mathrm{Ca} / \mathrm{Mg}$

$\begin{array}{lll}\text { Jupiá } 1964 \text { - janeiro } & 0,9 / 1,1=0,81 & 2,4 / 1,6=1,41 \\ \text { Jupiá } 1964 \text { - fevereiro } & 0,3 / 0,5=0,60 & 0,5 / 0,8=0,62 \\ \text { Jupiá } 1964 \text { - março } & 0,6 / 0,7=0,75 & 1,1 / 1,5=0,73 \\ \text { Jupiá } 1964 \text { - abril } & 0,6 / 0,8=0,75 & 1,1 / 1,4=0,78 \\ \text { Jupiá } 1964 \text { - maio } & 0,9 / 0,4=2,25 & 1,0 / 1,9=0,52 \\ \text { Jupiá } 1964 \text { - junho } & 1,3 / 0,9=1,44 . & 3,0 / 1,7=1,76 \\ \text { Jupiá } 1964 \text { - julho } & 0,6 / 0,7=0,85 & 1,8 / 2,7=0,66 \\ \text { Jupiá } 1964 \text { - agôsto } & 0,7 / 0,7=1,00 & 1,3 / 2,1=0,61 \\ \text { Jupiá } 1964 \text { - outubro } & 0,7 / 1,1=0,63 & 1,6 / 1,7=0,94 \\ & \mathrm{Na} / \mathrm{K}=1,02 & \mathrm{Ca} / \mathrm{Mg}=0,89\end{array}$

Tanto a razão $\mathrm{Na} / \mathrm{K}$ como $\mathrm{Ca} / \mathrm{Mg}$ não estão de acôrdo com a média padrão. Sòmente no mês de maio de 1964 que a razão Na/K se aproxima da média padrão. 
TABELA 18

Elementos meiores menores dlosados nas águas do rio Paraná, Jupiá ( $\operatorname{lng} / 1$ e percentagem do resíduo)

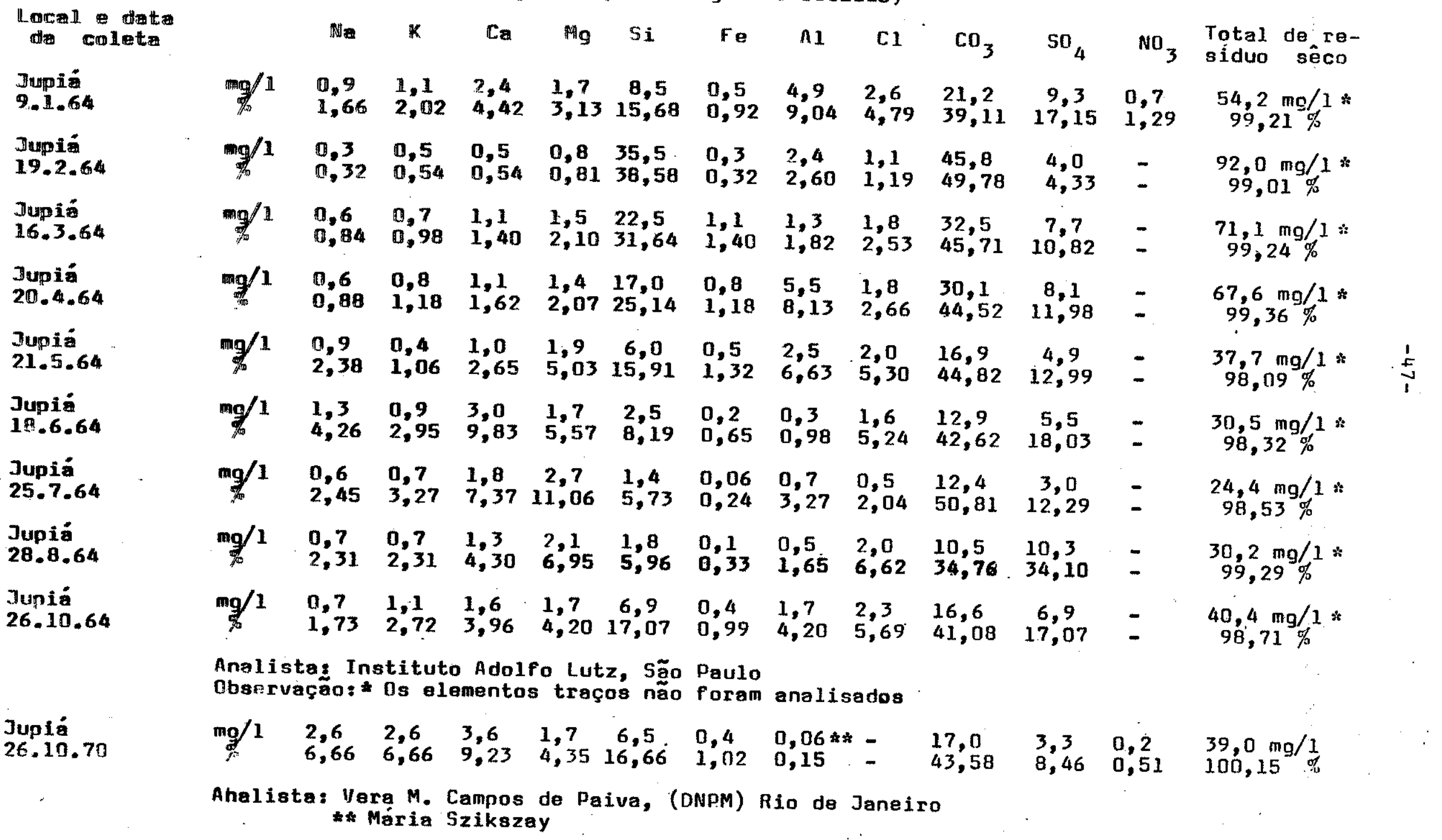


TABELA 19

Elementos maiores e menores dosados nas águas do rio Paraná ( $\mathrm{mg} / \mathrm{l}$ e percentagem)

$\begin{array}{lccccccccccccc}\begin{array}{l}\text { Local e data } \\ \text { da coleta }\end{array} & & \mathrm{Na} & \mathrm{K} & \mathrm{Ca} & \mathrm{Mg} & \mathrm{Si} & \mathrm{Fe} & \mathrm{Al} & \mathrm{Cl} & \mathrm{CO}_{3} & \mathrm{SO}_{4} & \mathrm{Total} \\ \begin{array}{l}5 \text { milhas antes } \\ \text { de La Plata }\end{array} & & 14,66 & 3,97 & 7,12 & 2,72 & 9,49 & 2,20 & 1,86 & 15,60 & 30,65 & 9,92 & 98,0 \mathrm{mg} / 1 & 1 \\ 1878 & \% & 14,96 & 4,06 & 7,27 & 2,77 & 9,58 & 2,24 & 1,89 & 15,91 & 31,27 & 10,12 & 100,07 & \%\end{array}$

Analista: Kyle 
Nas Figuras 9 e 10 apresenta-se a variação dos eiementos em águas coletadas no mesmo local, duran te um ano, segundo as diferentes estações.

Observando as Figuras 9 e 10 nota-se que o só dio, potássio, cáicio, magnésio, sulfato e cloreto têm concentração máxima no inverno e mínima no verão. 0 s $\underline{i}$ lício tem concentração mäxima no verão e minima no in verno, sendo responsável pela maior quantidade de resí duo sêco no verão. 0 alumínio e o ferro apresentam vạ riações com as estaçōes. O carbonato mostrou pouca va riação durante os meses de verão e primavera, diminuindo sua concentração com o fim do inverno.

A quantidade baixa de material em solução no inverno e alta no verão, contraria as referências encon tradas na literatura, nas quais a quantidade de mate rial em solução é maior no inverno. Essa anomalia é dé vido a alta percentagem de silício em solução.

0 valor do $\mathrm{pH}$ medido oscilou entre 7,0 e 7,8 .

Uma quinta comparação é feita com as concen trações de amostras coletadas no mesmo local, mesmo dia e mês, portanto mesma estação, mas em anos diferentes.

Na Tabela 18 observa-se a semelhança entre a quantidade de material em solução em 26 de outubro de 1964 e en 26 de outubro de 1970: respectivamente 40,4 $\mathrm{mg} / 1$ e $39,0 \mathrm{mg} / \mathrm{l}$.

No gráfico da Figura 11 estão apresentados os dados dessa comparação. 


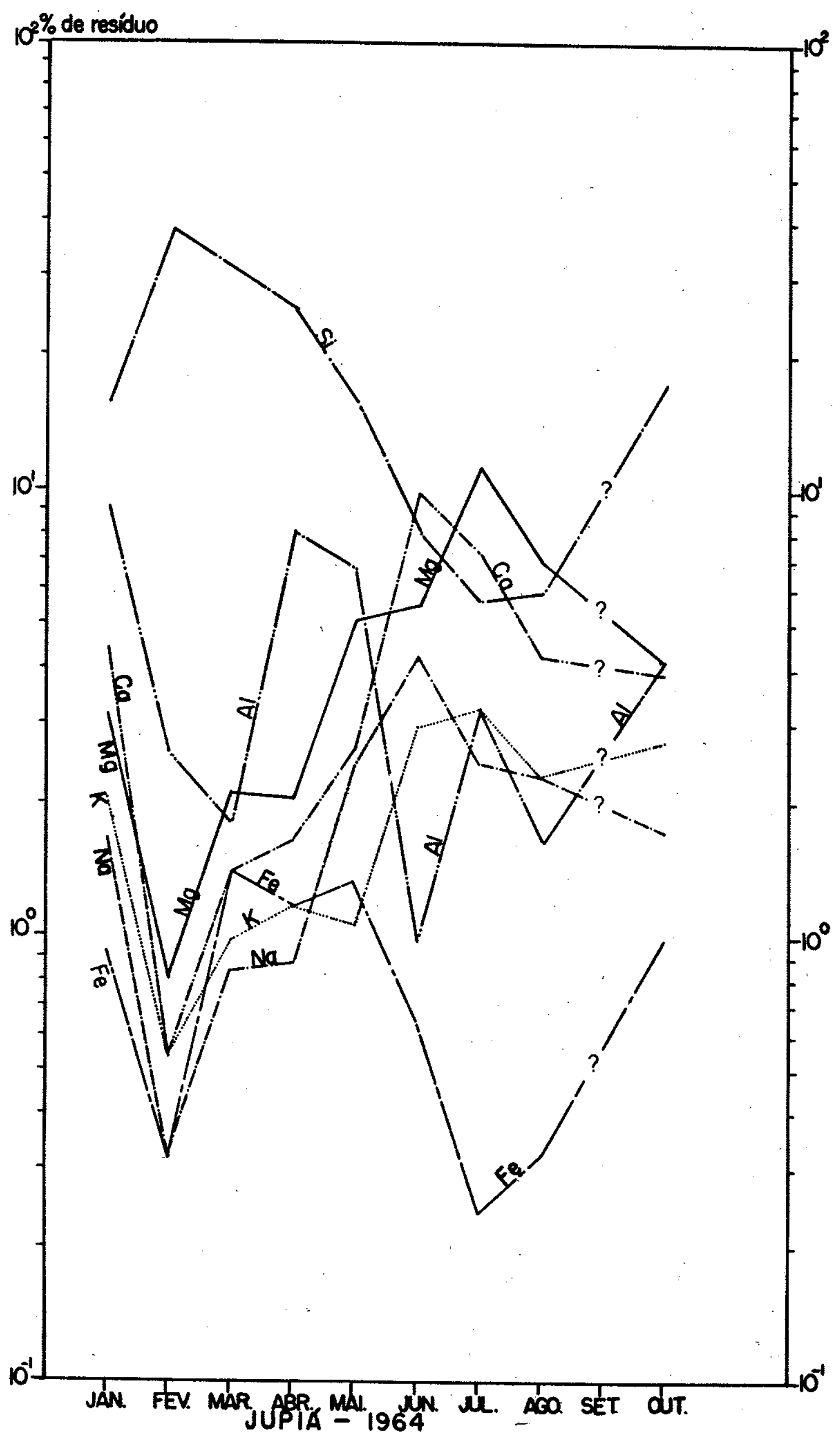

Figura 9 - Distribuição dos elementos maiores (cátions) duran te o ano de 1964 (Rio Paraná - Jupiá). 


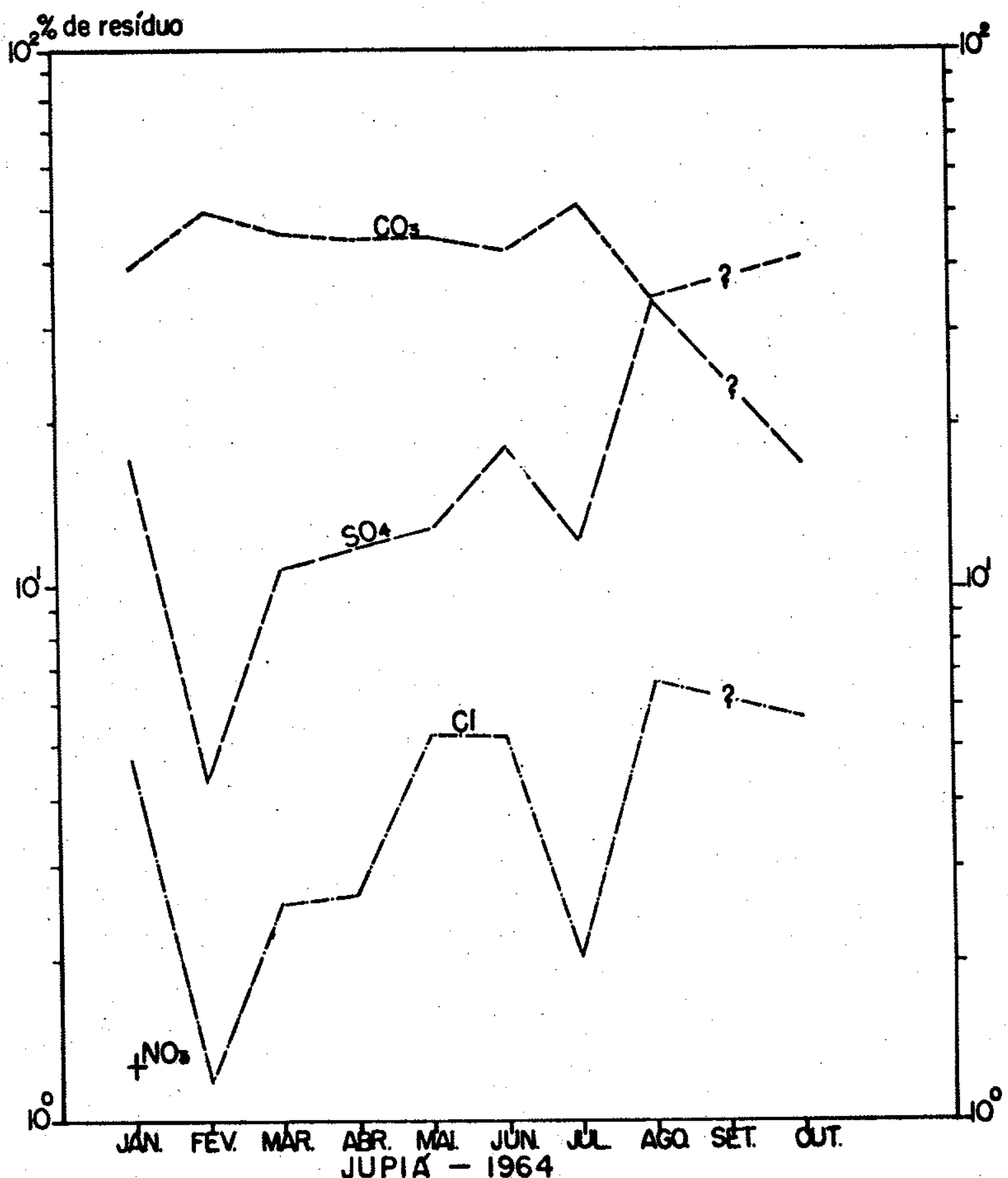

Figura 10 - Dístribuição dos elementos maiores (ânions) duran te $\circ$ ano de 1964 (Rio Paraná - Jupiá). 


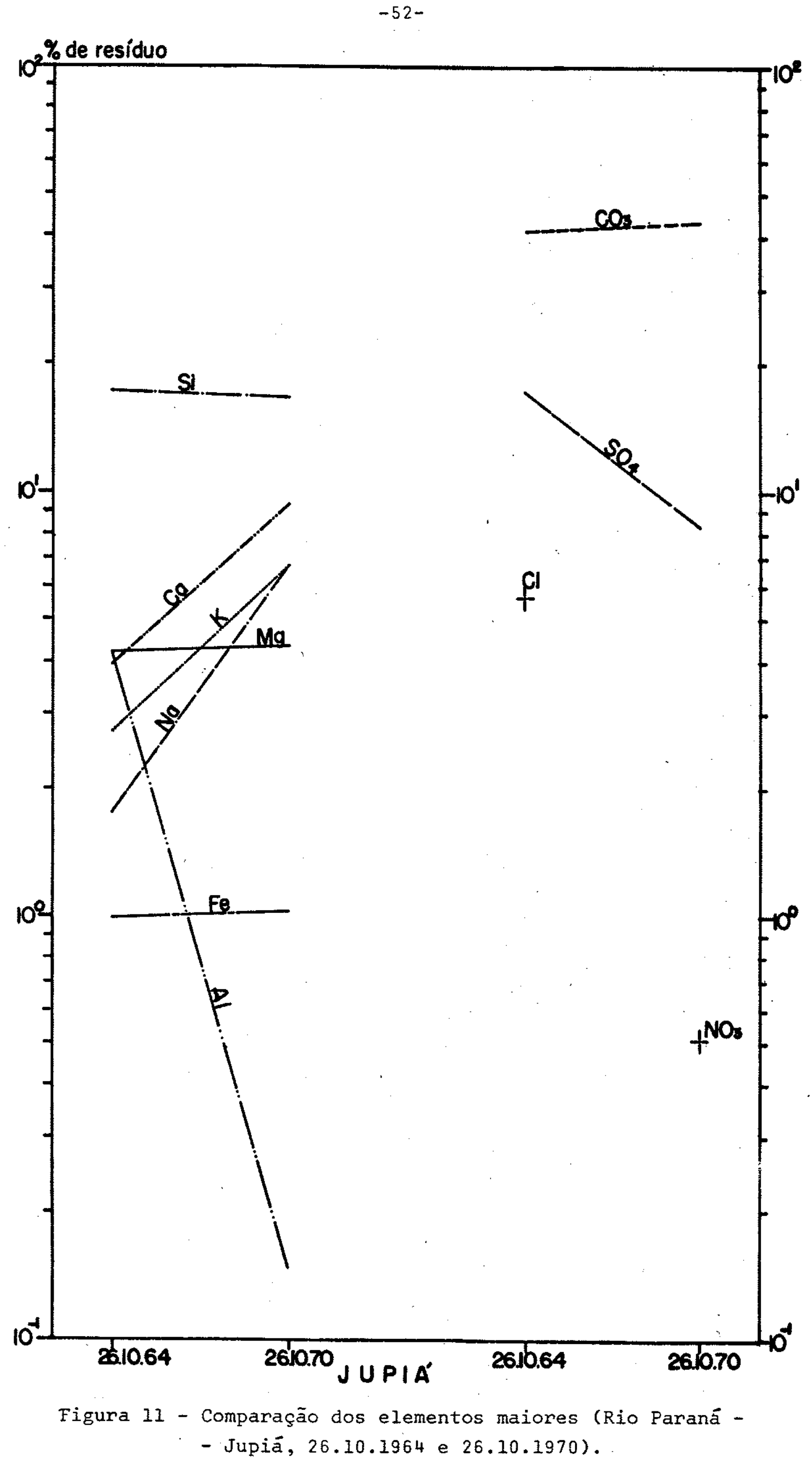


A Figura 11 mostra que no decorrer de seis anos houve variāção dos seguintes elementos: aluminio e sulfato diminuiram em concentração; cálcio, potássio,só dio e carbonato aumentaram; silício, magnésio e ferro permaneceram com concentrações mais ou menos iguais; cloreto e nitrato foram detectados apenas uma vez, clo reto na primeira determinação e nitrato na segunda.

$0 \mathrm{pH}$ sofreu ligeira variação de 7,3 em 26 de outubro de 1964 para 6,8 em 26 de outubro de 1970, cau sada talvez, por variação de chuvas ou variação da vege tação.

Compara-se a seguir, os resultados de coletas realizadas no dia 26 de outubro de 1970 no rio. Paraná, em dois locais diferentes - Ilha Solteira e Jupiá ( 56 $\mathrm{km}$ de distância).

$\mathrm{Na} F$ igura 12 o gräfico mostra as variações em concentração dos elementos maiores dos dois locais de coletá.

Na Figura 12 observa-se que as concentrações do silício, cálcio, alumínio diminuiram de um local pá ra outro, as do sódio, potássio, carbonato e sulfato aumentaram. O ferro e magnésio não apresentam varią ções. O cloreto e nitrato aparecem num único local, clo reto em Ilha Solteira e nitrato em Jupiá.

Conforme era esperado, a quantidade de mate rial em solução em Ilha Solteira é $38,0 \mathrm{mg} / 1$ e em Jupiá $39,0 \mathrm{mg} / 1$, mostrando que êsses valôres aumentam ao lon go do curso do rio.

$0 \mathrm{pH}$ medido nos dois lugares é 6,8 .

Os elementos traços estão apresentados na Tá 


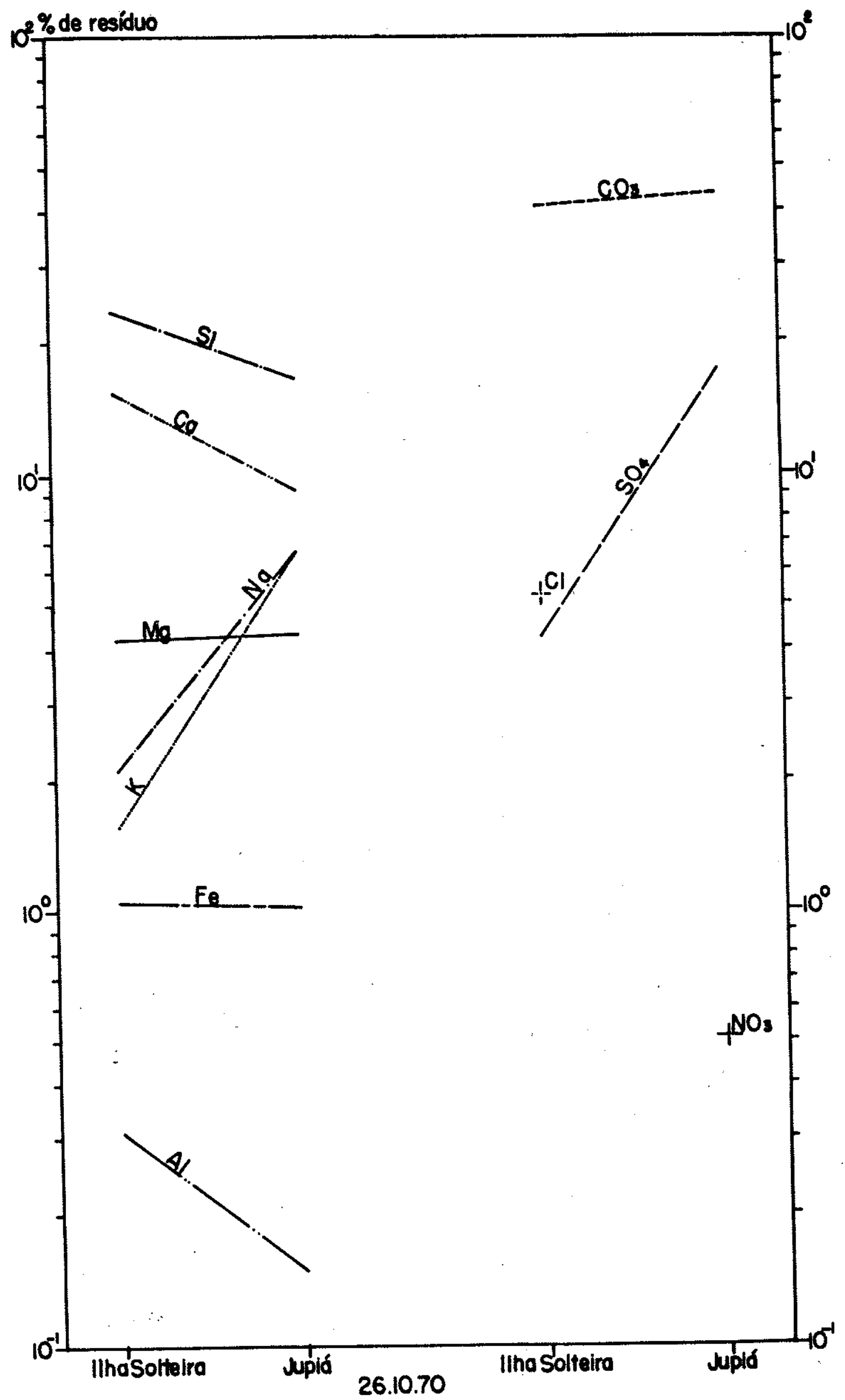

Figura 12 - Comparação dos elenentos naiores. (Rio Paraná -

- Ina solteira e Jupiá - 26 de outubro de 1970.) 
TABELA 20

Elementos traços dosados nas águas do rio Paraná (mg/l e percentagem do residuo)

\begin{tabular}{|c|c|c|c|c|c|c|c|}
\hline $\begin{array}{l}\text { Local e } \\
\text { data da } \\
\text { coleta }\end{array}$ & & B & V & $\mathrm{Ni}$ & Co & $\mathrm{Ti}$ & $\mathrm{Cu}$ \\
\hline $\begin{array}{l}\text { Ilha Sol } \\
\text { teira }\end{array}$ & $\mathrm{mg} / \mathrm{I}$ & 0,43 & 0,003 & 0,002 & 0,003 & 0,003 & 0,09 \\
\hline 26.10 .70 & $\%$ & 1,13 & 0,007 & 0,005 & 0,007 & 0,007 & 0,23 \\
\hline Jupiā & $\mathrm{mg} / \mathrm{l}$ & 0,82 & 0,03 & 0,001 & 0,06 & 0,12 & 0,10 \\
\hline 26.10 .70 & $\%$ & 2,10 & 0,07 & 0,002 & 0,15 & 0,30 & 0,25 \\
\hline
\end{tabular}

Os resultados da Tabela 20 estão representados no grä́rico da Figura 13.

Observarse na Figura 13, que houve um aumento na concentração de todos os elementos traços, com exce ção do níquel. Para o cobre, o aumento foi quase in significante. 


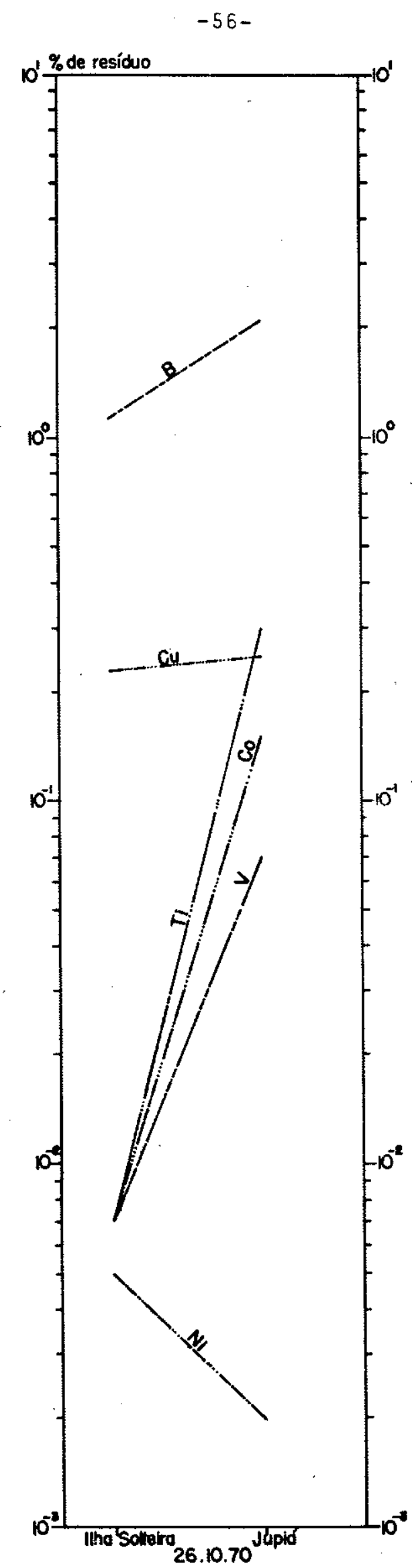

Figura 13 - Comparação dos elementos traços (Rio Paraná - Ilha Solteira e
Jupia - 26 de outubro de 1970). 
Compara-se a seguir a mëdia dos valôres dos rios Sucuriū, Tietê e Paraná (Ilha Solteira), com o vạ Ior obtido $56 \mathrm{~km}$ abaixo (Jupiá), trecho onde desembocam os rios Sucuriú e Tietê (Figura 2): A média das concentra ções do sódio, magnésio, silício, ferro, alumínio e sul fato $(2,6 ; 1,4 ; 7,6 ; 0,6 ; 0,05$ e $3,3 \mathrm{mg} / 1)$, obtidas nos rios Sucuriú, Tietê (desembocadura) e Paraná (Ilha Sol teira), são semelhantes aos valôres encontrados en Jupiá $(2,6 ; 1,7 ; 6,5 ; 0,4 ; 0,06$ e $3,3 \mathrm{mg} / 1$ respectivamente).

0 mesmo não se verifica para o cálcio,cloreto, carbonato e nitrato, cujos valôres médios (5,2; 1,6; $26,0$ e $0,4 \mathrm{mg} / \mathrm{l})$ são maiores que os valôres determinados em Jupiá ( 3,$6 ; 0,0 ; 17,0$ e $0,2 \mathrm{mg} / 1$ respectivamente).

0 potássio apresenta um comportamento diferen te, pois seu valor médio $(1,6 \mathrm{mg} / \mathrm{l})$ é menor que o valor encontrado em Jupiá $(2,6 \mathrm{mg} / 1)$.

Os elementos traços boro, vanádio, cobalto,ti tânio e cobre apresentam comportamento análogo ao potás sio, sendo suas concentrações em Jupiá $(0,82 ; 0,03 ; 0,06$; $0,12$ e $0,10 \mathrm{mg} / 1)$, maiores que as médias das três coletas acima $(0,20 ; 0,002 ; 0,021 ; 0,0017$ e $0,04 \mathrm{mg} / 1$ respectiva mente).

Em relação ao níquel, a média das concentra ções dos rios Sucuriú, Tietê e Paraná (Ilha Solteira) é maior $(0,04 \mathrm{mg} / 1)$ que o valor de Jupiá $(0,001 \mathrm{mg} / 1)$.

Estas comparações foram efetuadas, uma vez que tôdas as coletas foram realizadas na mesma estação ( prí mavera de 1970).

A relação do material em solução e em suspen são também foi examinada, e os resultados estão apresen tados na Tabela 21. 
TABELA 21

Razão solução/suspensão do material do rio Paraná.

\begin{tabular}{|c|c|c|c|c|}
\hline Local de coleta & Data & $\begin{array}{l}\text { Material } \\
\text { em solução } \\
\text { mg/l }\end{array}$ & $\begin{array}{c}\text { Material } \\
\text { em susp. } \\
\text { mg/l }\end{array}$ & $\frac{\text { Sol. }}{\text { Susp. }}$ \\
\hline $\begin{array}{l}+3 \mathrm{~km} \text { acima de } \\
\text { Illha Solteira }\end{array}$ & 6.5 .1968 & 76,14 & 60,4 & 1,2 \\
\hline $\begin{array}{l}+2 \mathrm{~km} \text { acima de } \\
\bar{I} \text { Iha Solteira }\end{array}$ & 6.5 .1968 & 82,9 & 98,0 & 0,8 \\
\hline $\begin{array}{l}+ \text { I } \mathrm{km} \text { acima de } \\
\text { Illha Solteira }\end{array}$ & 6.5 .1968 & 71,15 & 166,0 & 0,4 \\
\hline Jupiā & 9.1 .1964 & 54,2 & 21,6 & 2,5 \\
\hline Jupiā & 19.2 .1964 & 92,0 & 16,6 & 5,5 \\
\hline$\overline{\text { Jupiáa }}$ & 16.3 .1964 & 71,1 & 80,3 & 0,8 \\
\hline Jupiá & 20.4 .1964 & 67,6 & 44,0 & 1,5 \\
\hline Jupiā & 21.5 .1964 & 37,7 & 27,9 & 1,3 \\
\hline Jupiá & 18.6 .1964 & 30,5 & 12,0 & 2,5 \\
\hline Jupiá & 25.7 .1964 & 24,4 & 3,9 & 6,2 \\
\hline Jupiả & 28.8 .1964 & 30,2 & 13,1 & 2,3 \\
\hline$\overline{\text { Jupiāa }}$ & 26.10 .1964 & 40,4 & 19,8 & 2,0 \\
\hline
\end{tabular}

Os dados da Tabela 21 estão representados nos gráficos das Figuras 14 e 15 . 


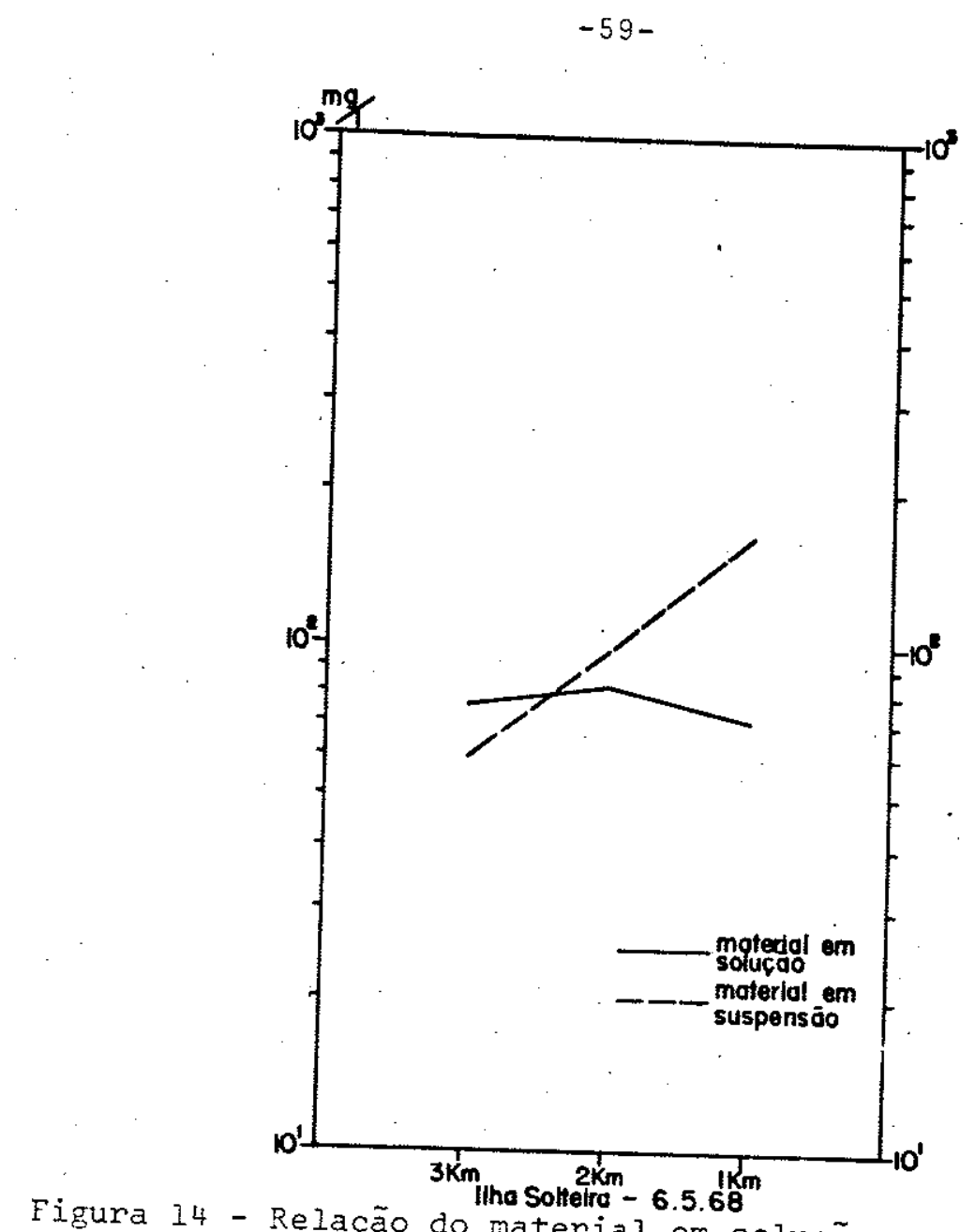

Figura 14 - Relação do material em solucão e en suspensão no mesmo dia (Rio Paraná - Ilha Solteira).

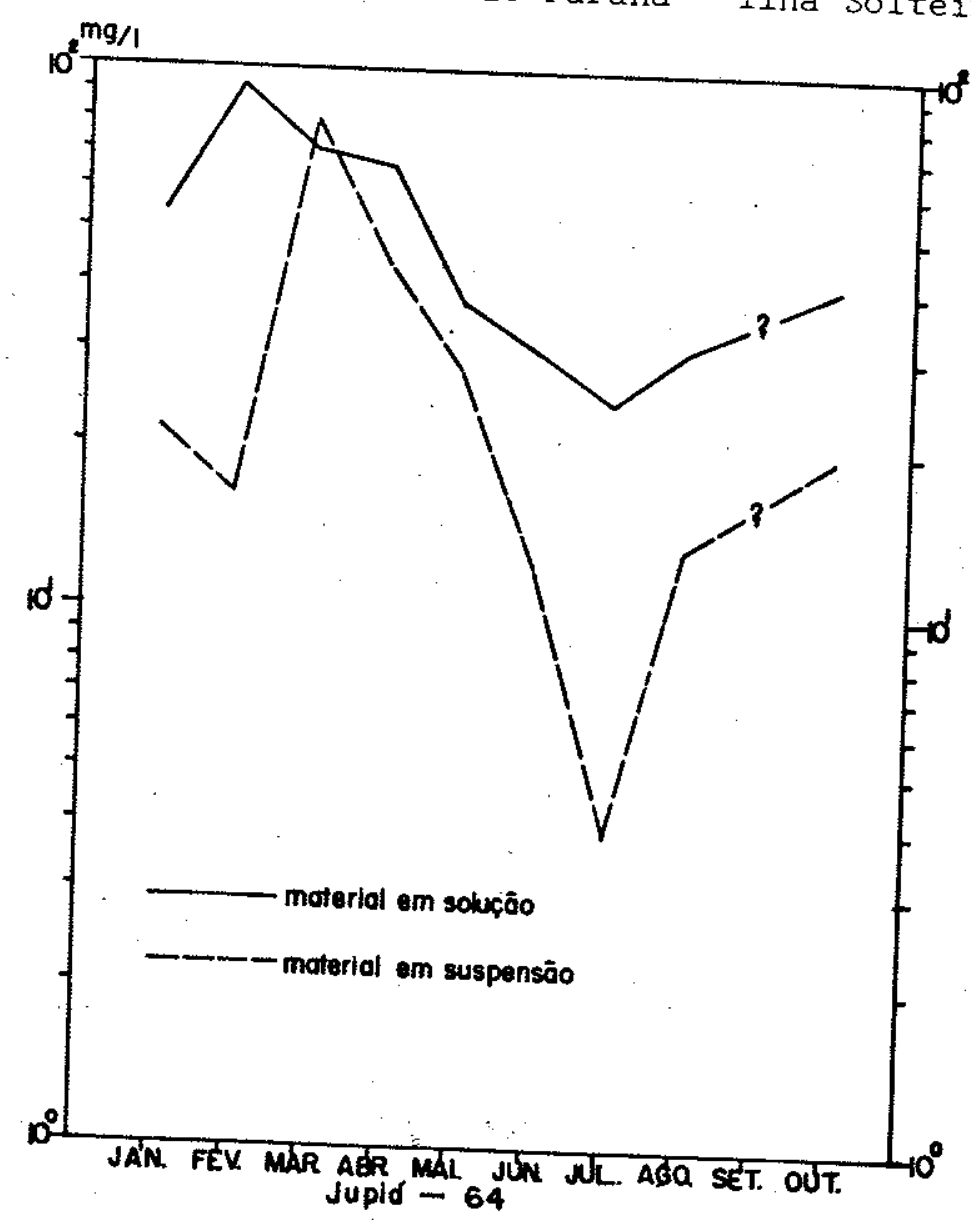

Figura $15^{\circ}$ - Relação do naterial em sollução e em suspensão durante um ano (Rio Paraná - Jupiá). 
A quantidade de material em solução e em sus pensão apresenta resultado bastante curioso. Como é có nhecido na literatura, o material em suspensão nas águas dos rios é quase sempre predominante sôbre o material em solução. Entretanto, nossos dados aparentam exata mente o contrário, com exceção de três casos, se bem que tôdas as amostras analisadas fossem coletadas na su perfície da água do rio. Certamente êste fato é o res ponsável por êste resultado aparentemente discrepante, pois é fato notório que o rio transporta em profundida de seu conteúdo em suspensão.

4. Rio Pelotas-Uruguai - Foi feita uma cole ta das águas do rio Pelotas no verão, no trecho próximo a ponte de divisa entre os Estados do Rio Grande do Sul e Santa Catarina, na BR-Il6 (Figura 2). Para fins com parativos, foram utilizados dados do rio Uruguai (conti nuação do rio Pelotas) feitos por Kyle em 1897 na localidade de Salto, e outro por Schoeller em 1877 na loca lidade de Frei Bento.

As rochas da área de drenagem do rio Pelotas-Uruguai são predominantemente basaltos.

Os resultados destas análises estão apresen tados nas Tabelas 22,23 e 24 . 
TABELA 22

Flementos maiores e menores dosados nas ánuas do rio Pelotas

$$
\text { ( } \mathrm{mg} / 1 \text { e percentagem do resíduo) }
$$

\begin{tabular}{|c|c|c|c|c|c|c|c|c|c|c|c|c|c|}
\hline $\begin{array}{l}\text { Local e data } \\
\text { da coleta }\end{array}$ & & $\mathrm{Na}$ & $k$ & $\mathrm{Ca}$ & $\mathrm{mg}$ & $5 i$ & $\mathrm{Fe}$ & $A_{1}$ & $\mathrm{C}_{1}$ & $\mathrm{CO}_{3}$ & $\mathrm{SO}_{4}$ & $\mathrm{NO}_{3}$ & $\begin{array}{l}\text { Total do re } \\
\text { síduo sêco }\end{array}$ \\
\hline Ponte RG/SC & $\mathrm{mg} / 1$ & 0,1 & 0,1 & 2,9 & 2,3 & 3,5 & 0,2 & 1,1 & 1,7 & 16,4 & 1,0 & 0,8 & $31,2 \mathrm{mg} / 1$ \\
\hline $\begin{array}{l}\text { BR } 116 \\
19.1 .1970\end{array}$ & $\%$ & 0,32 & 0,32 & 9,29 & 7,37 & 11,21 & 0,64 & 3,52 & 5,44 & 52,56 & 3,20 & 2,56 & $99,59 \%$ \\
\hline
\end{tabular}

TABELA 23

Flementos maiores e menores dosados nas áquas do rio Uruguai ( $\mathrm{mg} / \mathrm{l}$ e percentagem)

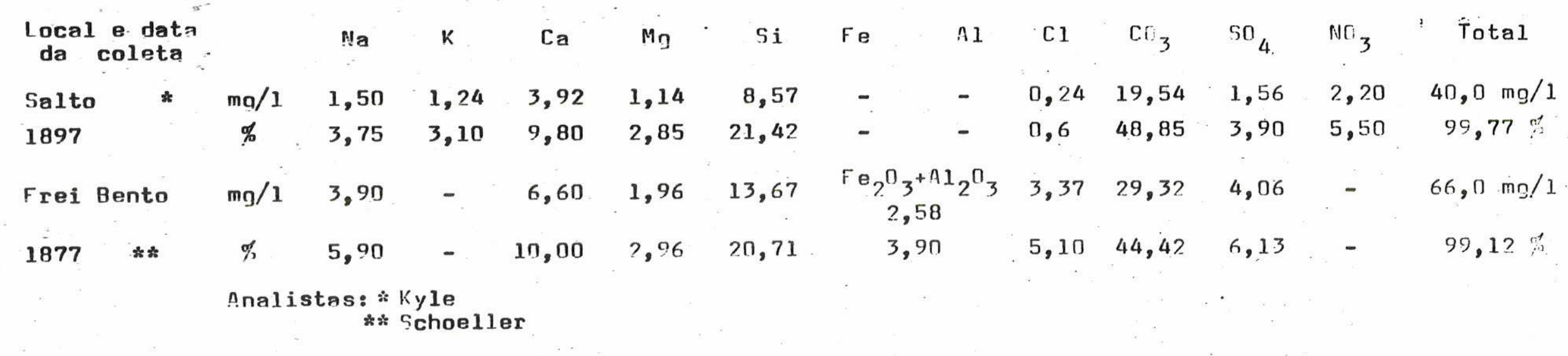


Elementos traços dosados nas águas do rio Pelotas ( $\mathrm{mg} / \mathrm{l}$ e percentagem do residuo).

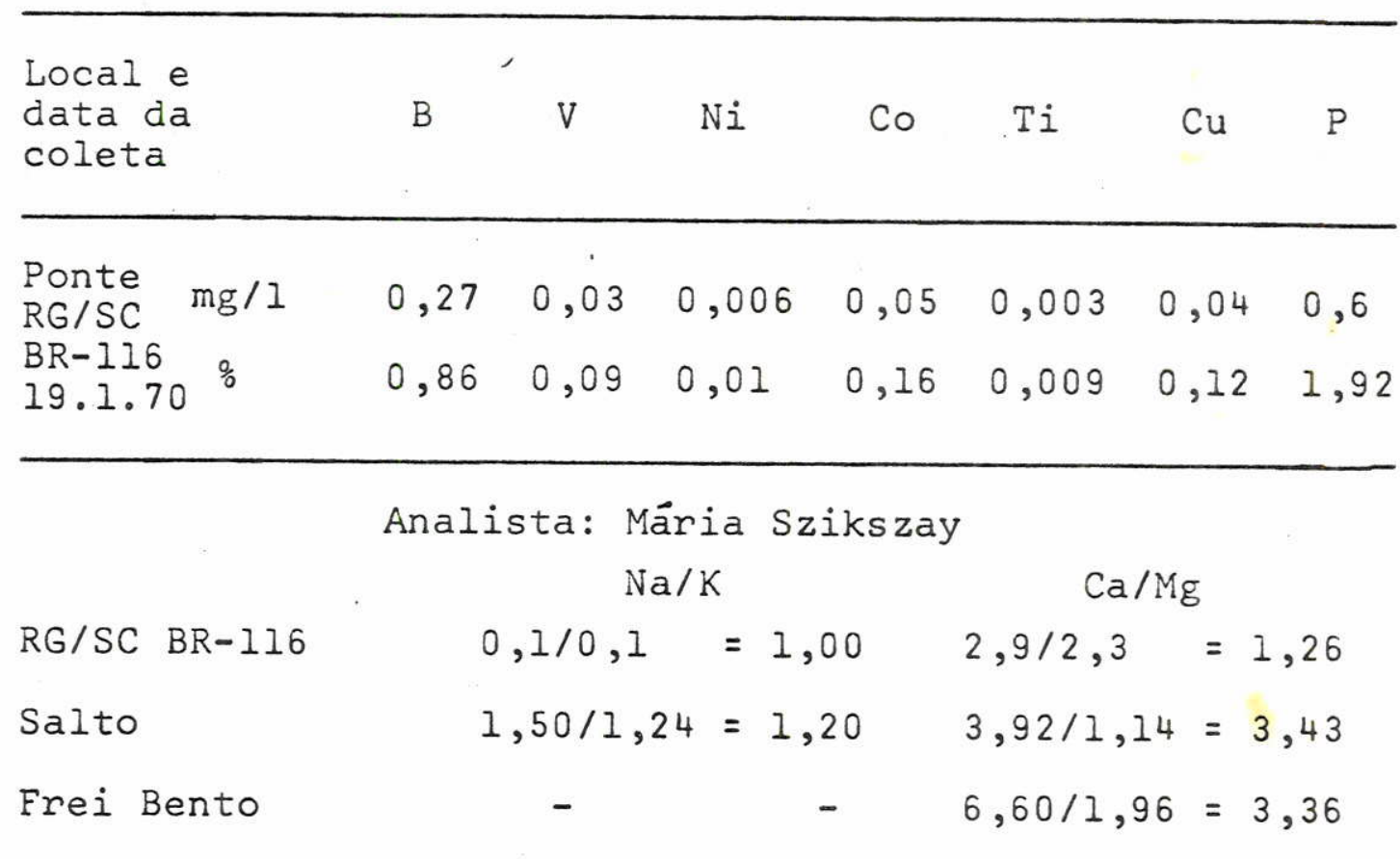

Tanto a razão Na/K como Ca/Mg não correspondem a média padrão.

Observa-se um elevado teor de concentração de boro e pela primeira vez, neste estudo, detectou-se fós foro.

O fósforo é detectável pelo método espectrográ fico, sòmente quando está presente em concentração acima de $1 \%$ nas amostras. Portanto, supõe-se que em outros rios, mesmo quando presente, deve apresentar-se em con centrações inferiores a $1 \%$.

Para observação global, apresentamos as Tabe las 25 e 26 onde se acham computados todos os resultados das análises dos elementos maiores, menores e elementos traços dos rios estudados, com os dados expressos em mg/ litro e em percentagem do resíduo. 
$-63-$
$-63-$

lementos maiores, menores a elementos tracos de todos os rios estudados
(Dados em mo/Litro de residuo)

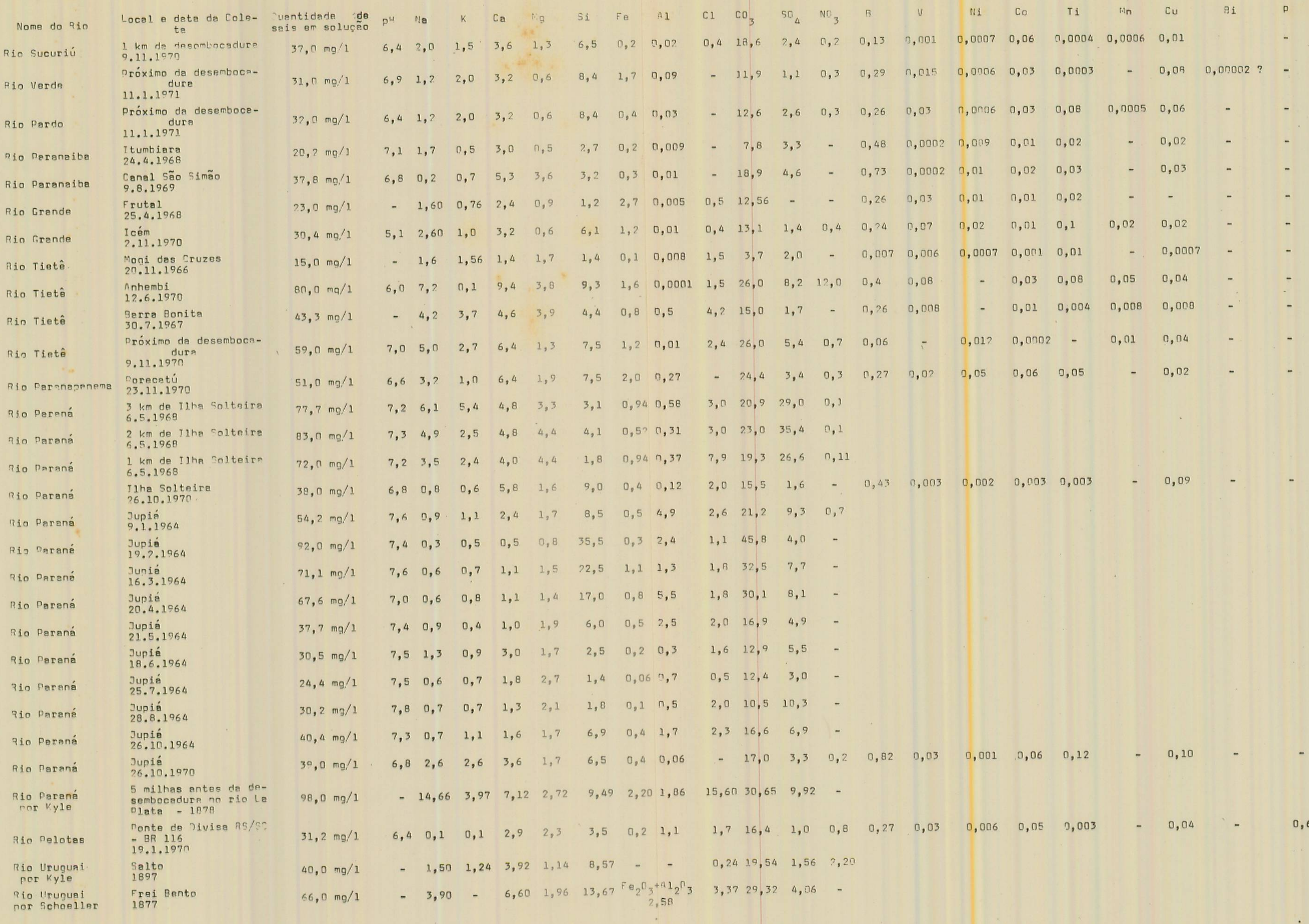


Nome do Pin Local a data ta cale-

ric sucurition

s.ip verde

$1 \mathrm{~km}$ de desambncadura
9.11 .1970

Próximo de desemboca-

Rio Dardo

Pis o

Dróximo da

11.1.1971
Itumbiara
24.4 .1968

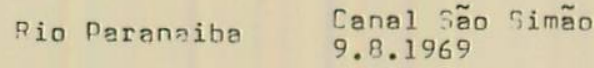

$\begin{array}{ll}\text { Rio Grande } & \text { Frutal } \\ 25.4 .1968\end{array}$

Ric Grande Icám 2.11 .1970

Rin Tietê 20.11 .1966 Cruzes

$\begin{array}{ll}\text { Rio Tietê } & \text { nnherbi } \\ & 12.6 .1970\end{array}$

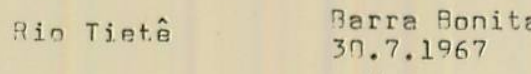

Rin Tietê Fríximo da de
9.11 .1970

Rio Daranananama Porecetú

Pin Doraná $\begin{array}{ll}3 \mathrm{~km} \text { de } & \text { Ilthe colteire } \\ 6.5 .1968\end{array}$

$2 \mathrm{~km}$ de t1ra soltaire
6.5 .1968

$1 \mathrm{~km}$ de IThe Snlteira
6.5 .1968

I? he solteire
?h. 1 n. 1970

Zun:é

Tupiá
19. .1964

Juniá

Jupié
20.4 .1964

Jupié
J1.5. 1964

Jupiá
18.5 .1964

Jupiá
25.7 .1964

7upié
78.8 .1964

Jupiá
26.10 .1954

Rín Perzáá Tupiá 25.10 .1970

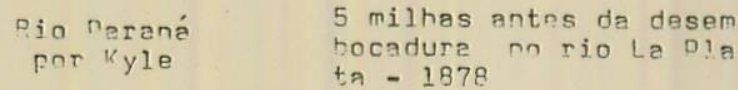

Panto de hivise 75/5C

$\begin{array}{ll}\text { Pio Delotas } & \text { Pante de } \\ \text { Rp } 115 \\ & 19.11970\end{array}$

$\begin{array}{ll}\text { nin "rupuai } & \text { Salto } \\ \text { por Kyle } & 1897\end{array}$

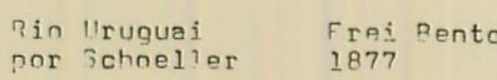

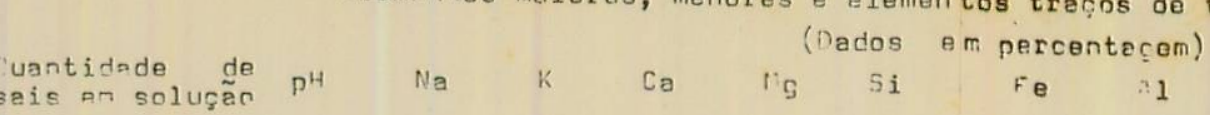

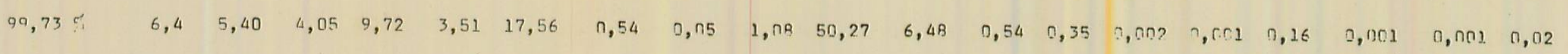

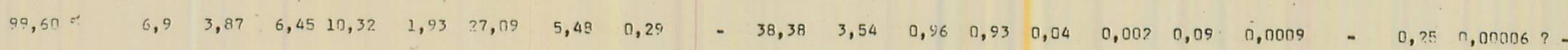

$\begin{array}{cllllllllllllllllllll}9,48 & 6,4 & 3,75 & 6,25 & 10,00 & 1,87 & 26,25 & 1,25 & 0,09 & -39,37 & 8,12 & 0,93 & 0,81 & 0,09 & 0,002 & 0,09 & 0,25 & 0,001 & 0,18\end{array}$

$\begin{array}{lllllllllllllllllllll}100,16 & 7,1 & 8,41 & 2,47 & 14,85 & 2,47 & 13,36 & 0,99 & 0,04 & -38,61 & 16,33 & - & 2,37 & 0,009 & 0,04 & 0,04 & 0,09\end{array}$

$\begin{array}{lllllllllllllllllllllllll}99,42 & 6,8 & 0,52 & 1,85 & 14,02 & 9,46 & 8,46 & 0,79 & 0,02 & -50,00 & 12,16 & - & 1,93 & 0,008 & 0,0 ? & 0,05 & 0,07\end{array}$

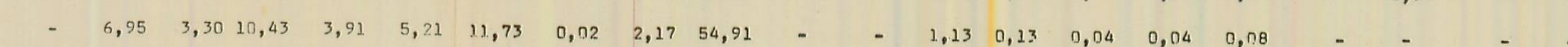

$1.00,20 \% \quad \begin{array}{llllllllllllllllllllll}5,1 & 8,55 & 3,28 & 10,52 & 1,97 & 20,06 & 3,94 & 0,03 & 1,31 & 43,09 & 4,60 & 1,31 & 0,78 & 0,33 & 0,06 & 0,03 & 0,32 & 0,06 & 0,06 & -\end{array}$

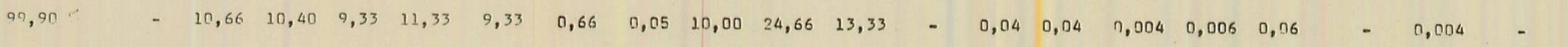

$\begin{array}{llllllllllllllllllllllll}99,50 & 6 & 6,0 & 9,00 & 0,12 & 11,75 & 4,75 & 11,62 & 2,0 & 0,00 & 0,87 & 32,50 & 10,25 & 15,00 & 0,50 & 0,10 & - & 0,03 & 0,10 & 0,06 & 0,05 & -\end{array}$

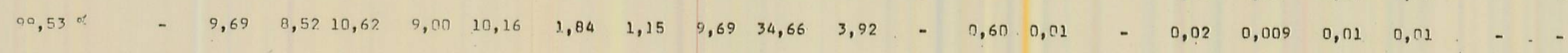

$\begin{array}{lllllllllllllllllllllllllll}99,65 \% & 7,0 & 8,47 & 4,57 & 10,84 & 2,20 & 12,71 & 2,03 & 0,01 & 4,06 & 44,06 & 9,15 & 1,18 & 0,10 & - & 0,20 & 0,0003 & - & 0,01 & 0,06 & - & -\end{array}$

$\begin{array}{lllllllllllllllllllllllll}99,58 & 6,6 & 6,27 & 1,96 & 12,34 & 3,72 & 14,70 & 3,92 & 0,57 & - & 47,84 & 6,66 & 0,58 & 0,52 & 0,03 & 0,09 & 0,11 & 0,09 & - & 0,03 & - & -\end{array}$

$\begin{array}{lllllllllllll}98,28 & 7,2 & 7,86 & 6,95 & 6,18 & 3,25 & 3,99 & 1,21 & 0,74 & 3,86 & 26,75 & 37,37 & 0,12\end{array}$

$\begin{array}{llllllllllllll}99,88 & 7,3 & 5,90 & 3,01 & 5,78 & 5,18 & 4,93 & 0,62 & 0,37 & 3,61 & 27,71 & 42,65 & 0,12\end{array}$

$\begin{array}{llllllllllllllll}98,27 & 7,2 & 4,86 & 3,33 & 5,55 & 5,97 & 2,57 & 1,30 & 0,51 & 17,97 & 26,80 & 36,33 & 0,15\end{array}$

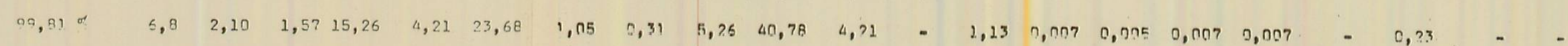

$\begin{array}{llllllllllllll}00,21 & 7,6 & 1,66 & 2,02 & 4,42 & 3,13 & 15,68 & 0,92 & 9,011 & 4,79 & 39,11 & 17,15 & 1,29\end{array}$

$\begin{array}{lllllllllllllllllll}9,01 & 7,4 & 7,4 & 0,32 & 0,54 & 0,54 & 0,81 & 38,58 & 0,32 & 2,60 & 1,19 & 49,78 & 4,33 & -\end{array}$

$99,24 \quad 7,6 \quad 0,84 \quad 0,93 \quad 1,40 \quad 2,10 \quad 31,64 \quad 1,40 \quad 1,82 \quad 2,53 \quad 45,71 \quad 17,82 \quad-$

$\begin{array}{lllllllllllllll}00,36 & 7,0 & 0,88 & 1,18 & 1,62 & 2,07 & 25,14 & 1,18 & 0,13 & 2,66 & 44,52 & 11,98 & -\end{array}$

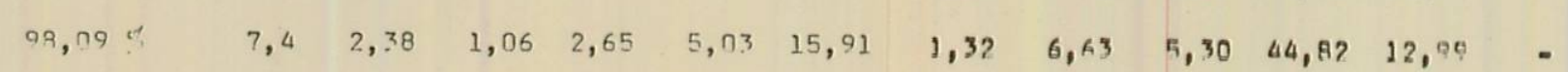

$\begin{array}{llllllllllllll}98,30 & 7,5 & 4,26 & 2,95 & 9,83 & 5,57 & 8,19 & 9,65 & 0,98 & 4,24 & 49,62 & 18,03\end{array}$.

$\begin{array}{llllllllllllll}09,53 & 7,5 & 2,45 & 3,27 & 7,37 & 11,06 & 5,73 & 0,94 & 3,27 & 2,04 & 50,81 & 12,70\end{array}$

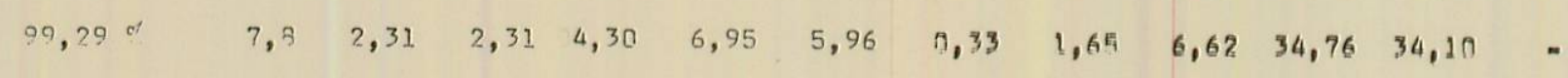

$\begin{array}{lllllllllllllll}99,71 & 7,3 & 1,73 & 2,72 & 3,96 & 4,20 & 17,07 & 0,09 & 4,20 & 5,69 & 41,08 & 17,07\end{array}$.

$\begin{array}{lllllllllllllllllllllllll}100,15 & 6,8 & 6,66 & 6,66 & 9,23 & 4,35 & 16,66 & 1,02 & 0,15 & -43,58 & 8,46 & 0,51 & 2,10 & 0,07 & 0,002 & 0,15 & 0,30 & - & 0,25 & - & -\end{array}$

$100,07 \quad-\quad 14,96 \quad 4,06 \quad 7,27 \quad 2,77 \quad 9,58 \quad 9,24 \quad 1,89 \quad 18,91 \quad 31,27 \quad 19,12 \quad$.

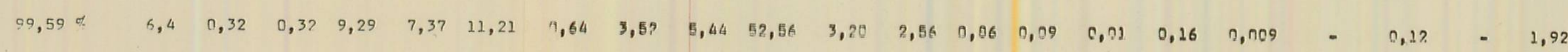

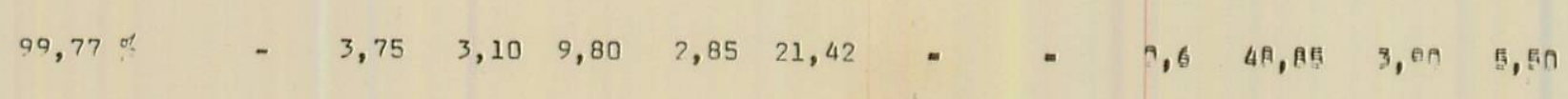

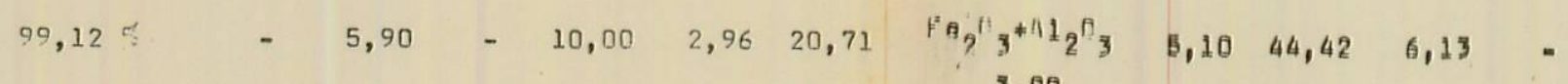


b - Comparação da Composição Química dos rios das margens direita e esquerda do rio Paraná.

Na Figura 16 apresentamos a média dos elemen tos dos rios da margem direita do rio Paraná (rios Sucu riū, Verde e Pardo) e os da margem esquerda (rios Para naíba, Grande, Tietê e Paranapanema). A amostragem da margem direita não tem a mesma frequência da executada na margem esquerda.

Como se observa na Figura 16, a quantidade de elementos em solução quase sempre predomina entre os afluentes da margem esquerda. Há exceção para a média do potássio, silício, cobalto e cobre. Os rios da mar gem direita drenam regiões de rochas predominantemente basälticas.

De acôrdo com Ruegg (1969), os basaltos da bacia do Paraná, têm uma concentração elevada em potás sio e cobre. Êste fato talvez explique, em parte, a con centração maior do potássio e cobre na margem direita.

Sinelli (1970) estudou a composição química das águas subterrâneas e verificou que as maiores con centrações de silica são encontradas em poços perfura dos em basaltos.

Davis (1964) afirma que a mineralogia é um dos fatores mais importantes no contrôle da concentra ção de silício na água. Concentrações menos elevadas são encontradas em regiões de rochas sedimentares, pois nestes últimos tipos litológicos, o silício se encontra em edifícios cristalinos mais estáveis e de dificil al teração. O referido autor encontrou valôres de 5 ppm 


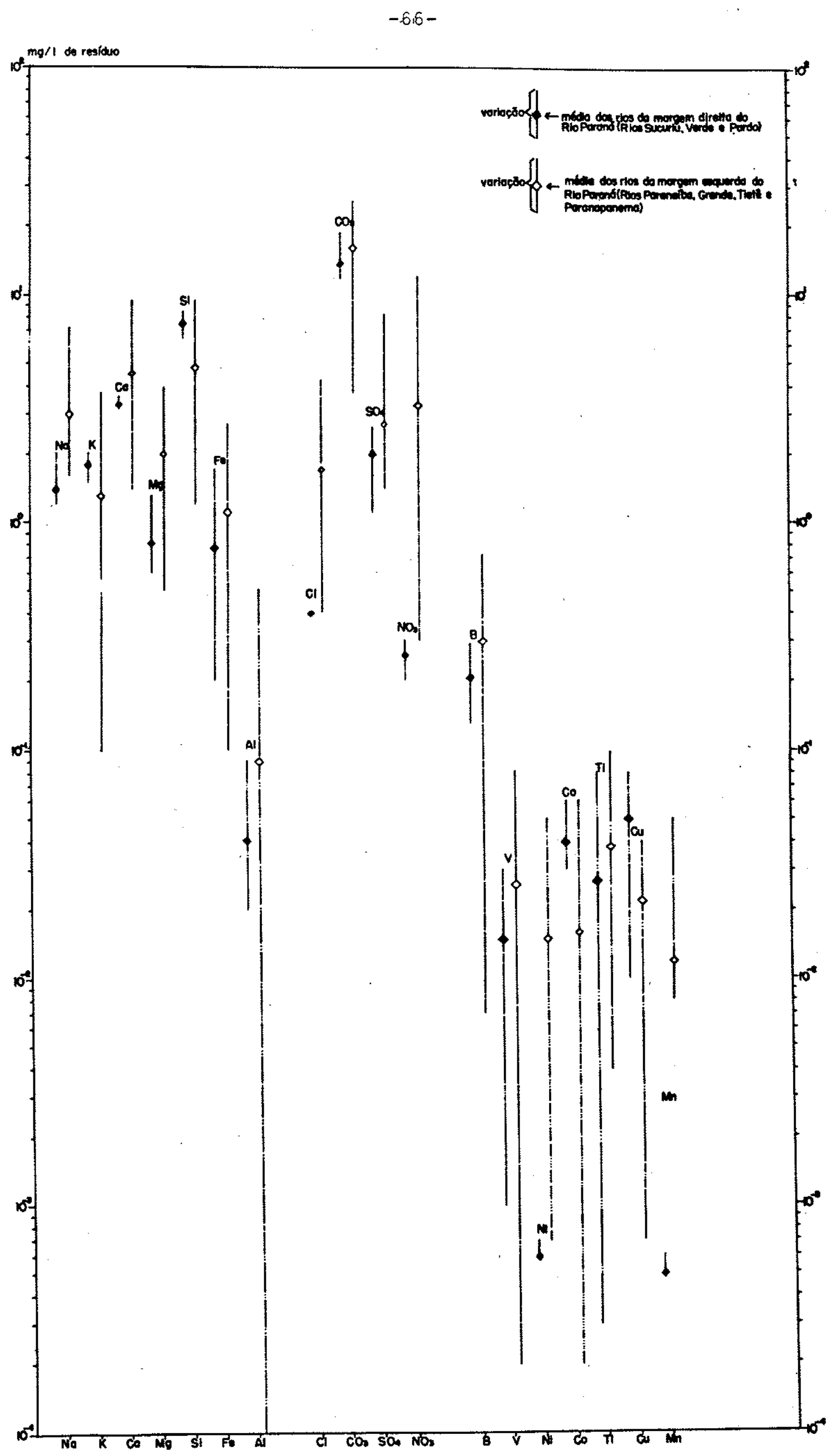

Figura ló - Comparação da composição química média dos rios da margem direita e esquerca do rio Paraná. 
de $\mathrm{SiO}_{2}$ em águas que drenavam basalto intemperizado, e $50 \mathrm{ppm}$ de $\mathrm{SiO}_{2}$ em locais de basaltos sem intemperismo, na mesma área.

Como se observa os cloretos estão em concen trações mais elevadas na margem esquerda, $\circ$ que pode ser explicado talvez pela maior proximidade do mar.

Observando os valôres médios da relação $\mathrm{Na} / \mathrm{K}$, vemos que os rios da margem esquerda do Paraná apresen tam resultados que se aproximam muito da média padrão. Porém, quando observamos os valôres $\mathrm{Ca} / \mathrm{Mg}$, verificamos exatamente o contrário, isto é, os resultados das mé dias encontradas na margem direita é que mais se apro ximam da média padrão.

Razão média Na/K nas águas da margem di reita do rio Paraná

$$
\begin{array}{ll}
\text { Sucuriú } & \mathrm{Na} / \mathrm{K}=1,33 \\
\text { Verde } & \mathrm{Na} / \mathrm{K}=0,6 \\
\text { Pardo } & \mathrm{Na} / \mathrm{K}=0,6
\end{array}
$$

Média $\mathrm{Na} / \mathrm{K}=0,84$

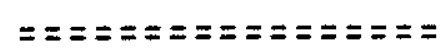

Razão média $\mathrm{Na/K}$ nas águas da margen esquerda do rio Paraná

$\begin{array}{ll}\text { Paranaiba } & \mathrm{Na} / \mathrm{K}=1,84 \\ \text { Grance } & \mathrm{Na} / \mathrm{K}=2,35 \\ \text { Tietê } & \mathrm{Na} / \mathrm{K}=2,80 \\ \text { Paranapanema } & \mathrm{Na} / \mathrm{K}=3,20\end{array}$

Média Na/K $=2,54$ 

Razão média Ca/Mg nas
ăguas da margem direi
ta do rio Paraná

Sucuriú Ca/Mg $=2,76$

Verde $\quad \mathrm{Ca} / \mathrm{Mg}=5,33$

Pardo

$$
\mathrm{Ca} / \mathrm{Mg}=5,33
$$

Média $\mathrm{Ca} / \mathrm{Mg}=4,47$

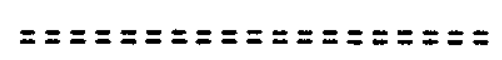

Razão média Ca/Mg nas águas da margem esquerda do rio Paraná

\author{
Paranaíba $\quad \mathrm{Ca} / \mathrm{Mg}=3,73$ \\ Grande $\quad \mathrm{Ca} / \mathrm{Mg}=3,99$ \\ Tietê $\quad \mathrm{Ca} / \mathrm{Mg}=2,33$ \\ Paranapanema $\mathrm{Ca} / \mathrm{Mg}=3,36$
}

Média $\mathrm{Ca} / \mathrm{Mg}=3,37$

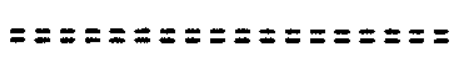

Na margem esquerda os rios recebem a infiuência de rochas do embasamento cristalino, enquanto na mar gen direita, as rochas predominantes são basaltos. Na margem direita existe mais potássio em solução do que na margem esquerda, onde existem mais sedimentos consti tuídos por argilo-minerais capazes de adsorverem o pó tássio.

o teor de magnésio em solução é maior na mar gem esquerda, devido a influência das rochas do embasá mento cristalino. Conforme Szikszay (1967), algumas ana lises de gnaisses das margens do rio Paraíba apresenta ram teores de nagnésio mais elevados do que cálcio.

A interpretação para o comportamento das rela ções $\mathrm{Na} / \mathrm{K}$ e $\mathrm{Ca} / \mathrm{Mg}$ de nossos rios é difícil de ser enten dida. Acreditamos que um dos fatores importantes seja, - solo, pois os rios da margem esquerda atravessam, alëm de zonas com solo laterítico, constituído predominantemen te por gibsita e óxidos e hidróxidos de ferro, zonas com 
solos constituidos por argilo-minerais capazes de adsor verem potássio e magnésio mais fàcilmente que sódio e cálcio. O outro fator importante é o fornecimento dês tes elementos pela litologia com concentrações altas em potássio e magnésio.

Comparando as médias das razões $\mathrm{Na} / \mathrm{K}$ e $\mathrm{Ca} / \mathrm{Mg}$. com as médias de outros continentes (Livingstone, 1963), observamos que nas águas dos rios de regiões tropicais e subtropicais a relação $\mathrm{Na} / \mathrm{K}$ e $\mathrm{Ca} / \mathrm{Mg}$ tende para valố res mais baixos, o que poderia significar maior quanti dade de potássio e magnésio em solução.

$$
\begin{aligned}
& \begin{array}{rrr}
\text { Europa Ásia Africa Austrá } & \text { Am. } & \text { Am. } \\
\text { lia } & \text { Norte Sul }
\end{array} \\
& \mathrm{Na} / \mathrm{K}=\frac{5,4}{1,7}=3,1 \quad-\quad \frac{2,9}{1,4}=2,0 \quad \frac{9,0}{1,4}=6,4 \stackrel{4}{2}=2,0
\end{aligned}
$$

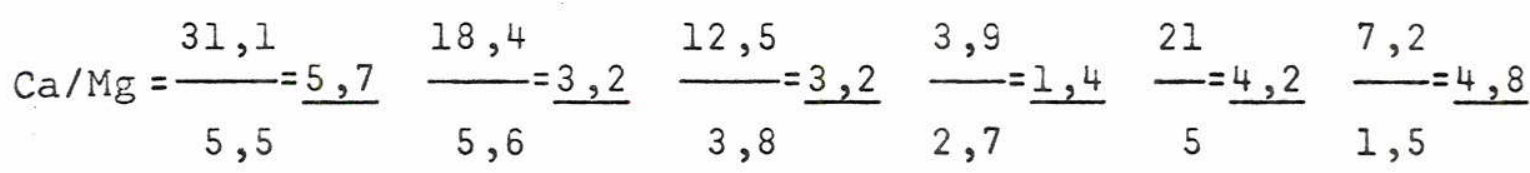

$$
\begin{aligned}
& \text { Comparando as médias de Livingstone (1963), }
\end{aligned}
$$


b) a média da razão $\mathrm{Ca} / \mathrm{Mg}=3,92$ aproxima-se das médias das razões da Africa $(3,2)$, Ásia $(3,2)$ e Amë ria do Norte $(4,2)$.

c - Relação entre concentração e värios fä tôres.

1. Relação da concentração dos elementos com variação sazonal.

A média de sais dissolvidos em águas de rios é $100-200$ ppm (Clarke, 1924). Nas regiões tropi cais e subtropicais essa quantidade é muito mais baixa. Em águas de rios de regiões tropicais, a salinidade é baixa, porque os rios drenam áreas de solos lixiviados. Nestas áreas a quantidade de sulfato é relativamente baixa, ferro e alumínio são abundantes e silicio espe cialmente alta. Essa alta concentração de silício é de viđo a decomposição laterítica, frequente nas regiōes tropicais a qual conduz a retirada do silício.

Inicialmente relacionamos as quantidades to tais de material em solução nas äguas do rio Paraná (Jü 
piá), com as estações (Figura 17).

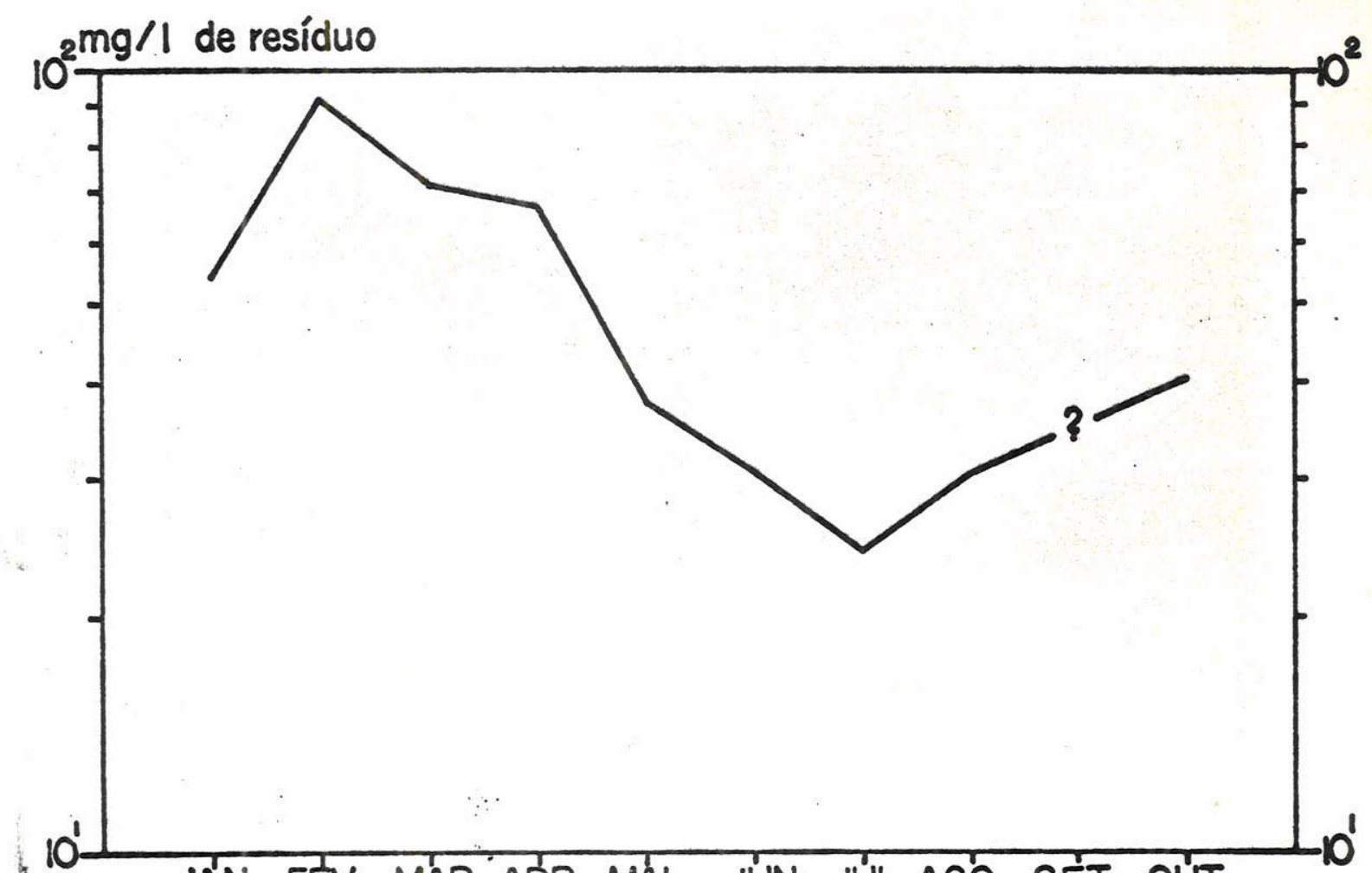

JÁN. FE'V. MAR. ABR. MÁl. JÚN. JÚL.AGO. SE'T. OÚT.

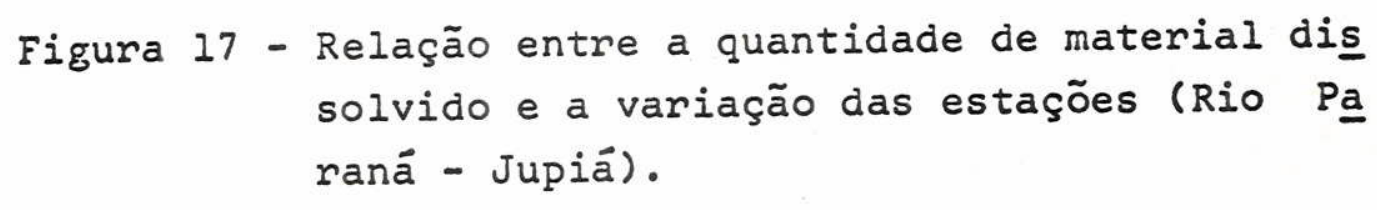

Pela Figura 17 observa-se que a quantidade de material em solução é maior no verão. Êste fato é conträrio aos observados por outros autores, os quais encontraram maiores concentrações de sais em solução nas épocas sêcas. Êste fato pode ser explicado,supon do-se que nas regiões tropicais e subtropicais, as águas superficiais desempenham um papel maior no abas 
tecimento dos rios do que as águas subterrâneas. Assim sendo, essas águas de escoamento seriam responsäveis pela lixiviação dos solos, removendo os sais solúveis acumulados durante a época das sêcas.

Discutiremos a seguir, separadamente, 0 com portamento dos elementos, segundo a variação das estạ ções.

As Figuras 18a e 18b contém os elementos maio res (cátions) em relação a variação sazonal.

Observando as Figuras 18a e $18 \mathrm{~b}$ nota-se pou ca variação dos cátions com as estações, com exceção do silício. Porém, pode-se observar que os elementos sódio, cálcio e magnésio estão em menor concentração no verão (fevereiro) enquanto silicio, ferro e alumí nio, no inverno.

A concentração de silício nas águas é devido a decomposição dos silicatos por processos de intempe rismo químico. Na região de Jupiá as maiores precipi tações ocorrem nos meses de janeiro, fevereiro e março e as menores em agôsto. Como já foi mencionado antes, as chuvas têm capacidade de dissolver os elementos so 
$-73-$
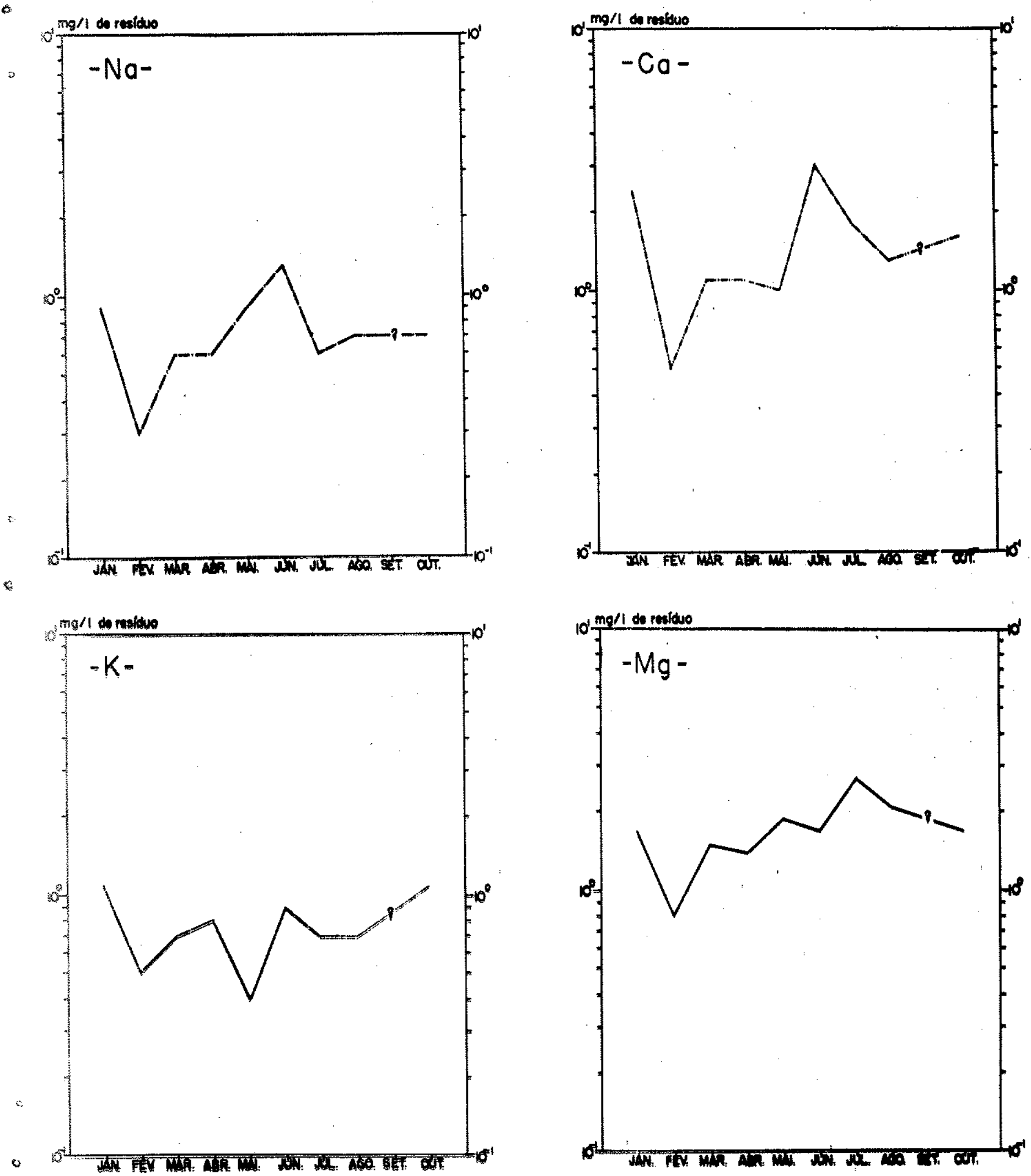

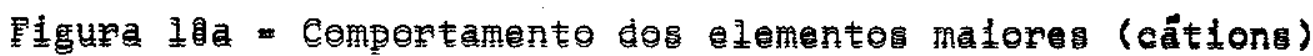

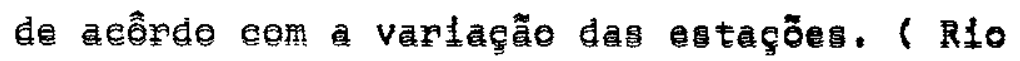

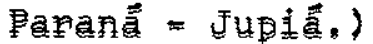


$-74-$

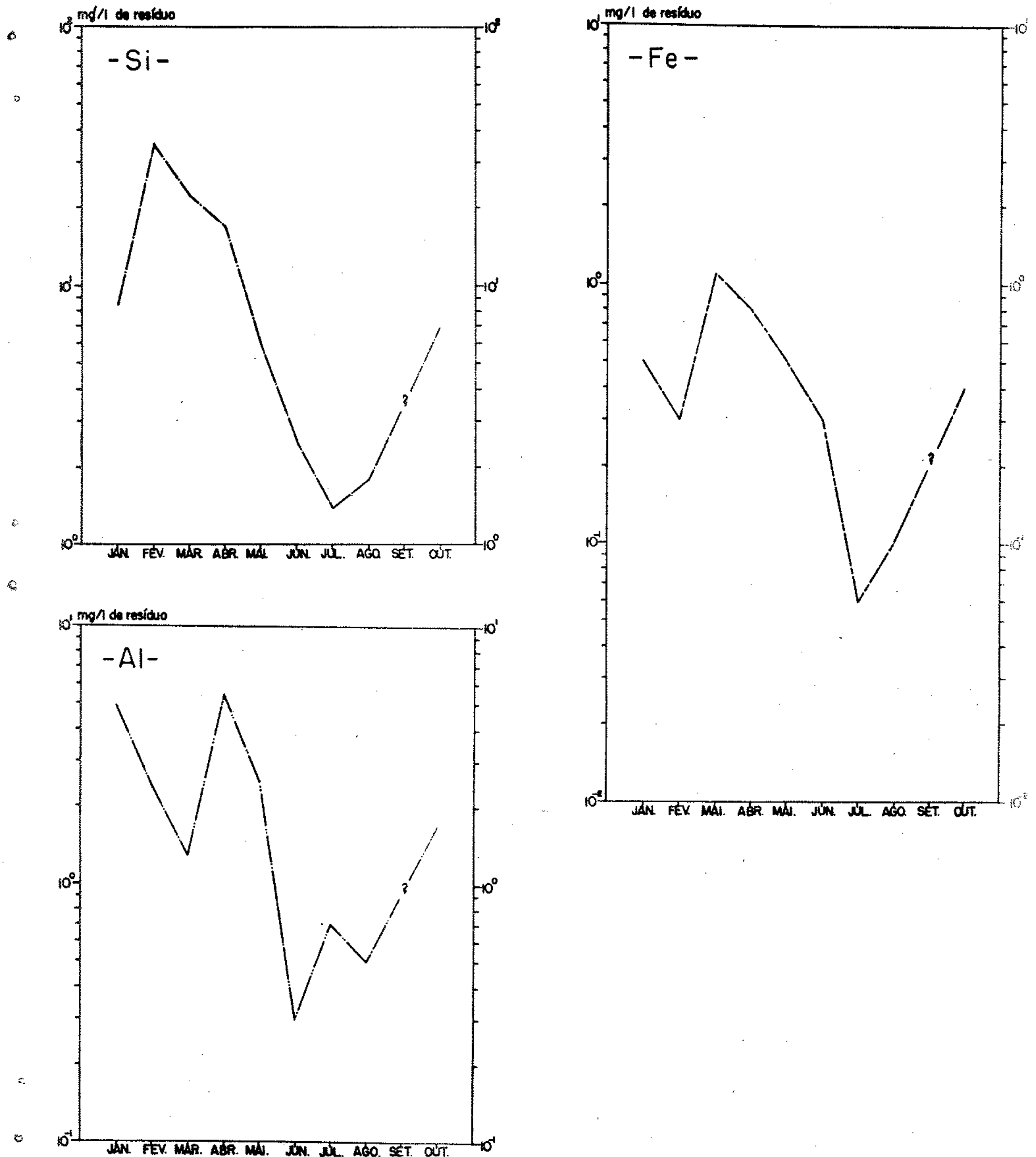

Figura 18b - Comportamento dos elementos maiores (cätions) de acôrdo com a variação das estações. ( Rio Paraná - Jupiá.) 
lūveis os quais são transportados pelas águas de escoa mento para os rios. Foi observado que, a época de pre cipitação máxima em Jupiá, coincide com uma concentrá ção máxima de silício em solução.

Davis (1964), observou que o aumento de tem peratura provoca também um aumento de silício em solu ção, consequentemente, os rios das regiões tropicais possuem quantidades maiores de silício que os das re giões de outros climas. Êste autor sugere ainda, que águas com concentração baixa em silício tem maior quan tidade de cálcio do que águas com alto teor de silício. Nossos dados concordam com a afirmação de Davis. De Villiers (1962), também encontrou concentração máxima de silício no verão. Observando as Figuras 18a e 18b notamos que a maior concentração de cálcio ocorre quan do o silício apresenta valôres mais baixos.

- aluminio ocorre em quantidades apreciáveis nas rochas e solos, porém, como sua mobilidade é peque na, apresenta certa dificuldade de remoção pelas solu ções durante o intemperismo, e fica no resíduo insolü vel. Nota-se concentração menor de alumínio no mês de junho. De uma maneira geral, podemos considerar que todos os elementos com exceção do silício, e talvez fer ro não mostram grande variabilidade de concentração com as estações.

Na Figura 19, estão apresentados os resulta dos das análises dos ânions em relação a variação das estações. 


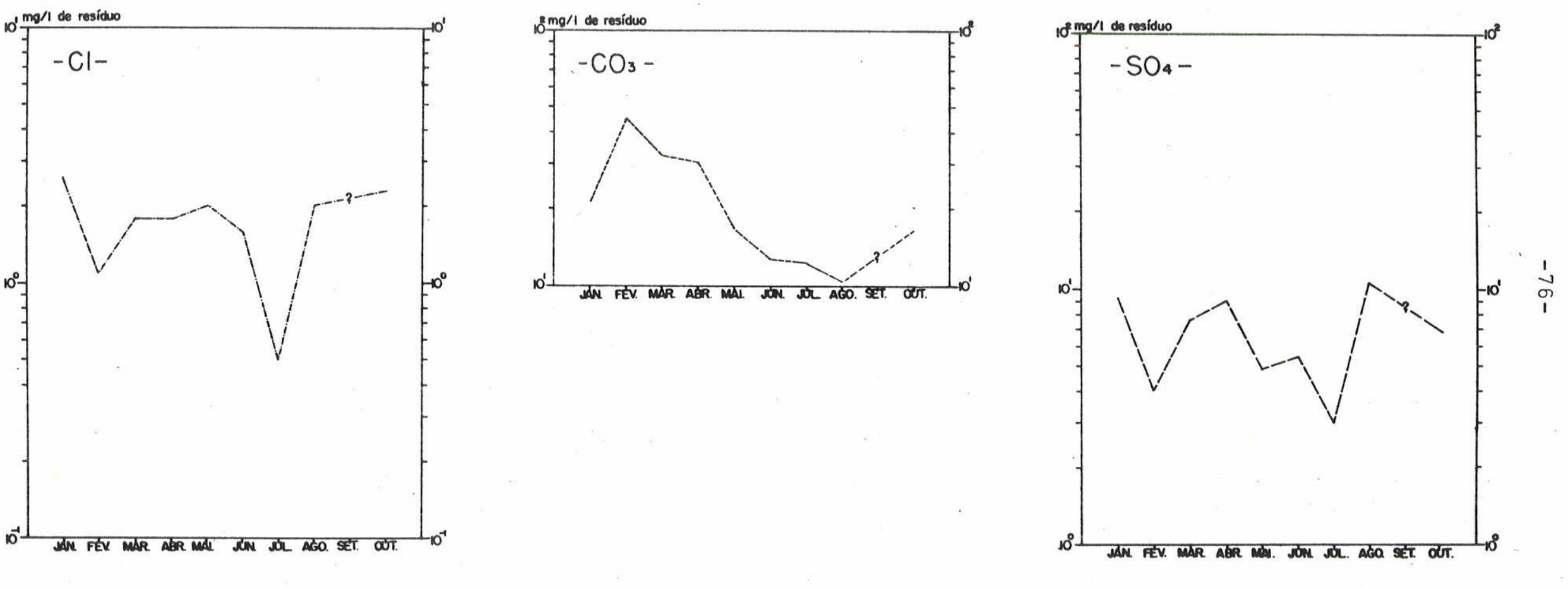

Figura 19 - Comportamento dos elementos maiores (ânions) em relação a variação das estações (Rio Paraná- Jupiá). 
Os cloretos estão presentes em tôdas as águas em menores quantidades do que sulfatos e bicarbonatos. Conway (1942) mostra que $90 \%$ dos cloretos das águas dos rios é cíclico e derivam-se dos oceanos via atmosfera, sendo somente uma pequena parte originada a partir de rochas. Hutton e Leslie (1958) colocaram em düvida a origem marinha do cloreto, via atmosfera. Junge e Werby (1958) mostraram que perto do mar, as águas das chuvas possuem uma concentração de cloretos entre 1 - 8 ppm. Afastando-se da costa, êste teor diminui até 0,08-0,1 ppm e tornando-se progressivamente menor nas águas das chuvas.

A concentração dos cloretos mostra certa va riação com as estações. Na Figura 19 observa-se que em julho, quando a precipitação é mínima em Jupiá, a con centração de cloretos nas águas do rio também é pequena, - que mostra que pelo menos uma parte dêste cloreto pro venha da atmosfera.

Os carbonatos (ou bicabornato recalculado)mos tram concentrações maiores no verão. 'Davis (1964) en controu que äguas com concentrações altas em silicio são também altas em bicarbonato. Na Figura 18b observa-se que o silício está em concentração mais alta em fe vereiro, o mesmo acontecendo com o carbonato (Figura 19).

Os sulfatos mostram certa variação com as di ferentes estações.

o nitrato foi encontrado sömente no mês de ją neiro.

Não existem dados suficientes que permitam comparações dos elementos traços. A única observação talvez válida no presente estudo é que os elementos tra ços não mostram grandes variações com as estações, porém, muito mais com a litologia das äreas drenadas. Êste fa to está de acôrdo com as observações de Konovalov (1959) 
que estudou os elementos traços de quase todos os gran des rios da União Soviética, e concluiu que o clima não tem influência nas concentrações dos mesmos. De Villiers (1962) observou também que os elementos traços variaram pouco durante as estações.

o boro está presente em tôdas as águas na forma de boratos solüveis e sua variação independe das estações, é função da litologia.

o vanádio também foi encontrado em todos os rios (provàvelmente na forma de ion vanadato) e sua concentração varia com os rios, indicando uma dependên cia da litologia. Durante o intemperismo o vanádio é incorporado nos argilo-minerais, tornando as soluções pobres em vanádio.

o cobalto não tem uma distribuição muito va riāvel nas águas dos rios (Kharkar et al., 1968). Du rante o intemperismo o cobalto fica em solução tanto na forma iônica como sob forma de hidróxido coloidal. Durum e Haffty (1963) afirmam que o cobalto e o vaná dio raramente ocorrem nas águas dos rios, em quantidades mesuráveis. No entanto, nas águas dos rios estuda dos éstes dois elementos estão sempre presentes, e sua origen talvez sejam os basaltos nos quais Ruegg (1969) observou altos teores dos mesmos.

o níquel está presente em quase tôdas as ro chàs igneas. Sua concentração varia também com os rios, onde encontra-se sob forma iônica.

o cobre ocorre nas rochas como sulfetos. Du rante 0 intemperismo oxida-se e pode entrar em solução como sulfato. E comum nas águas dos rios, e sua ocor rência é também sob forma iônica. 
2. Relação da concentração dos elementos com a vazão.

Na Figura 20 é apresentada a relação da va zão de alguns rios com a variação das estações.

Dados relativos a vazão dos rios estudados, foram gentilmente fornecidos pelas Centrais Elétricas de São Paulo.

De acôrdo com medidas efetuadas em Jupiá (F gura 20), as vazões máximas do rio Paraná observadas neste ponto, ocorreram no mês de fevereiro dos anos de 1964 e 1970. Em outro ponto de observação déste rio (I Iha Solteira), a vazão mäxima ocorreu nos meses de janeiro e março de 1968. Em ambos os casos, êstes períodos de máxima vazão coincidiram com período de pluviosidade mäxima na área. Anàlogamente, os rios Sucuriú, verde e Pardo, tiveram suas vazões máximas registradas no verão.

O rio Paranapanema apresentou durante $O$ ano de 1970, um comportamento diferente dos rios acima men cionados, ocorrendo sua vazão máxima durante $\circ$ inverno.

A vazão mínima de todos êstes rios no âno de 1970 , ocorreu no fim do inverno. 


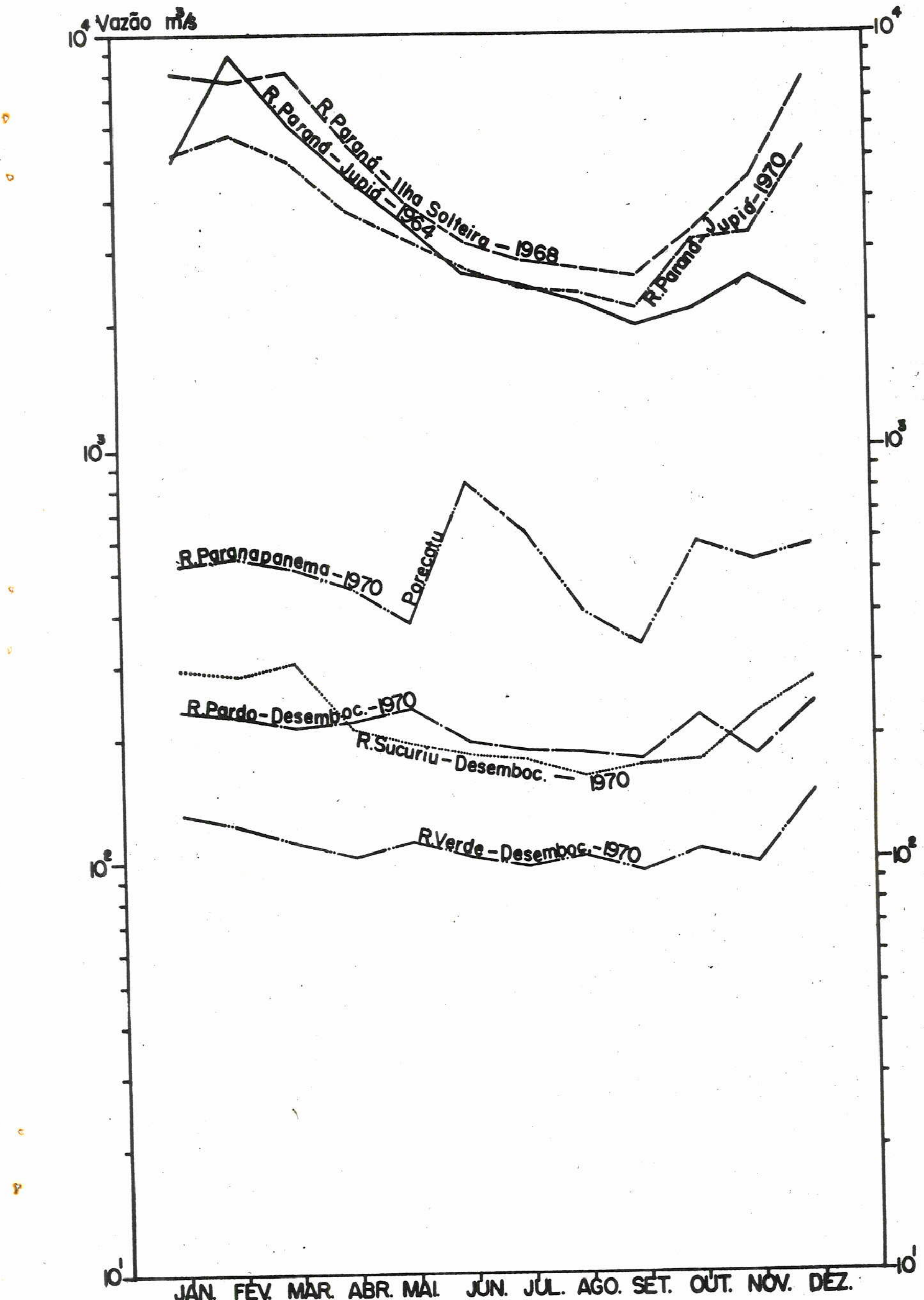

Figura 20 - Relação entre a vazão dos rios Paraná, Tietê, Para napanema, Sucuriú, Verde e Pardo, com a variação das estações. 

solução, e a vazão do rio Paraná (Jupiã) está ilustrada na Figura 21.

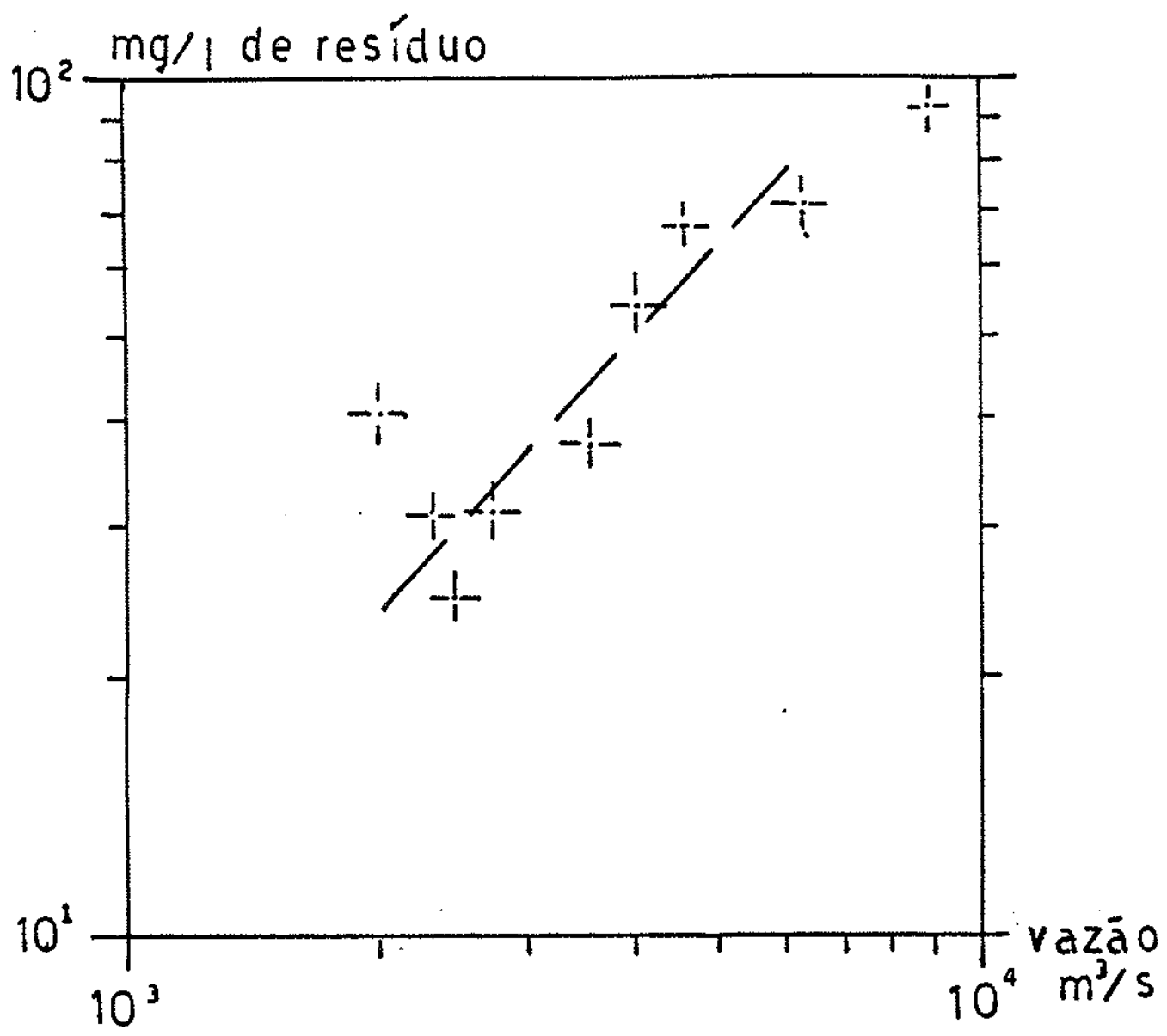
Figura 21 - Relação de material em solu ção e vazão (Rio Paraná -Ju piá, 1964).


Pela Figura 21 observa-se que no rio Paraná (Jupiā), a quantidade máxima de material dissolvido ocon re quando a vazão é máxima. A observação feita por de de Villiers (1962) nas águas do rio Orange, Africa do Sul, é contrária onde a concentração máxima ocorre quan do a vazão é mínima. Pode-se admitir, neste caso, que - fator responsável por essa alta concentração de mate rial em solução, seja o alto teor de silício nas águas.

Nas Figuras 22a e 22b estão apresentados os gráficos de variação de todos os elementos maiores (cátions), com a vazão.

Na Figura 22a observa-se diminuição da concen tração de sódio, cálcio e magnésio com o aumento da vạ zão e apenas uma flutuação na concentração do potássio. o aluminio (Figura 22b) aumenta com o aumento da vazão. De Villiers (1962) observou no rio Orange que valôres grandes de aluminio ocorriam quando a vazão era máxima. Segundo as análises realizadas, o silício móstra uma tendência de aumentar com o aumento da vazão. Davis (1964) afirma que a quantidade total de silício trans portado en solução pelos rios, está diretamente relacio nada com a vazão. O ferro aumenta também com o aumento da vazão.

Na Figura 23 mostramos a relação dos elemen tos maiores (ânions) com a vazão, observando-se uma flu tuação das concentrações do cloreto e sulfato, e um aumento do carbonato, a medida que a vazão aumenta. 
$-83-$
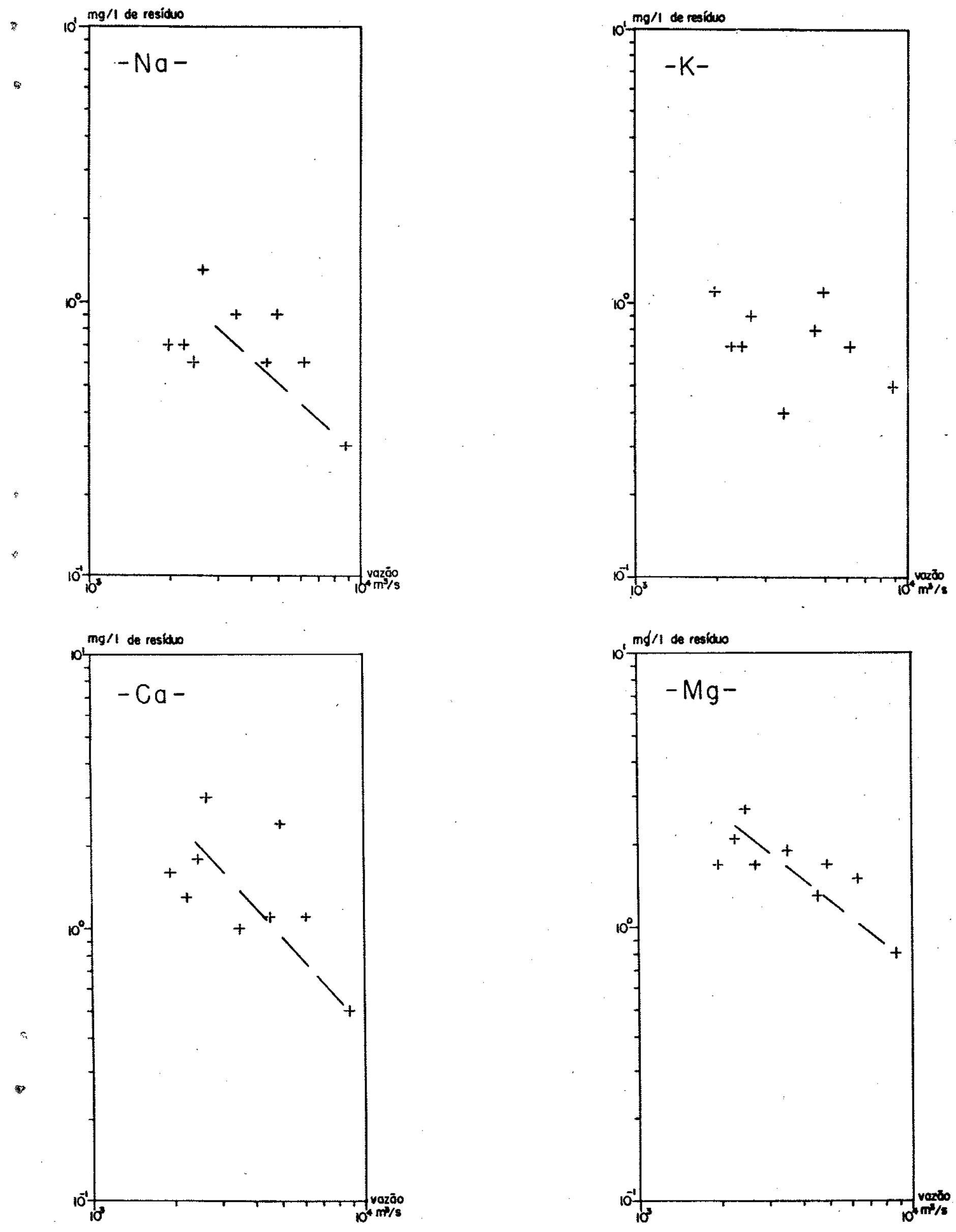

Figura 22a - Relação dos elenentos maiores (cätions) com a vazão. (Rio Paraná - Jupià, 1964.) 

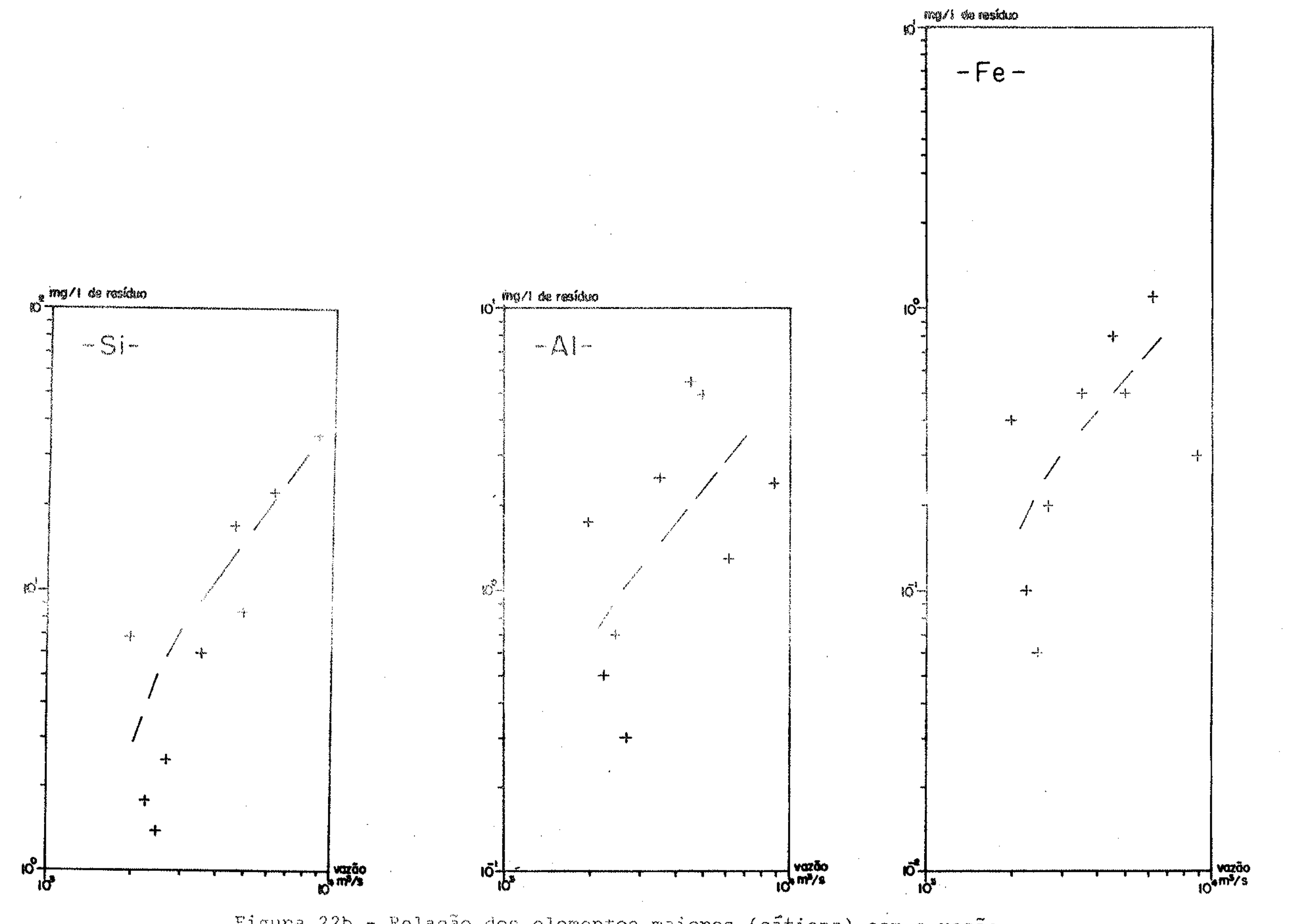

Figura 22b - Relacăo dos elementos maiores (câtions) con a vazão

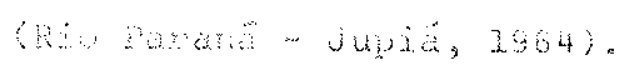



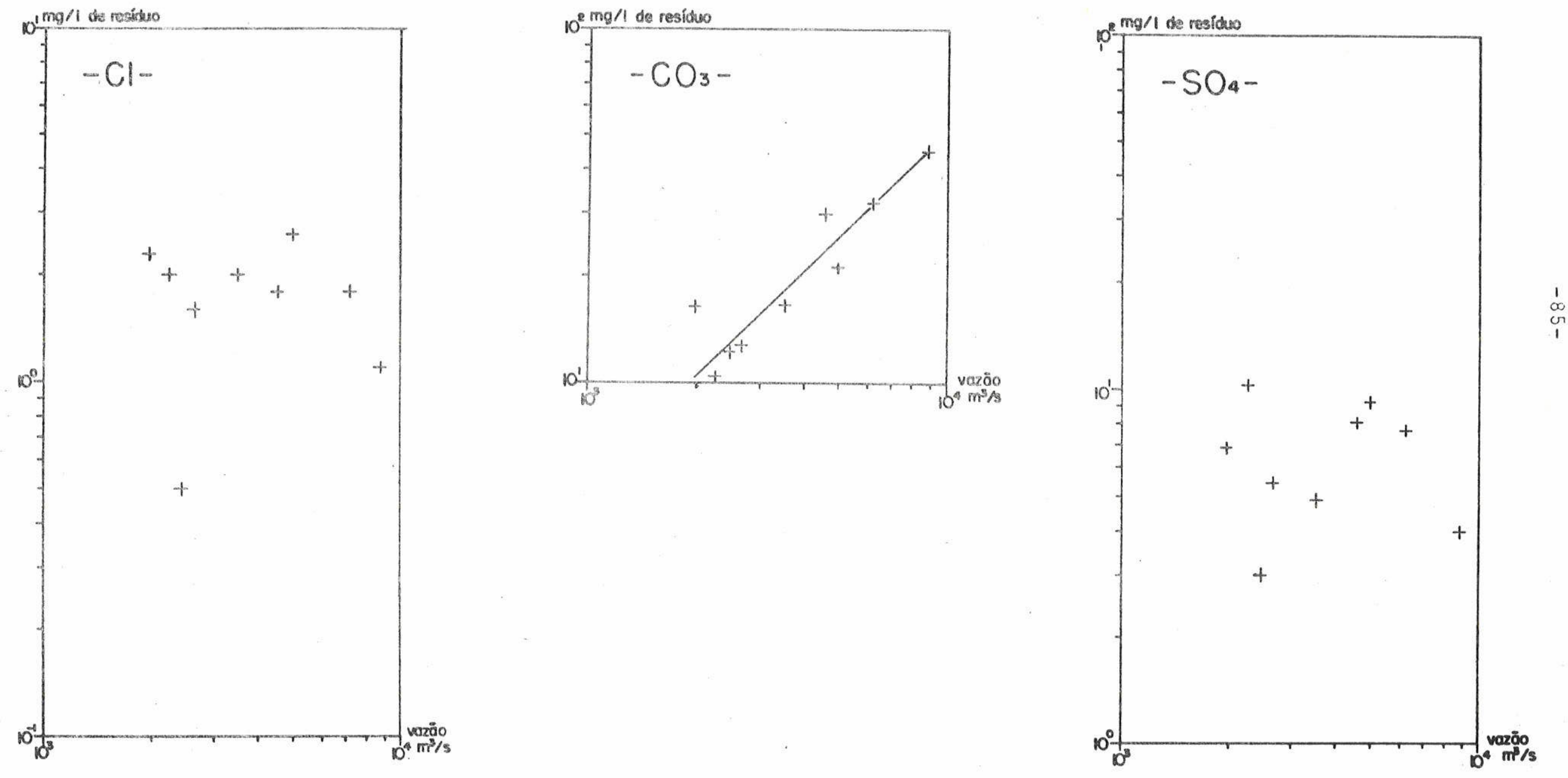

Figura 23 - Relação dos elementos maiores (ânions) com a vazão (Rio Paranä - Jupiá, 1964). 


\begin{abstract}
$-86-$
Os dados existentes são insuficientes para explicarem o comportamento dos elementos traços em re lação a vazão. Durum e Haffty (1963) afirmam que não existe correlação entre vazão e concentração dos ele mentos traços.
\end{abstract}

3. Relação da concentração dos elementos com $\circ \mathrm{pH}$.

0 pH das águas dos rios foi medido no momen to da chegada das amostras no laboratório. Segundo Schuetle e Elsworth (1954), O pH varia durante $\circ$ dia, acusando um valor máximo no por do sol e um mínimo no amanhecer.

Durante o dia, no processo de fotossintese, as plantas retiram dióxido de carbono da água, para fá bricar os carbohidratos e eliminam o oxigênio. Durante a noite, entretanto, o processo de respiração das plan tas e animais provoca um resultado inverso, eliminando $\mathrm{CO}_{2}$ e absorvendo $\mathrm{O}_{2}$.

Em seguida, apresentamos o comportamento dos elementos maiores (cátions) em relação ao pH das águas de todos os rios estudados.

Como nas águas dos rios existe pouca varia ção do $\mathrm{pH}$, o qual é aproximadamente neutro, pouco se pode concluir a respeito da variação dêste fator. 
$-87-$
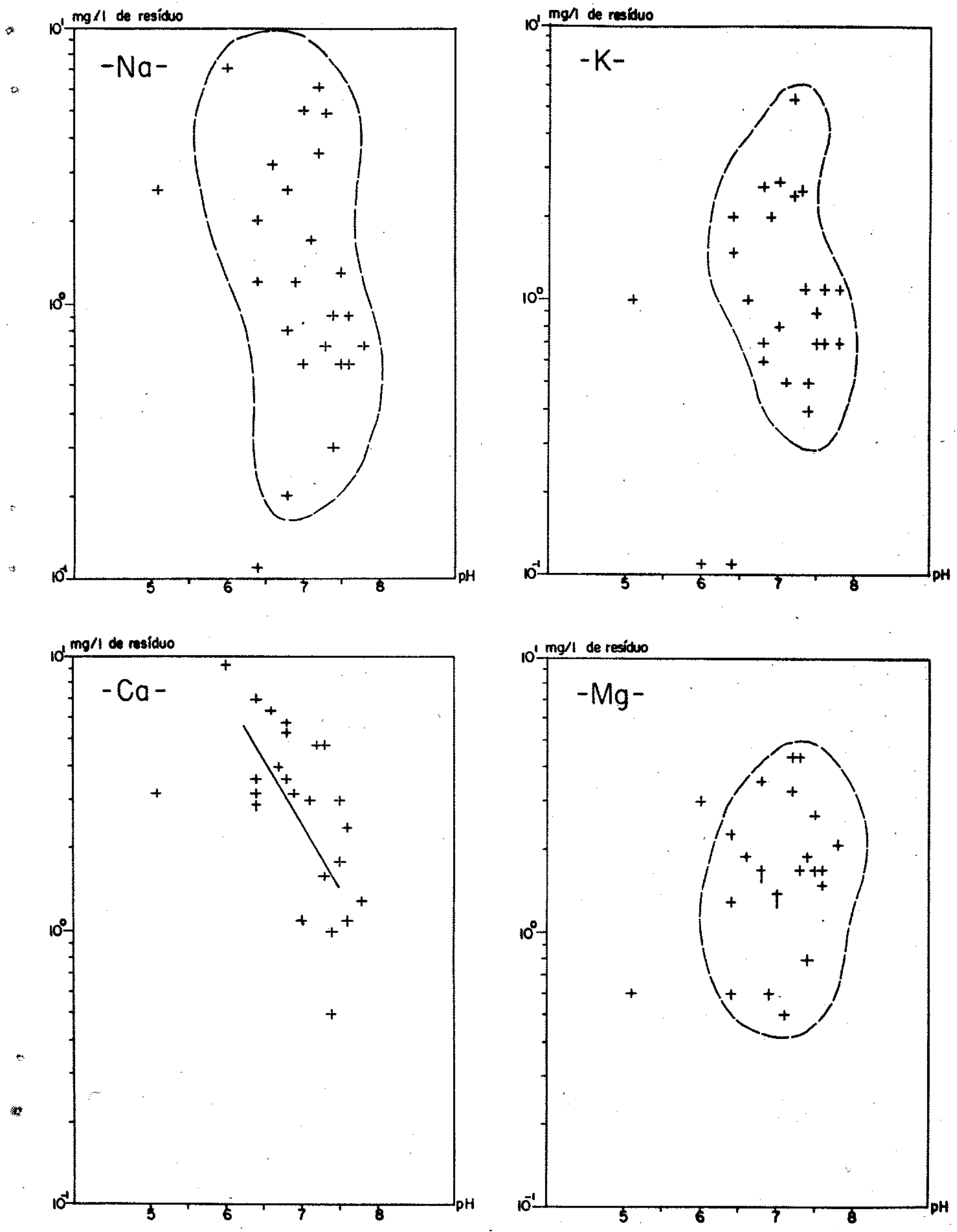

Figura $24 a$ - Relação dos elementos maiores (cátions) com $\circ \mathrm{pH}$. 
$-88-$
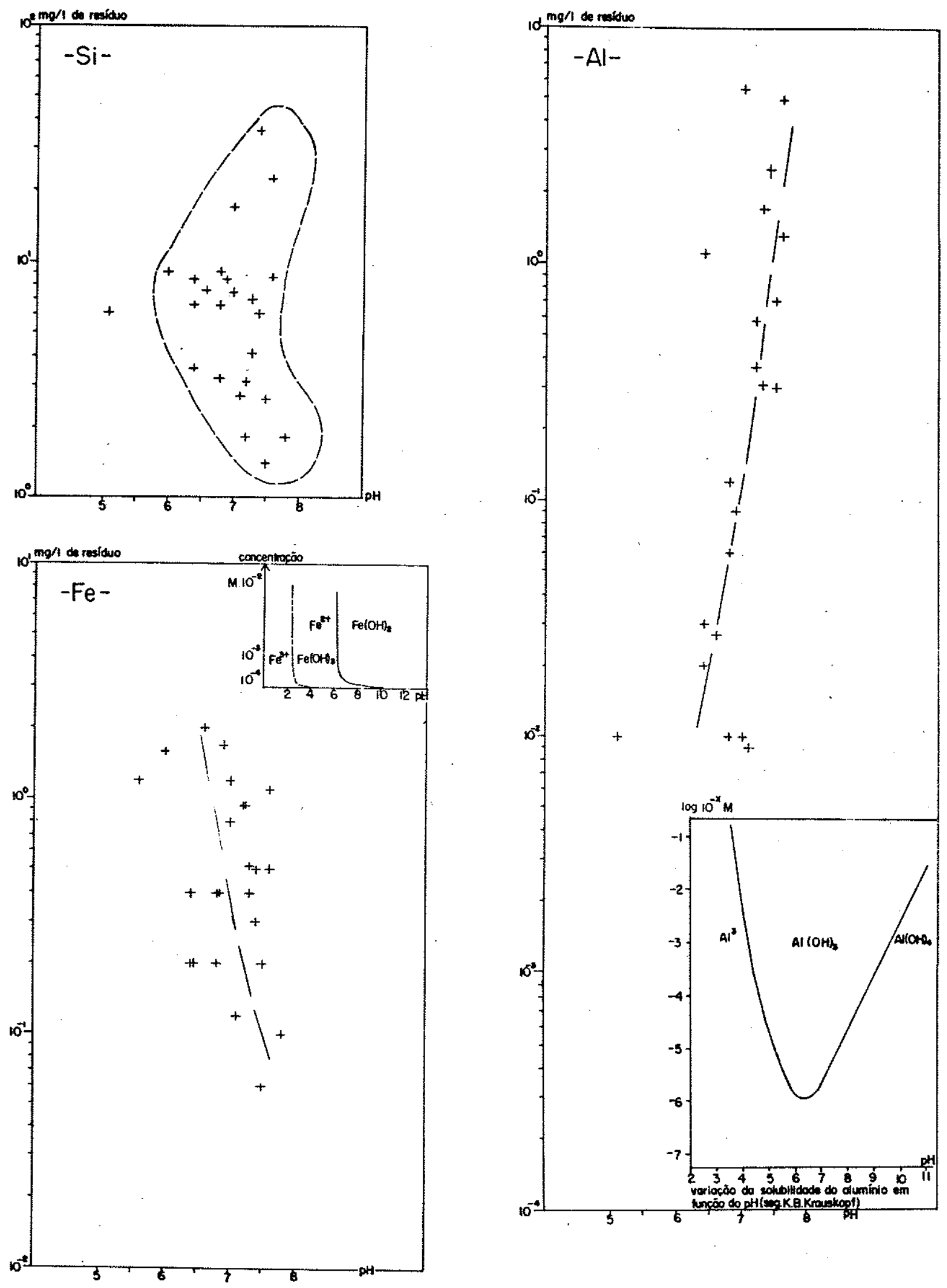

Figura 24b - Relação dos elenentos maiores (cátions) com $\circ$ pH. 
As concentrações do sódio, potássio e magné sio não variam com $\circ \mathrm{pH}$. A solubilidade do magnésio é máxima com $\circ \mathrm{pH}$ entre 7 e 7,3, e sua precipitação sob forma de hidróxido ocorre para pH próximo a 10. Pela Figura $24 a$ nota-se certa tendência da concentração do cálcio diminuir quando o pH aumenta.

No caso do silício (Figura 24b) nota-se uma certa variação da concentração em solução com o aumento do $\mathrm{pH}$. Correns (1941) encontrou dados para afirmar que a solubilidade do silício aumenta fortemente em $\mathrm{pH}$ acima de 5. Mas na Figura 24b, observa-se que a concentração do silício varia bastante com $\circ \mathrm{pH}$, sem mostrar qualquer tendência.

- ferro mostra certa tendência de diminuir com o aumento do $\mathrm{pH}$. O ion ferroso é fàcilmente dis solvido em água contendo dióxido de carbono, formando-se bicarbonato ferroso $\mathrm{Fe}\left(\mathrm{HCO}_{3}\right)_{2}$, o qual fica parcial mente dissociado em soluções aquosas. Quando o dióxí do de carbono é retirado da água, por exemplo, durante a fotossintese das plantas, pode ocorrer precipitação do $\mathrm{FeCO}_{3}$ (carbonato ferroso). A precipitação do hidró xido férrico começa com $\mathrm{pH}^{3} 3$, e do hidróxido ferroso com $\mathrm{pH} 5,1$.

0 aluminio pode ficar dissolvido tanto em solução ácida ( $\mathrm{pH}$ menor que 4) como em solução básica ( $\mathrm{pH}$ maior que 9). O hidróxido de alumínio $\mathrm{Al}(\mathrm{OH})_{3}$ pre cipita-se próximo de $\mathrm{pH}$ neutro. Clarke (1924) mostra que as águas dos rios contém alumínio desde traços até quantidades de $4 \mathrm{ppm}$. A existência de matéria orgâní ca possibilita a presença de alumínio em solução, não 
sòmente sob forma iônica, como também constituindo com postos orgânicos. Pela Figura $24 \mathrm{~b}$ observa-se que exis te mais alumínio em solução com o aumento do pH.

Na Figura 25 encontram-se as relaçōes das con centrações dos elementos maiores (ânions) em relação ao $\mathrm{pH}$ do meio, na qual não se observa tendência para variação nas concentrações dos cloretos e carbonatos com variação do $\mathrm{pH}$.

Os sulfatos mostram uma tendência de aumen tar sua concentração com o aumento do pHi.

Considerando os poucos dados, desde que os nitratos não foram encontrados em tôdas as águas, pode mos verificar que não houve variação das concentrações variando o pH. O nitrogênio está presente na água da chuva. A quantidade de $\mathrm{NO}_{3}$ nas águas das chuvas, de acôrdo com Rankama e Sahama (1949), varia de 0 - 6 pprn. os nitratos não variam com as estações, vazão e pH das águas dos rios.

Nas Figuras $26 \mathrm{a}$ e $26 \mathrm{~b}$ relacionamos a concen tração dos elementos traços com o pH. 
$-91-$
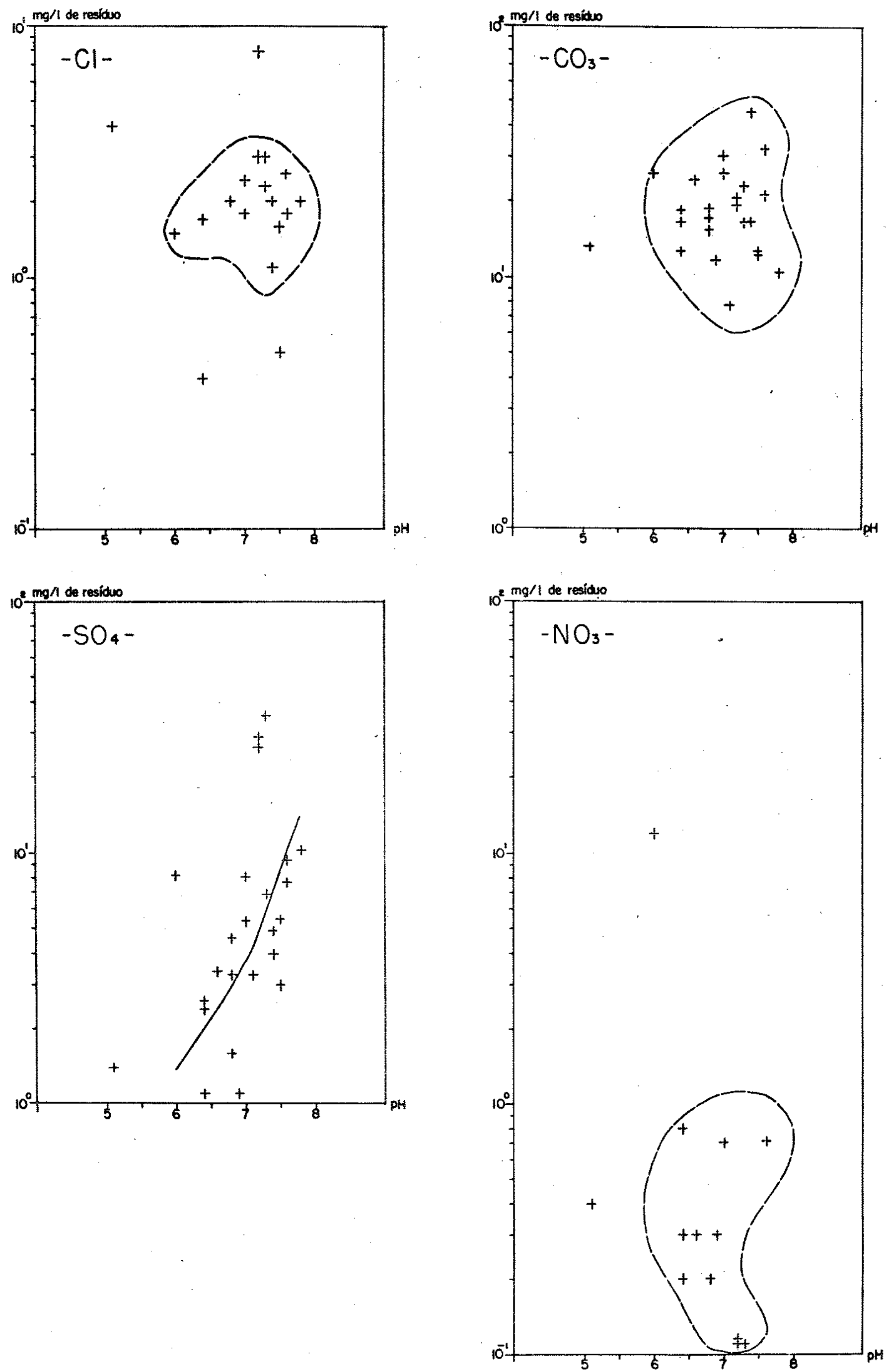

Figura 25 - Relação dos elementos maiores (ânions) com o pH. 

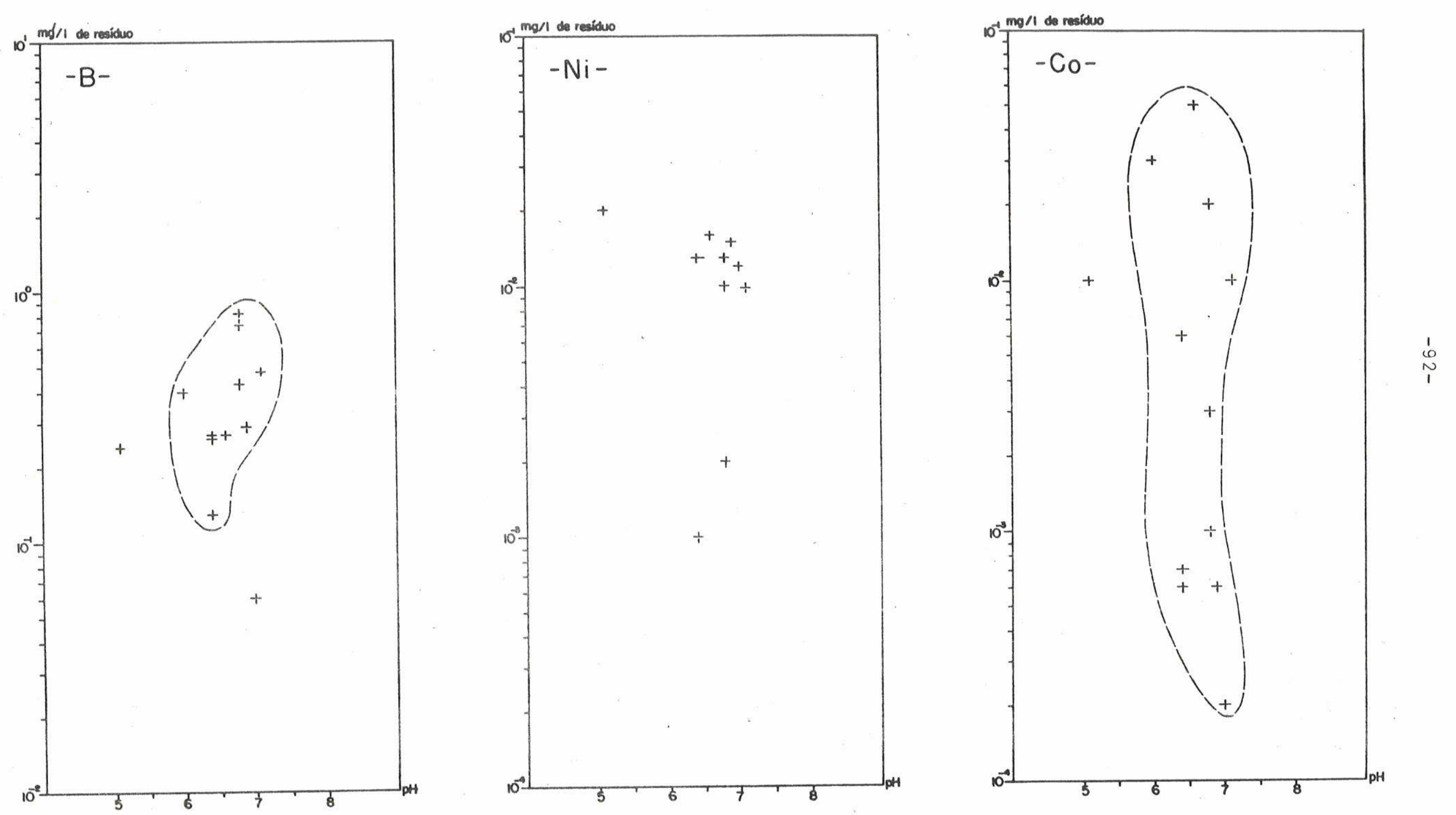

Figura 26a.-- Relação dos elementos traços com o pH. 


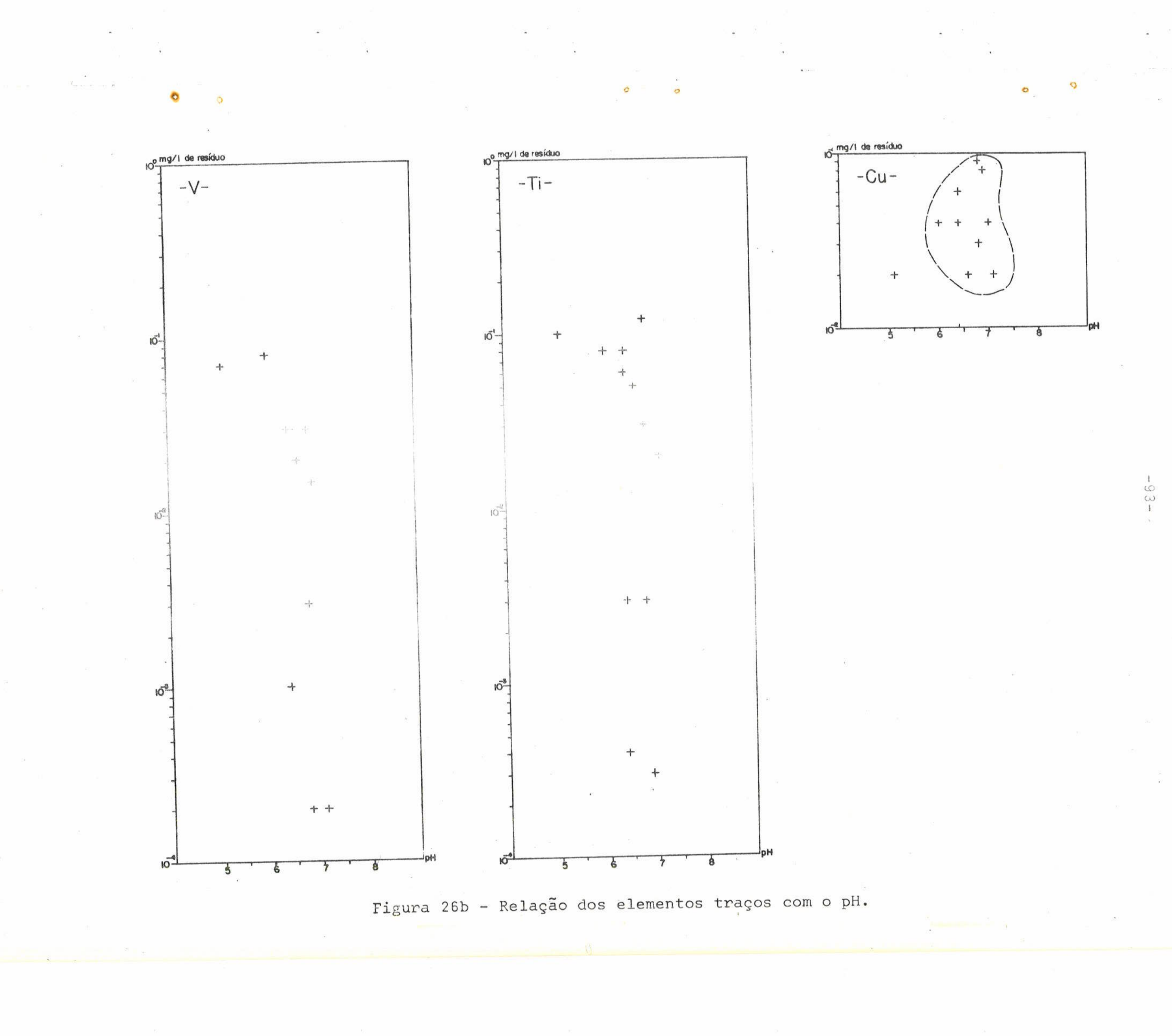


As concentrações dos elementos traços variam com $\circ \mathrm{pH}$, porém a distribuição dos valôres obtidos nas análises, não indicam tendência de aumento ou diminuí ção.

Na Figura 27 relacionamos $\circ \mathrm{pH}$ das águas es tudadas com a vazão de alguns rios, odservando-se que - pH é baixo quando a vazão é baixa e vice-versa.

d - Classificação das đ̊guas dos rios estudados.

Nia Figura 28 comparamos as médias das concen trações dos carbonatos, sulfatos, cloretos e nitratos dos rios estudados, onde verifica-se que em todos os rios os carbonatos predominam sôbre sulfatos, cloretos e nitratos. Assim podemos classificar as águas dos rios estudados em águas carbonáticas, o que aliás, é mais comum, especialmente em climas tropicais e subtro picais, devido a abundância de água de precipitação rí ca em ácico carbônico. (Nas soluções existe $\circ \mathrm{HCO}_{3}$, mas durante a evaporação da água no laboratório para análises de obtenção de resíauo, ocorre a decomposição do bicarbonato e formação de carbonato.)

o sulfato é quimicamente estável na maioria. dos ambientes naturais, sendo comum nas águas dos rios em concentrações pequenas.

o nitrato está presente em pequenas quantida 


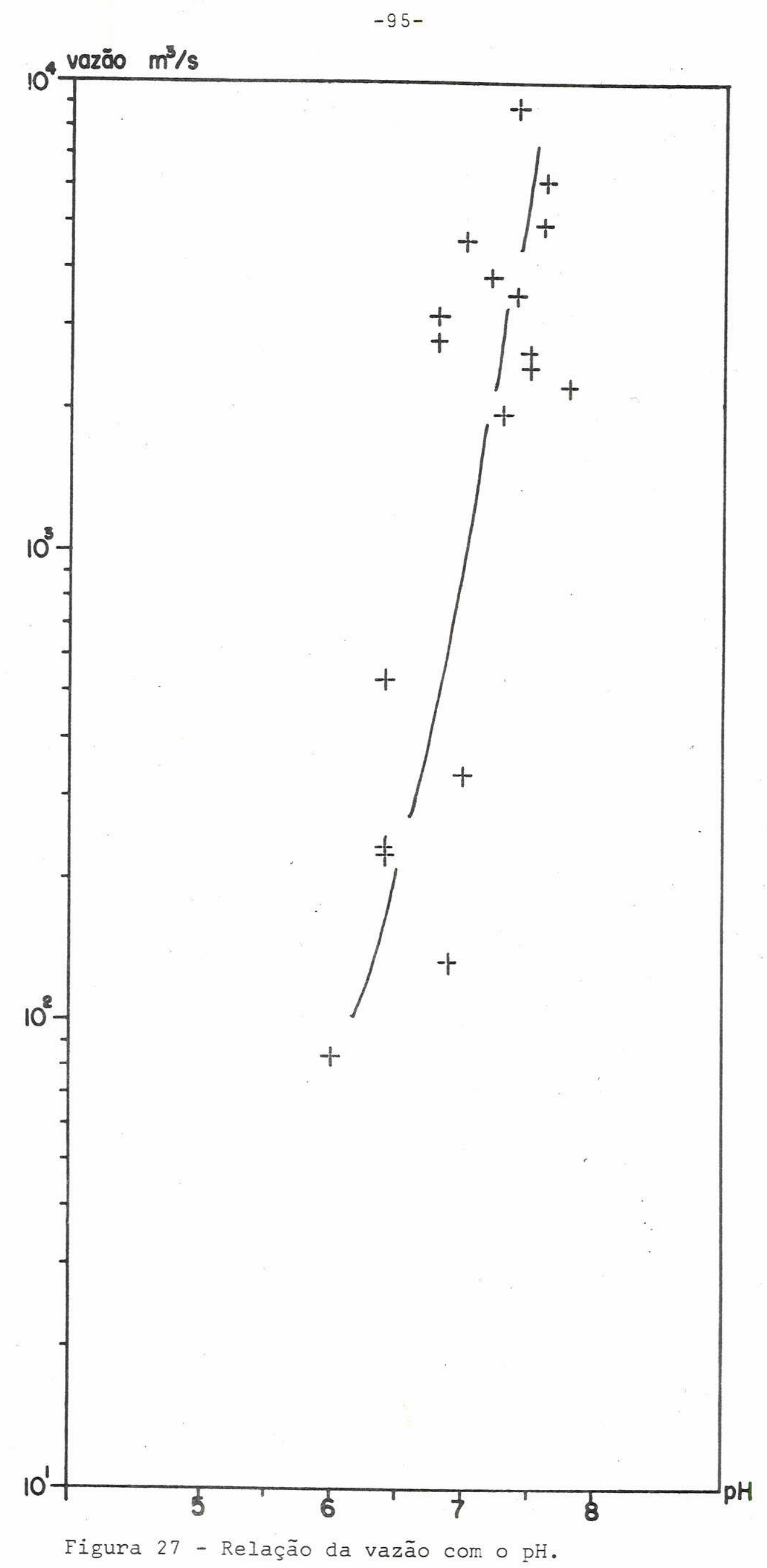




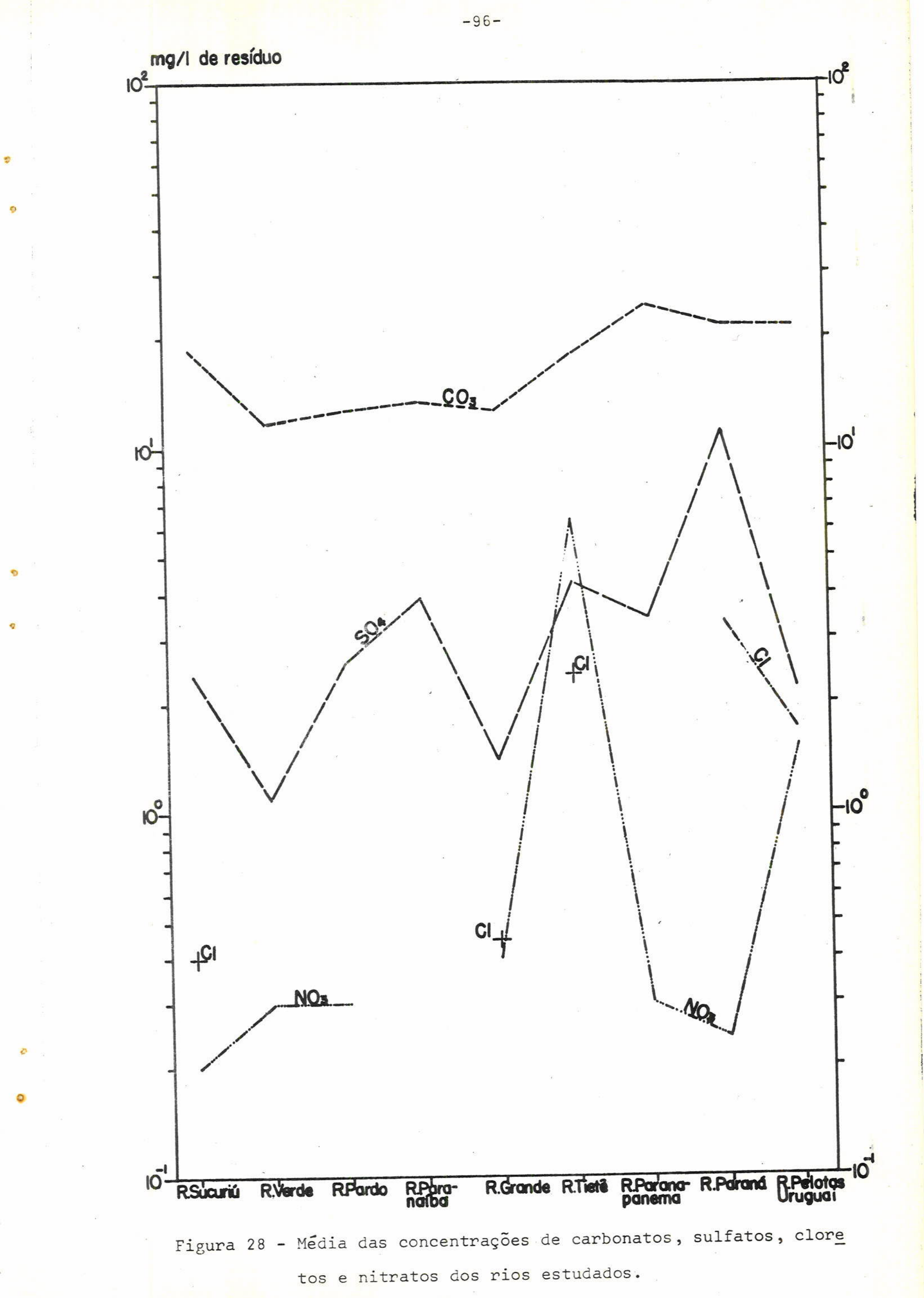


des nas águas dos rios. Nitritos, nitratos e amônia originam-se das águas das chuvas.

Em relação a concentração dos cloretos, ob servou-se certa diminuição nas amostras coletadas em rios mais distantes do mar. Sabe-se que os cloretos são os constituintes mais abundantes das águas das chu vas. O conteúdo de cloretos nas águas das chuvas que caem nos continentes é de $0,33 \mathrm{ppm}$ (Collins e Williams, 1933). Quando existem valôres mais altos, a contribui ção pode vir do mar. os pingos de água do mar ficam suspensos no ar e são capazes de aí permanecerem até que se condensem e se precipitem sob forma de chuva. 0 conteúdo do ar em cloretos, perto do mar, é de 0,076 a $0,518 \mathrm{mg} \cdot \mathrm{m}^{-3}$, de acôrdo com Jacobs (Rankama e Sahama, 1949, pág. 314). 
V. QUANTIDADE TOTAL DE MATERIAL DISSOLVIDO E TRANSPOR TADO PELOS RIOS.

a - Quantidade de material dissolvido por ano.

Relacionando-se os dados da área drenada pelos rios e seus afluentes, com a vazão e a quantidade de material dissolvido, foram elaboradas as Tabelas 27 , $28,29,30,31$ e 32 . Êstes dados são referentes aos rios Sucuriú, Verde, Pardo, Tietê, Paranapanema e Para ná, respectivamente, nas quais foram calculadas as quan tidades de material em solução por segundo, dia e mês. Onde não existem dados de vazão para $\circ$ ano inteiro,fêz-se uma aproximação da quantidade de material dissolvi do por ano. 
TABELA 27

Cálculo de quantidade de material dissolvido

Rỉ Sucuriú - Pôsto № SC, 1.F. da C.E.S.P.

Area drenaute Vazãr $\mathrm{m}^{3} / \mathrm{s}$ Quant.de sais quant.de mat. Quant.de mat. Quant.de mat. Quant.de mat.

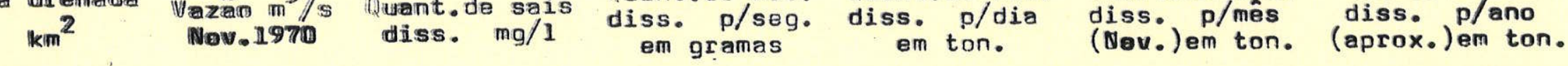

23.850

227

37,0
2,0
1,5
3,6
1,3
6,5
0,2
0,02
0,4
18,6
2,4
0,2
0,13
0,001
0,0007
0,06
0,0004
0,0006
0,01

$\begin{array}{cc}8.399 & 725 \\ 454 & 39 \\ 340 & 29 \\ 817 & 70 \\ 295 & 25 \\ 1.475 & 127 \\ 45 & 3 \\ 4 & 0,3 \\ 90 & 7 \\ 4.220 & 364 \\ 544 & 47 \\ 45 & 3 \\ 29 & 2 \\ 0,2 & 0,02 \\ 0,1 & 0,01 \\ 13 & 1 \\ 0,09 & 0,007 \\ 0,1 & 0,01 \\ 2 & 0,2 \\ & \end{array}$

21.771
1.177
883
2.118
765
3.825
118
12
236
10.945
1.412
118
76
0,6
0,4
35
0,2
0,3
6

264.880

14.319

10.738

25.773

9.308

46.538

1.432

143
2.865

2.865

133.169

17.181

1.432

Total

$\mathrm{Na}$

$\mathrm{Na}$

Ca

$\mathrm{Mg}$

$\mathrm{Mg}$

$\mathrm{Fe}$

Al

$\mathrm{CO}_{3}$

$\mathrm{SO}_{4}$

$\mathrm{NO}_{3}$

$931 \quad B$

$5 \quad \mathrm{Ni}$

$430 \quad \mathrm{CO}$

$T_{i}$

Mn 
TABELA 28

Cálculo da nuantidade de material dissolvido

Rio Verde - Pôsto No Ve.J.F. da C.E.S.P.

Área drenada quant, de mat. Quant.de mat. Muant.de mat. Quant.de mat.

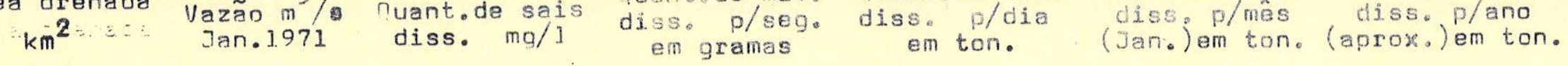

\begin{tabular}{|c|c|c|c|c|c|c|c|}
\hline \multirow[t]{18}{*}{21.800} & 132 & 31,0 & 4.092 & 353 & 10.616 & 129.222 & Total \\
\hline & & 1,2 & 158 & 13 & 410 & 4.997 & $\mathrm{Na}$ \\
\hline & & 2,0 & 264 & 22 & 684 & 8.326 & k \\
\hline & & $3, ?$ & 422 & 36 & 1.095 & 13.323 & $\mathrm{Ca}$ \\
\hline & & 0,6 & 79 & 6 & 205 & 2.497 & $\mathrm{Mg}$ \\
\hline & & 8,4 & 1.108 & 95 & 2.874 & 34.967 & $\mathrm{Si}$ \\
\hline & & 1,7 & 224 & 19 & 581 & 7.077 & $\mathrm{Fe}$ \\
\hline & & 0,09 & 11 & 1 & 30 & 376 & $A 1$ \\
\hline & & 11,9 & 1.570 & 135 & 4.071 & 49.537 & $\mathrm{CO}_{3}$ \\
\hline & & 1,1 & 145 & 12 & 376 & 4.581 & $\mathrm{SO}_{4}$ \\
\hline & & 0,3 & 39 & 3 & 103 & 1.248 & $\mathrm{NO}_{3}$ \\
\hline & & 0,29 & 38 & 3 & 99 & 1.208 & B \\
\hline & & 0,015 & 1 & 1 & 51 & 624 & v \\
\hline & & 0,0006 & 0,07 & 0,006 & 0,2 & 2 & $\mathrm{Ni}$ \\
\hline & & 0,03 & 3 & 0,3 & 10 & 125 & Co \\
\hline & & 0,0003 & 0,03 & 0,003 & 0,1 & 1 & $T i$ \\
\hline & & 0,08 & 10 & 0,9 & 27 & 333 & $\mathrm{Cu}$ \\
\hline & & $0,00002 ?$ & $0,002 ?$ & $0,0002 ?$ & $0,006 ?$ & $0,08 ?$ & $B i ?$ \\
\hline
\end{tabular}


TABELA 29

Cálculo da muantidade de material dissolvido

Rio Pardo - Pôsto No Pmt 1. F.

Area drenada

Vazão $\mathrm{m}^{3} / \mathrm{s}$
Tan.1971

nuant.de sais
diss.mg/l

Tuant.de mat. Wuant.de mat. Tuant.de mat. Quant.de mat.

diss. p/ano Elementos

$\mathrm{km}^{2}$.

$$
32,0
$$

1,2

3,2

3,2
0,6

8,4

0,4

0,03

12,6

$?, 6$

0,3 .

0,26

0,03

0,0006

0,03
0,08

0,0005

0,06

om aramas

$\begin{array}{cc}\text { em aramas } & \text { em ton. } \\ 7.424 & 641 \\ 278 & 24 \\ 464 & 40 \\ 742 & 64 \\ 139 & 12 \\ 1.949 & 168 \\ 9 ? & 8 \\ 6 & 0,6 \\ 2.923 & 252 \\ 603 & 52 \\ 69 & 6 \\ 60 & 5 \\ 6 & 0,6 \\ 0,1 & 0,01 \\ 6 & 0,6 \\ 18 & 1 \\ 0,1 & 0,01 \\ 13 & 1 \\ & \end{array}$

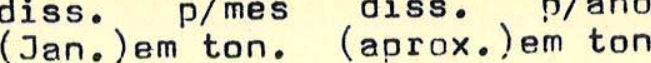

\begin{abstract}
19.242
\end{abstract}
721

1.203

1.924

361
5.052

241

18
7.575

1.564

180

234.111

8.778

14.633

23.411

4.391

61.466

2.927

219

92.169

19.024

2.194

1.902

18

0,3

18

48

36

Total

$\mathrm{Na}$

K

$\mathrm{Ca}$

Fe

Al

$\mathrm{CO}_{3}$

$\mathrm{SO}_{4}$

$\mathrm{NO}_{3}$

219 V

$4 \mathrm{Ni}$

219 Co

$587 \sim T i$

$439 \quad \mathrm{Cu}$ 


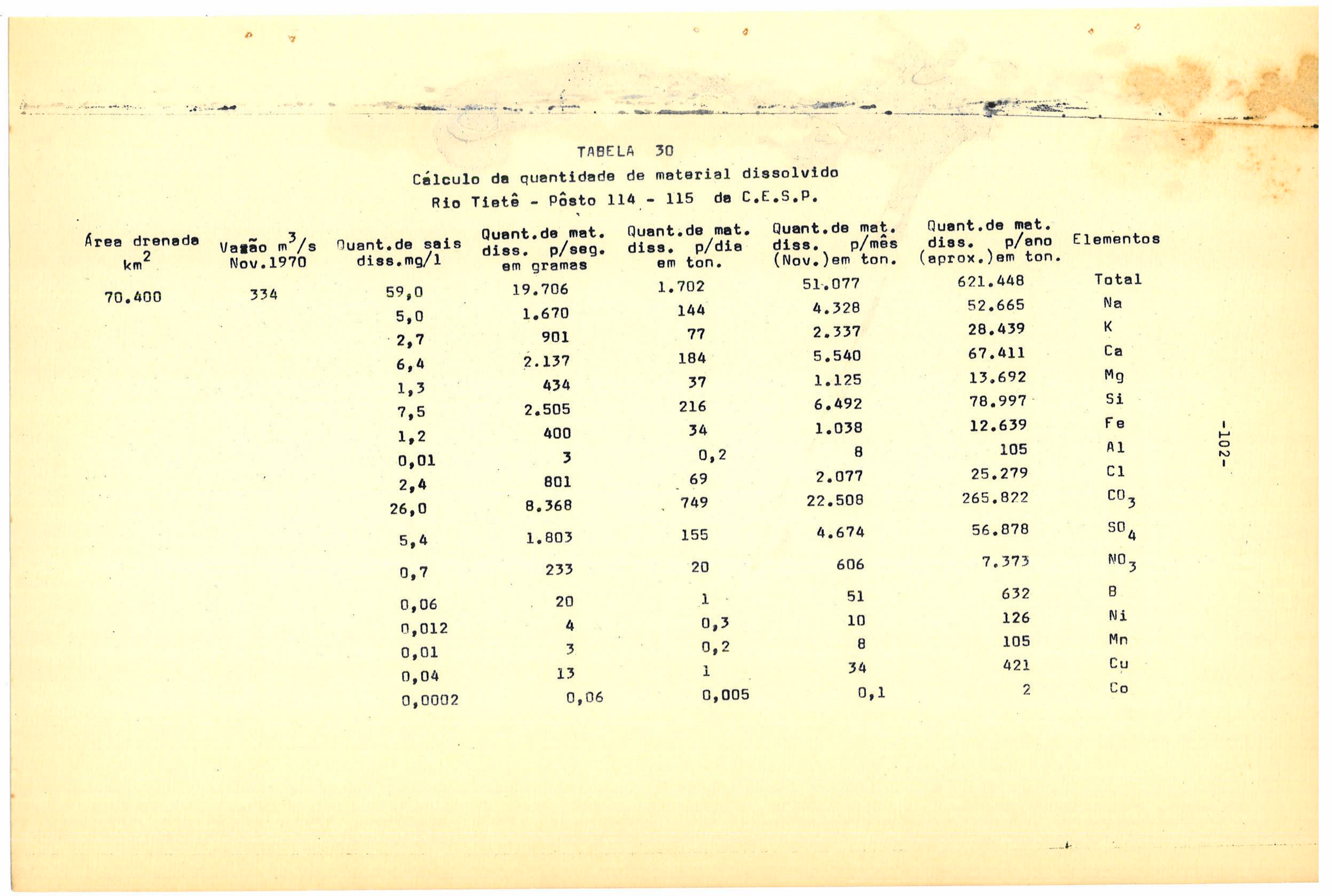


TABELA 31

Cálculo da quantidade de material dissolvido

Rio Paranapanema - Pôsto № Pp. 2.F. da C.E.S.P.

Area drenada $\mathrm{km}^{2}$

83.200 Vazão $\mathrm{m}^{3} / \mathrm{s}$ Quant.de sais
Nov.1970 diss.mg/l

537

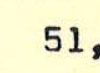

Nuant.de mat. Duant.de mat
diss. p/seg. diss. em gramas diss. p/dia

51,0
3,2

1,0

6,4

1,9

7,5

2,0
0,27

24,4
3,4

0,3

0,27

0,02

0,05

0,06

0,05

0,02
28.998

1.718

3.437

1.020

4.028

1.074

145

13.102

1.826

161

149

14

26

32

26

14
2.365

148

46

296

88

348

92

1.132

158

13

12 Quant.de mat.
diss. p/mant.de mat. Nov.) em ton. (aprox.) em ton.

$\begin{array}{rrl}75.150 & 914.325 & \text { Total } \\ 4.440 & 54.020 & \mathrm{Na} \\ 1.392 & 16.936 & \mathrm{~K} \\ 8.880 & 108.040 & \mathrm{Ca} \\ 2.643 & 32.157 & \mathrm{Mg} \\ 10.440 & 127.020 & \mathrm{Si} \\ 2.784 & 33.872 & \mathrm{Fe} \\ 375 & 4.563 & \mathrm{Al} \\ 33.973 & 458.193 & \mathrm{CO}_{3} \\ 4.740 & 57.670 & \mathrm{SO}_{4} \\ 417 & 5.074 & \mathrm{NO}_{3} \\ 387 & 4.708 & \mathrm{~B} \\ 37 & 456 & \mathrm{~V} \\ 69 & 850 & \mathrm{Ni} \\ 83 & 1.014 & \mathrm{Co} \\ 69 & 850 & \mathrm{Ti} \\ 37 & 456 & \mathrm{Cu}\end{array}$


$-104-$
TABELA 32

Cálculo da quantidade de material dissolvido

rea drenada Vazzão Data Quant.de sais Duant.de mat. Quant.de mat. Quant.de (Rio Paraná - Jupiá - Pôsto no Pa - 2L)

\begin{tabular}{|c|c|c|c|c|c|c|c|c|c|c|c|c|c|c|c|c|c|c|c|c|c|c|c|}
\hline 470.000 & 4940 & $\operatorname{Jan} .1964$ & 54,2 & 267 & 23.133 & 694.008 & $\begin{array}{c}\mathrm{Na} \\
11.524\end{array}$ & $\begin{array}{c}K \\
14.084\end{array}$ & $\begin{array}{c}\mathrm{Ca} \\
30.730\end{array}$ & $\begin{array}{c}M_{g} \\
21.768\end{array}$ & $\begin{array}{c}\text { Si } \\
108.832\end{array}$ & $\begin{array}{c}F e \\
6.402\end{array}$ & $\begin{array}{c}A_{1} \\
62.742\end{array}$ & $\begin{array}{c}C_{1} \\
33.292\end{array}$ & $\begin{array}{c}\mathrm{CO}_{3} \\
271.454\end{array}$ & $\begin{array}{r}\mathrm{SO}_{4} \\
\mathrm{r}\end{array}$ & ( & B & v & $\mathrm{Ni}$ & Co & $T i$ & $\mathrm{Cu}$ \\
\hline & 8880 & Fev.1964 & 92,0 & 816 & 70.585 & 2.117 .756 & 6.905 & 11.508 & 11.508 & 18.414 & 817.102 & 6.905 & 55.241 & 25.319 & 1.054 .177 & $\begin{array}{r}11.082 \\
92.068\end{array}$ & 8.963 & & & & & & \\
\hline & 6100 & Mar.1964 & 71,1 & 440 & 38.025 & 1.140 .765 & 9.626 & 11.231 & 17.649 & 24.067 & 361.001 & 17.649 & 20.858 & 28.880 & 521.446 & 123.542 & & & & & & & \\
\hline & 4510 & Abr. 1964 & 67,6 & 304 & 26.341 & 790.248 & 7.014 & 9.352 & 12.859 & 16.366 & 198.729 & 9.352 & 64.295 & 21.042 & 351.867 & 94.688 & & & & & & & \\
\hline & 3500 & Maio-1964 & 37,7 & 131 & 11.400 & 342,014 & 8.165 & 3.629 & 9.072 & 17.237 & 54.432 & 4.536 & 22.680 & 18.144 & 153.317 & 44.453 & & & & & & & \\
\hline & 2689 & Jun.1964 & 30,5 & 81 & 7.062 & 211.871 & 9.031 & 6.252 & 20.840 & 11.809 & 17.366 & 1.389 & 2.084 & 11.115 & 89.610 & 38.206 & & & & & & & \\
\hline & 2490 & Ju1.1964 & 24,4 & 60 & 5.249 & 157.489 & 3.873 & 4.518 & 11.617 & 17.426 & 9.036 & 387 & 4.518 & 3.227 & 80.031 & 19.362 & & & & & & & \\
\hline & 2250 & Ag. 1964 & 30,2 & 67 & 5.870 & 176.126 & 4.082 & 4.082 & 6.719 & 12.247 & 10.498 & 583 & 2.916 & 11.664 & 61.236 & 60.070 & & & & & & & \\
\hline & 1990 & Out.1964 & 40,4 & 80 & 6.946 & 208.396 & 3.611 & 5.674 & 8.253 & 8.769 & 35.591 & 2.063 & 8.769 & 11.864 & 85.624 & 35.591 & & & & & & & \\
\hline & 3130 & Out.1970 & 39,0 & 122 & 10.546 & 405 & .094 & 1.094 & 9.207 & 13.792 & 52.734 & 3.245 & 487 & & .920 & .773 & & & & & & & \\
\hline
\end{tabular}

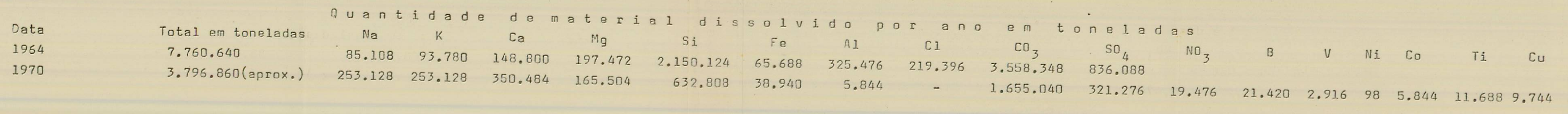


b - Quantidade de material dissolvido por $\mathrm{km}^{2}$ /ano.

Na Tabela 33 apresentamos a quantidade de todos os elementos dissolvidos por $\mathrm{km}^{2}$ /ano.

Os resultados do rio Paraná em Jupiá em 1964 são mais exatos onde tivemos dados de vazão durante todo o ano. Para os outros rios, os resultados por mês são exatos, mas por ano apenas aproximados, pois baseam-se nos cálculos de média a partir de um mês.

E necessário considerar que tanto o carbona to como o nitrato e parte do cloreto, são de origem atmosférica, parcialmente ou totalmente, portanto não podem ser considerados como derivados exclusivamente a partir das rochas e dos solos. $8 \%$ de carbonato e $0,9 \%$ de nitrato devem ser deduzidos do total do mate rial das águas dos rios (Clarke, 1924), os quais se riam de contribuição atmosférica.

Os dados apresentados nas tabelas são especí ficos para cada ano, uma vez que as concentrações dos elementos variam segundo o mês e ano. 
TABELA 33

Cálculo da quantidade dos elementos dissolvidos em $\mathrm{km}^{2} / a n$

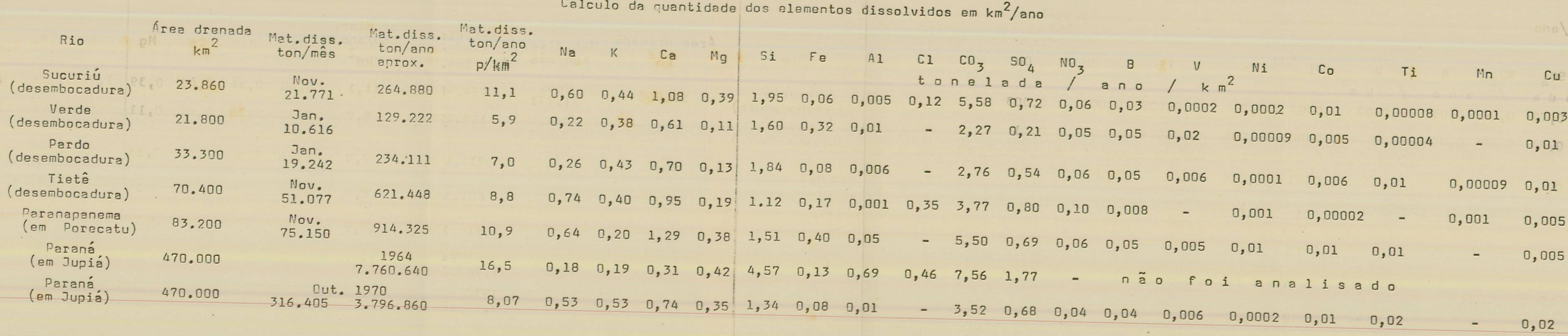


VI. COMPARAÇÕES ENTRE AS COMPOSIÇÕES QUIMICAS DOS RIOS BRASILEIROS ESTUDADOS COM OUTROS RIOS E OCEANOS.

a - Comparação de rios brasileiros com rios da Amé ria do Sul.

Na Figura 29 apresentamos as comparações entre os valôres médios dos elementos maiores obtidos em nosso estudo, com os valôres médios de rios da América do sul.

Observa-se na Figura 29, que as concentrações dos elementos dos rios estudados são mais baixas em sọ dio, potássio, cálcio, ferro e cloretos do que os de mais rios do continente sul-americano.

Concentrações mais altas do que a média dos valôres para o resto do continente sul-americano foram obtidos para o magnésio, silício, carbonato, sulfato e nitrato.

As concentrações médias dos constituintes las águas dos rios estudados e dos rios da América do Sul, estão apresentados na Tabela 34. 


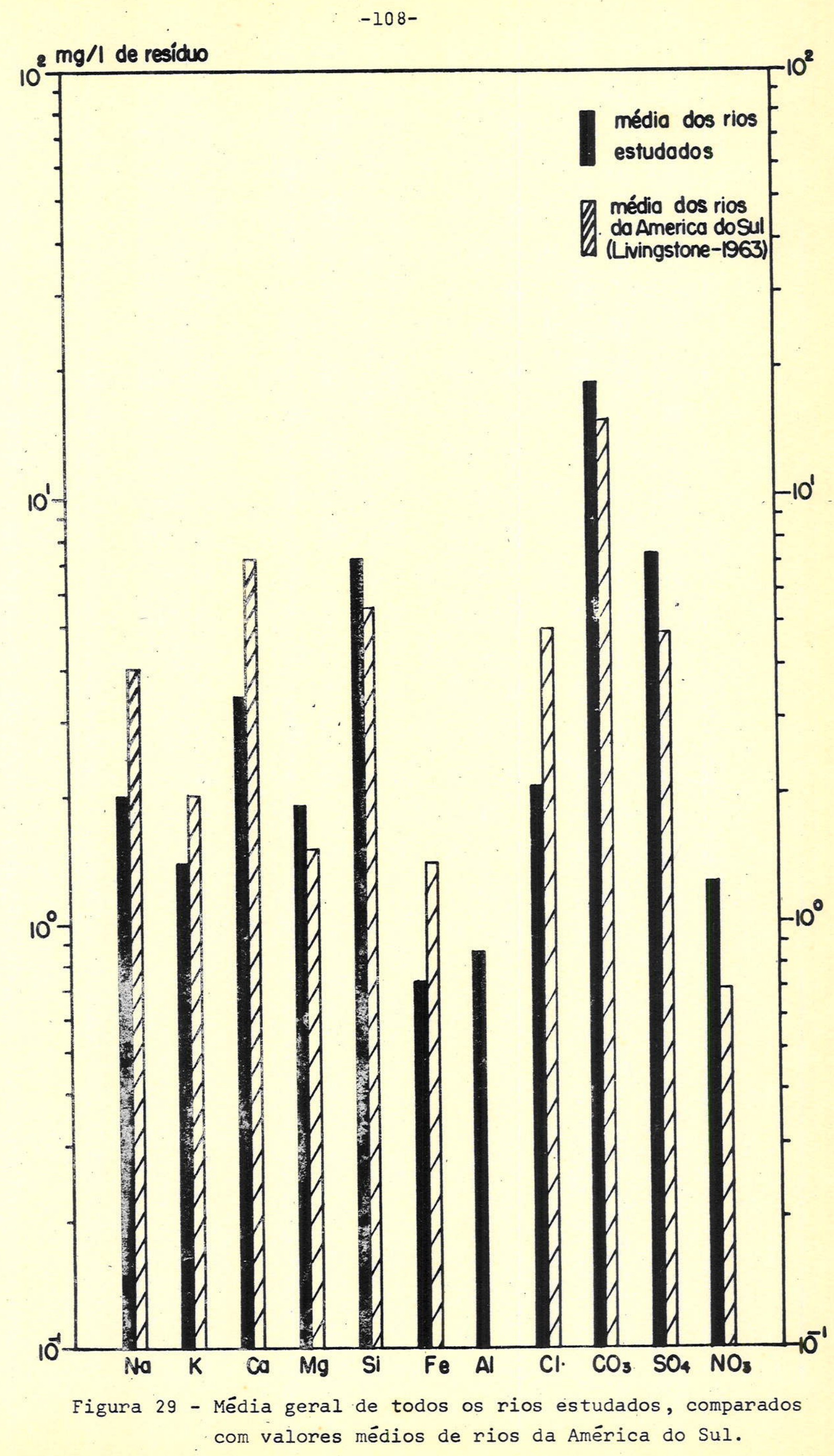


TABELA 34

Composição média dos rios estudados comparada com a média dos rios da América do Sul(mg/1)

\begin{tabular}{|c|c|c|c|c|c|c|c|c|c|c|c|c|}
\hline & $\mathrm{Na}$ & K & $\mathrm{Ca}$ & Mg & $5 i$ & $\mathrm{Fe}$ & Al & $\mathrm{Cl}$ & $\mathrm{CO}_{3}$ & $\mathrm{SO}_{4}$ & $\mathrm{NO}_{3}$ & Total \\
\hline Média dos rios & 2,0 & 1,4 & 3,4 & 1,9 & 7,2 & 0,72 & 0,86 & 2,1 & 18,4 & 7,4 & 1,25 & 46,63 \\
\hline
\end{tabular}

Média dos rios

da América do

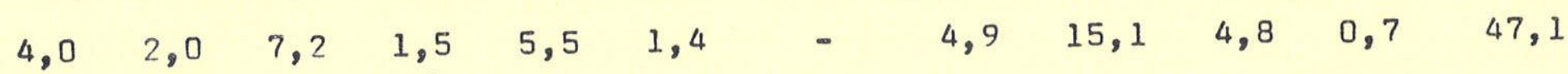

Sul 
A quantidade total de material dissolvido é bas tante semelhante, apesar de haver discrepância em dados isolados, o que em parte poderia ser explicado pela lito logia homogênea da área estudada. Os rios estudados pos suem altas concentrações em silício e valôres menores de cálcio em relação aos demais rios sul-americanos.

b - Comparação dos elementos traços dos rios estudados com os de outros países e Oceanos.

Na Tabela 35 comparamos a média das concentra ções dos elementos traços dos rios estudados, com a mé dia das concentrações de grandes rios dos Estados Unidos da América do Norte, da União Soviética, do Japão e dos Oceanos.

Os dados da Tabela 35 estão representados na Fí gura 30.

A Figura 30 mostra que os rios brasileiros es tudados possuem valôres médios maiores em alumínio, boro, vanádio, cobalto, titânio e cobre, sendo a média do ní quel maior nos rios da União Soviética e a do manganês nos rios dos Estados Unidos da América do Norte.

Como se observa na Figura 30 existe um teor al to em boro, vanádio, titânio e cobre nos rios estudados, em relação aos outros países. o boro foi detectado em concentrações elevadas nos folhelhos da Formação Irati, 
TABELA 35

Comparação dos elementos traços $(\mathrm{mg} / \mathrm{l})$

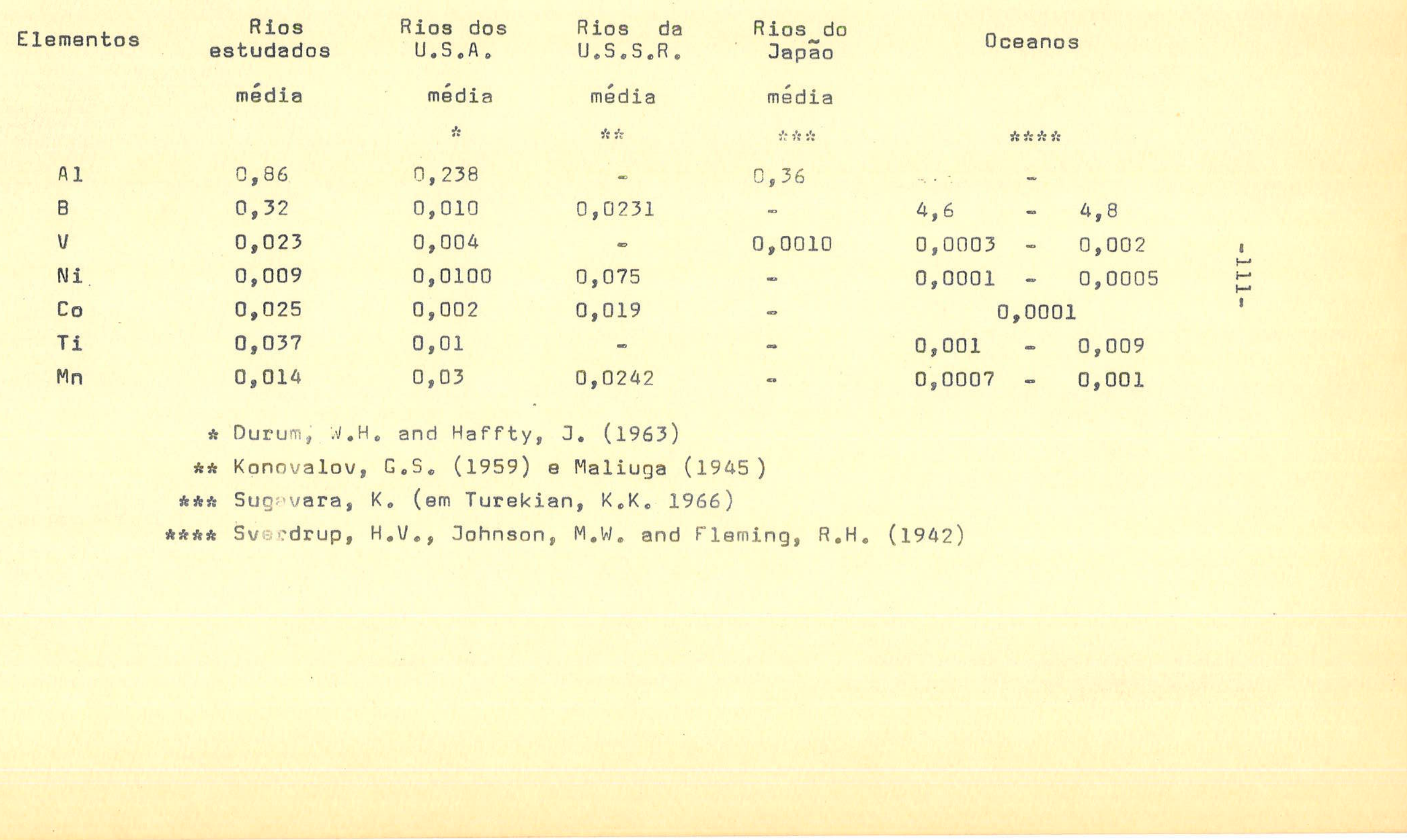




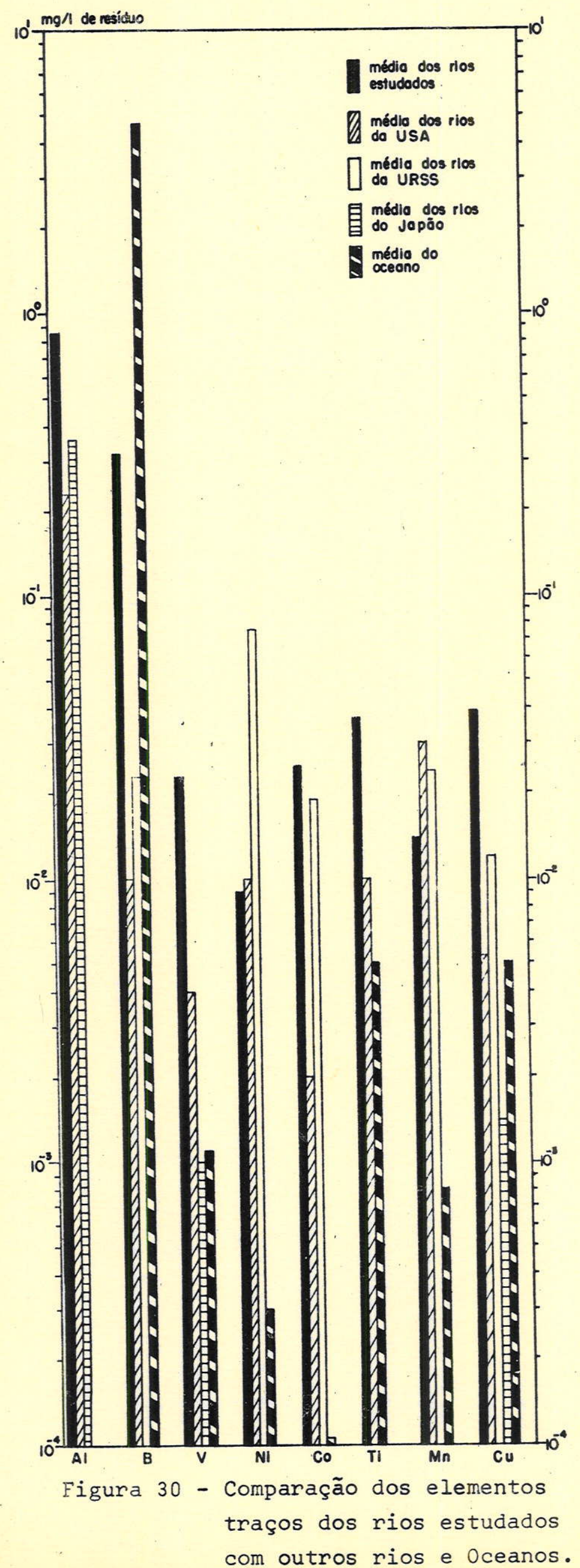


por Amaral (1967). Os basaltos estudados e analisados por Ruegg (1969) também mostraram concentrações altas para titânio, vanádio e cobre.

Uma característica dos rios dos Estados Uni dos da América do Norte é seu valor médio constante pa ra a razão Ni/Cu. Durum e Haffty (1963) estudaram essa relação, mostrando que a média para rios dos Estados Unidos da América do Norte varia de 1,3 a 2,6, aumentan do para as grandes latitudes do Norte (rios Yukon, Fra zer, Mackenzie e Nelson). Nas latitudes do Sul essa re lação tende a diminuir, sendo no rio Orange. (Sudoeste da Africa) ao redor de 0,07 .

A média da razão $\mathrm{Ni} / \mathrm{Cu}$ dos rios estudados é 0,50 .

Os autores acima citados explicam que o fato dêstes valôres diminuirem nas latitudes sul, é devido a vegetação e a atividade biológica nos climas quentes onde os organismos retiram das águas êstes elementos ne cessários ao seu crescimento.

Não se deve esquecer que os dados referentes aos rios estudados, tanto em elementos maiores e meno res como em elementos traços, são de uma ärea onde os rios drenam regiões de litologia com pouca variação, ou, que as rochas predominantes desta região são os basal tos, o que não é válido para as áreas drenadas pelos outros rios comparados. 


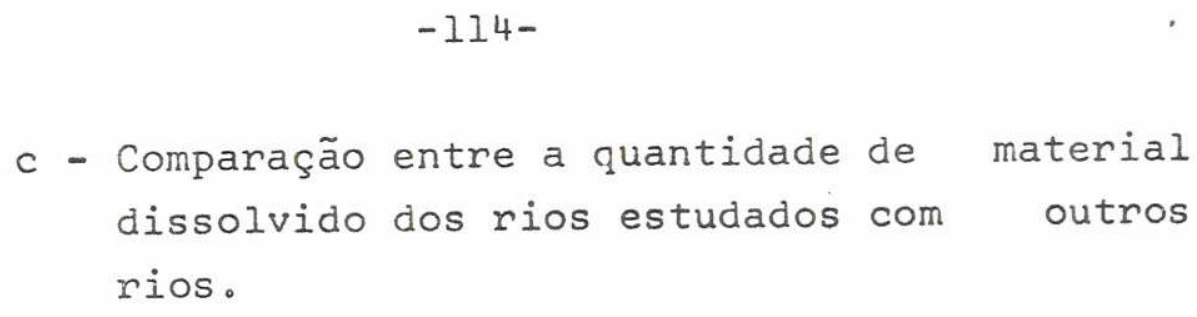

Finalmente comparamos o material dissolvido pelas águas dos rios analisados com os do rio Amazonas, Paraíba, Congo e Mississippi. Na Tabela 36 apresenta mos estas comparações.

\section{TABELA 36}

Comparação da quantidade de material dissolvido

\begin{tabular}{|c|c|c|c|c|}
\hline Rios & \multicolumn{2}{|c|}{$\begin{array}{l}\text { Material em } \\
\text { solução } \\
10^{6} \text { ton/ano }\end{array}$} & $\begin{array}{l}\mathrm{km}^{2} / \mathrm{ano} \\
\text { ton. }\end{array}$ & \multirow[t]{2}{*}{$\begin{array}{c}\text { Area drenada } \\
\mathrm{km}^{2}\end{array}$} \\
\hline Amazonas (Bacia) & 232 & $*$ & 116 & \\
\hline Paraíba & 3,0 & $* *$ & & \\
\hline Congo (Bacia) & 98,5 & $* * *$ & 37 & \\
\hline Mississippi(Bacia) & 118 & $* * * *$ & 100 & \\
\hline Paraná-Jupiä(1964) & 77,6 & & 16,5 & 470.000 \\
\hline Tietê (1970) & $6,2($ & aprox.) & 8,8 & 70.400 \\
\hline Sucuriú (1970) & 2,6 & $"$ & 11,1 & 23.850 \\
\hline Verde (1971) & 1,2 & $"$ & 5,9 & 21.800 \\
\hline Pardo (1971) & 2,3 & $"$ & 7,0 & 33.300 \\
\hline Paranapanema(1970) & 9,1 & $"$ & 10,9 & 83.200 \\
\hline * Gibbs, R.J. ( & $(1967)$ & & & \\
\hline$*$ Leinz, V. e A & Amaral, & .E. (I & $969)$ & \\
\hline$* * *$ Spronck, R. ( & (1941) & & & \\
\hline$* *$ Livingstone, & D.A. ( I & 3) & & \\
\hline
\end{tabular}


VII. CONCLUSÕES

Os resultados apresentados no presente tra balho, permitem-nos tirar as seguintes conclusões em re lação a concentração dos elementos em solução:

a. - Quanto a Iitologia:

Pode-se afirmar que a litologia e seu deri vado o solo, é o fator principal que controla a qualida de e em parte a quantidade do material em solução trans portado pelas águas dos rios.

Comparando-se a concentração dos elementos das águas coletadas nos rios situados nas margens direi ta e esquerda do rio Paraná, verificou-se que, com ex ceção do potássio, silício, cobalto e cobre, as maiores concentrações estão na margem esquerda.

b - Quanto a variação sazonal:

Existe variação da quantidade de material em solução e na concentração dos elementos com a mudan ça das estações.

No verão as äguas contêm mais material em solução do que no inverno, o que está em desacôrdo com resultados de outros rios de regiões de climas diferen ties do Brasil.

o responsável por esta concentração maior é o silício, que aliás, é o único elemento que mostrou grande variação com as estações. 

das apenas para regiões de basaltos, pois no rio Paraí ba, que drena área de rochas do embasamento cristalino, Szikszay (1967) verificou que a quantidade de material em solução é maior durante o inverno, corroborando re sultados de outros autores. Mesmo neste caso, o silí cio mostrou concentração maior durante o verão.

Comparando as médias $\mathrm{Na} / \mathrm{K}$ e $\mathrm{Ca} / \mathrm{Mg}$ com as de outros rios do Mundo, conclui-se que nas águas dos rios estudados (clima tropical e subtropical) deve existir mais potássio e magnésio em solução do que nas águas de rios de outros climas. Essas razões coincidem com aque las da Âricia, Ásia, Austrália e demais países da Améri ca do Sul, onde existem climas semelhantes aos do Bra sil.

Mesmo assim a litologia (rochas e solos) é - principal fator responsävel pelas concentrações dos elementos, cabendo ao clima uma influência secundária.

c - Quanto a vazão:

Os resultados mostram que a quantidade de material em solução é maior quando a vazão é máxima,con tràriamente aos resultados de outros autores. 0 respon sável por êsse fato é o silício, o qual se encontra dis solvido em grandes porcentagens nas épocas de maior va zão (verão).

0 aumento da vazão mostra um aumento nas concentrações do silício, alumínio, ferro e carbonatos 
e uma diminuição do sódio, cálcio e magnésio.

d - Quanto o $\mathrm{pH}$ :

Sendo o $\mathrm{pH}$ mais ou menos constante

nas águas dos rios, sua influência na concentração dos ele mentos é pequena. Aumentando $\circ \mathrm{pH}$, a concentração do alumínio e sulfato aumenta, enquanto o cálcio e ferro diminuem.

e - Os nitratos não variam com a variação sazo nal, vazão ou $\mathrm{pH}$.

f - As águas estudadas podem ser classificadas de carbonatadas, sendo êste um fato comum em rios de re giões de clima tropical e subtropical.

g - Os cloretos, em alguns casos, mostraram cer ta tendência de diminuição com $\circ$ afastamento dos pontos de coleta, do mar.

h - A quantidade de material em solução é supẹ rior ao material em suspensão ( $75 \%$ das análises), quando a coleta é feita na superfície da água do rio, valendo para coletas efetuadas no mesmo dia ou durante o ano.

i - A comparação da média das concentrações das águas dos rios estudados com a média de rios do contí nente sul-americano, mostrou concordância para a quanti dade total do material em solução, e discrepância na mé dia da concentração de vários elementos. 
VIII. BIBLIOGRAFIA

ALEKIN, O.A. and BRASHNIKOVA, L.V. - 1957 - New data on the average composition of river water for the territory of the USSR: Akad.Nauk SSSR Doklady, V. 114, 1062 - 1065 pp.

AMARAL, S.E. - 1967 - Contribuição ao conhecimento geológico, petrográfico e sedimentológico da Formação Irati no Estado de São Paulo. No prelo.

Bacia do Rio da Prata - 1969 - Secretaria Geral da Orga nização dos Estados Americanos, Washington, D.C.

BEURLEN, K. - 1970 - Geologie von Brasilien. Gebrueder Borntraeger, Berlin, Stuttgart, 293-324 pp.

BIgARELLA, J.J. e SALAMUNI, R. - 1967 - Some paleogra phic and paleotectonic features of the $\mathrm{Pa}-$ raná Basin. - Problems in Brazilian Gondwa na Geology: Curitiba, Brazil, 235 - 301 pp.

BORTOLUZZI, C.A. e BARBERENA, M.C. - i967 - The Santa Maria Beds in Rio Grande do Sul (Brazil) Problems in Brazilian Gondwana Geology: Cu ritiba, Brazil, 169 - 195 pp.

BRAIDECH, M.M. and EMERY, F.R. - 1935 - The spectrographic determination of minor chemical constituents in various water supplies in the United States: Am. Water Works Assoc.Journ., V. $27,557-580 \mathrm{pp}$.

CLARKE, F.W. - 1924 - The Data of Geochemistry. United States Geol. Survey Bull. 770 - Washington Govern. Printing Press, 63 - 121 pp.

CLARKE, F.W. - 1924a - The composition of the river and lake waters of the United States:U.S.Geol. Survey Prof. Paper 135, 1 - 199 pp. 
CLERFAYT, A. - 1956 - Composition des eaux de rivières au Congo. Influence des facteurs geologiques et climatiques: Centre Belge d'Etude et de Documentation des Eaux. V. 31, 26 $31 \mathrm{pp}$.

COLLINS, W.D. and WILLIAMS, K.T. - 1933 - Chloride and sulfate in rain water, Ind. Eng. Chem. 25, $944 \mathrm{pp}$.

Comissão de Solos - 1960 - Levantamento de Reconhecimen to dos Solos do Estado de São Paulo. Bol. No 12. Serviço Nacional de Pesquisas Agronomicas.

CONWAY, E.J. - 1942 - Mean geochemical data in relation to oceanic evolution. - Proc.Roy. Irish Acad. B. 48, $119-159$ pp.

CORDANI, U.G. e VANDOROS, P. - 1967 - Basaltic Rocks of the Parana Basin. - Problems in Brazilian Gondwana Geology: Curitiba, Brazil, 207 $231 \mathrm{pp}$.

CORRENS, C.W. - 1941 - The geochemistry of halogens. Phy sics and chemistry of the earth; London, Pergamon Press, V。 1. 181' - 233 pp.

DAVIS, S.N. - 1964 - Silica in streams and ground water: Am. Jour. Sci. V. 262,870-891 pp.

DURUM, W.H. and HAFFTY, J. - 1960 - Occurrence of minor elements in water. U.S. Geol. Survey Circ. $445,11 \mathrm{pp}$.

DURUM, W.H. and HAFFTY, J. - 1963 - Implication of the minor element content of some major streams of the world. Geochimica et Cosmochimica Acta, V. $27, \mathrm{n}: 1,1$ - 11 pp.

ENERGLYN, The Lord and BREALEY, L. - 1971 - Analytical Geochemistry and Geophysics. 5. - Elsevier Publishing Company, Amsterdam, London, New York, $213-243 \mathrm{pp}$. 
FREITAS, R.O. - 1955 - Sedimentação, Estratigrafia e Tectônica da Série Bauru (Estado de São Paulo).Bol. No 194. Geologia n: 14 da USP, FFCL. 75 - 80 pp.

GIBBS, R.J. - 1967 - The Geochemistry of the Amazon River System: Part I. The Factors that control the salinity and the composition and concentration of the suspended solids.-Geol. Soc. of America Bull. V. 78, no 10. 1023$1232 \mathrm{pp}$.

GOLDSCHMIDT, V.M. and PETERS, C. - 1932d (Ibid. 528) Nachr. Ges. Wiss. Goettingen, math-phys.KI. $65,281 \mathrm{pp}$.

GOLDSCHMIDT, V.M. - 1958 - Geochemistry. Oxford, At the Clarendon Press, 730 pp.

GORHAM, E. - 1958 - The influence and importance of dai ly weather conditions on the supply of chloride, sulphate and other ions to fresh waters from the atmospheric precipitation: Royal Soc. (London) Philos. Trans., B. V. 241,147 - $178 \mathrm{pp}$.

GUTMANS, M. - 1949 - Tectônica da Bacia do Paraná. Eng. Min. Metal. 1480 Rio de Janeiro, 47 - 49 pp. HANYA, T., and SUGAVARA, K. - 1950 - Geochemical studies on Suyashima Island IV. Origin of the chemical constituents in the fluvial waters and correlation between them: Chem. Soc. Ja pan Journ. Pure Chem. Sec., V. 71, 389 $392 \mathrm{pp}$.

HARDER, H. - 1965 - Experimente zur "Ausfaellung" der Kieselsaure. Geochimica et Cosmochimica Acta, V. $29,429-442$ pp.

HARRISON, J.B. and REID, K.D. - 1913 - Official Gazette, Georgetown, Demerara.

HAWKES, J.E. and WEBB, J.S. - 1962 - Geochemistry in Mineral Exploration - Harper \& Row,Publishers, New York and Evanston, 415 pp. 
HEIDE, F. - 1952 - Die Geochemie der Suesswaesser: Chemie Erde, V。 16, I - 21 pp。

HUTTON, J.T. and LESLIE, T.I. - 1958 - Accession of non nitrogenous ions dissolved in rainwater to soils in Victoria: Australian Jour.Agr. Research, V。9, 492- 507 pp.

IWASAKI, I. and NITTA, T. - $1954 \mathrm{a}$ - Geochemical investi gations of rivers. III: Chem. Soc. Japan Jour. Pure Chem. Sec., V. 75, 548 - 552 pp.

IWASAKI, I. and NITTA, T. - 1954b - Geochemical investi gations of rivers. IV: Chem.Soc. Japan Jour. Pure Chem. Sec., V. 75, 1123 - 1126 $\mathrm{PP}$.

JUNGE, C.E. and WERBY, R.T. - 1958 - The concentration of chloride, sodium, potassium, calcium and sulfate in rain water over the United States: J. Meteorology 15, $417-425$ pp.

KATZER, F. - 1903 - Grundzuege der Geologie des unteren Amazongebietes, Leipzig.

KHARKAR, D.P., TUREKIAN, K.K。 and BERTINE, K.K。 - 1968 Stream supply of dissolved silver, molybde num, antimony, selenium, 'chromium, cobalt, rubidium and cesium to the oceans. Geochimica et Cosmochimica Acta, 1968, V。32, 285 - 298 pp.

KIMURA, K., NOGUCHI, K。, HANYA, T., TORII, T. and URAHAWA, N. - 1950 - Chemical constituents of well waters and river waters in Manchuria: Chem. Soc. Japan Jour. Pure Chem. Sec., V. $71,263-266,448-451$ pp.

KLEINKOPF, M.D. - 1955 - Trace element exploration of Mai ne Lake water. $\mathrm{Ph}$. D. dissertation, Columbia University, University Microfilm Pub. 12, v. 447, $157 \mathrm{pp}$.

KLEINKOPF, M.D. - 1960 - Spectrographic Determination of trace elements in lake waters of Northern Maine. Bull.Geol.Soc.America 71,(7 - 9), 1231 - 1241 pp。 
KOBAYASHI, J. - 1960 - A chemical study of the average quality and characteristics of river waters of Japan: Ber. Ohara Inst. Landwirtschaft. Biol., V. 11. $313-358$ pp.

KONOVALOV, G.S. - 1941 - Hydrochemical method of prospec ting for gold: Problemy, Soviet Geol. 1941, v. 2. $114-117 \mathrm{pp}$.

KONOVALOV, G.S. - 1959 - The transport of microelements by the most important rivers of the USSR: Akad. Nauk SSSR Doklady, V. 129, N? 4. 912 - 915 pp.

KRAUSKOPF, K.B. - 1967 - Introduction to Geochemistry. McGraw Hill Book Comp. 721 pp.

KYLE, J.J. - 1897 - La composicion quimica de las aguas de la republica Argentina. I. Rios y Arroyos: An. Soc. Cient. Argentina, V. 43, $19-25$ pp.

LEINZ, V. - 1937 - Estudos sôbre a glaciação permocarbo nifera do sul do Brasil. Serv.Fom.da Prod. Min. D.N.P.M. Min.Agric. Bol.21, 47 pp.

LEINZ, V. - 1949 - Contribuição à geologia dos derrames basálticos do Sul do Brasil. Fac. Fil. Cí ên. Letr. USP, Bol.103, Geologia, n: 5, São Paulo.

LEINZ, V. e AMARAL, S.E. - 1969 - Geologia Geral. Comp. Editora Nacional. 119 - 131 pp.

LEVERIN, H.A. - 1947 - Industrial Waters of Canada. Report on investigation, 1934 - 1943: Rept. Canada Dept. of Mines and Resources Bur. of Mines, n० 819, 109 pp.

LIVINGSTONE, D.A. - 1963 - Data of Geochemistry, Chapter G. Chemical composition of rivers and lakes. Geol. Survey Professional Paper 440 G, G1 - $652 \mathrm{pp}$.

LUCAS, A. - 1908 - The chemistry of the River Nile:Egypt, Survey Dept., Cairo, Paper n: 7, 78 pp. 
MAACK, R. - 1955 - Comentärios sôbre o mapa geológico da América do Sul. Com. Interest.da Bac. Paraná-Uruguai. Secr. Geral da Org. dos Está dos Americanos, Washington, D.C. 1969. Bacia do rio da Prata. V. 1. $69-75$ pp.

MAGNANINI, R.L. da C. - 1955 - Observações sôbre o clima da Bacia Paraná-Uruguai. Com. Interest. da Bacia Paraná-Uruguai. Condições geográficas e aspectos geoeconomicos da Bacia Para ná-Uruguai. Secr. Ger. da Org. dos Est. Amer., Washington, D.C. 1969, Bacia do rio da Prata, V。1. 103 - 110 pp.

MALDONADO, A. and GUEVARA, J. de D. - 1950 - Boron in the waters and soils of Peru: Agronomia (Peru), V. $16,51-67$ pp.

MALIUGA, D.P. - 1945 - Content of copper, nickel, cobalt and other elements of the iron family in na tive waters: Akad. Sci. URSS, Comptes Rendus, 113 - $116 \mathrm{pp}$.

MASON, B. - 1952 - Principles of Geochemistry: John Wiley and Sons Inc., New York. 184 - 198 pp.

MENDES, J.C. - 1967 - The Passa Dois Group. (The Brazilian portion of the Paraná Basin). - Problems in Brazilian Gondwana Geology, Curitiba, Brazil, 120 - 166 pp.

MENDES, J.C. e PETRI, S. - 1971 - Geologia do Brasil. Inst. Nacional do Livro. Minist. da Educação e Cultura. 61 - $110 \mathrm{pp}$.

MORAES REGO, L.F. - 1935 - Camadas Cretáceas do Sul do Brä sil. Anna. Esc. Pol. S.Paulo, IV. ano $2 \underline{\text { a }}$ ser. 231 - 166 pp.

OKAMOTO, G., OKURA, T. and'GOTO, K. - 1957 - Properties of silica in water. Geochimica et Cosmochimica Acta, V. 12, $123-132 \mathrm{pp}$.

PARAGUASSU, A.B. - 1968 - Contribuição ao estudo da Formą ção Botucatú: sedimentitos aquosos, estrutú ras sedimentares e silicificação. Tese de doutoramento. 
PASTORE, F. and HUIDOBORO, O.J.R. - 1952 - Geology of she et $24 \mathrm{~g}$, Saladillo, San Luiz: Argentina Rept. Minst.Ind. y Com. Div.Nac.Mineria, Bol. V. $78,53 \mathrm{pp}$.

PEDRO, G. - 1970 - L'evolution des sols et la carcterisation des phenomenes d'alteration superficiel le dans la zone basaltique du Parana. (Bresil) - I.N.R.A. Departement d'Agronomie - La boratoire des Sols.

POVINELLI, J. e PARAGUASSU, A.B. - 1966 - Geoquímica das àguas dos rios: Quilombo, Chibarro, Araras e Negro, S.P.: trab. apres. na XVIII Reunião Anual da SBPC, Blumenau, S.C. res.publ. em Ciência e Cultura, V. 18, no 2, São Pau$10,210 \mathrm{pp}$.

RANKAMA, K. and SAHAMA, TH. G. - 1949 - Geochemistry - The University of Chicago Press. 909 pp.

ROCHA CAMPOS, A.C. - 1967 - The Tubarão Group on the Brazilian Portion of the Parana Basin. Problems in Brazilian Gondwana Geology: Curitiba,Bra zil, 27 - 102 pp.

ROMARIZ, D. de A. - 1955 - A vegetação original da Bacia Paraná-Uruguai. Com. Interest. da Bacia Paranä-Uruguai. Secr. Ger. da Org. dos Est. Americanos, Washington, D.C. 1969, Bacia do Rio da Prata. V. 1, 111 - 131 pp.

RUEGG, N.R. - 1969 - Aspectos geoquímicos, mineralógicos e petrográficos de rochas basālticas da Bacia do Paraná. Tese de Doutoramento.

RUEGG, N.R. e DUTRA, C.V. - 1970 - Novas anälises de alguns elementos traços em rochas basálticas da Bacia do Paraná, Ciência e Cultura, V.22, $\mathrm{n}$ : $1,15-20 \mathrm{pp}$.

SALAMUNI, R。 e BIGARELLA, J.J. - 1967 - The pre-Gondwana Geology. Problems in Brazilian Gondwana Geo logy: Curitiba, Brazil, 3 - 24 pp. 
SALAMUNI, R. e BIGARELLA, J.J. - 1967 - The Botucatu For mation. Problems in Brazilian Gondwana Geo logy: Curitiba, Brazil, 197 - 206 pp.

SCHNEIDER, A.W. - 1964 - Contribuição à petrologia dos derrames basálticos da bacia do Paraná.Univ. do Rio Grande do Sul. Esc.de Eng.Publ.Avul sa n̊ 1, Pôrto Alegre, 5 - 76 pp.

SCHUETLE, K.H. and ELSWORTH, J.F。 - 1954 - The significan ce of large $\mathrm{pH}$ fluctuations observed in some South African veis: Journ. Ecology, V. 42,148 - $150 \mathrm{pp}$.

SIEVER, R. - 1962 - Silica solubility, $0^{\circ}-200^{\circ} \mathrm{C}$, and the diagenesis of siliceous sediments:Journ. Geol. V. 70, 127 - 150 pp.

SINELLI, 0. - 1970 - Geologia e ăgua subterrânea no Município de Ribeirão Prêto e Adjacências, Tese de Doutoramento.

SPRONCK, R。 - 1941 - Mesures hydrographiques effectuées dans la region divagante du Bief Maritime du Fleuve Congo: Brussels, Inst. Royale Colonial Belge Memoire, 156 pp.

STUEBER, A.M。, HUANG, W.H. and JOHNS, W.D. - 1968 Chlorine and fluorine abundance in ultramafic rocks. Geochimica et Cosmochimica Acta. V. $32.353-358 \mathrm{pp}$.

SVERDRUP, H.V., JOHNSON, M.W. and FLEMING, R.H. - 1942 The Oceans, Prentice Hall, New York.

SZIKSZAY, M。 - 1967 - Exame espectrogräfico semi-quantitativo de elementos traços na água do rio Paraíba. Bol.da Soc.Bras.de Geol. V. 16, n? $2,61-77$ pp.

SZIKSZAY, M. - 1969 - Exame espectrogrä́fico dos elementos maiores, menores e elementos traços nas águas do rio Tietê. Mineração e Metalurgia, V. L., n: $297, \cdots 133-137$ pp. 
SZIKSZAY, M. - 1969 - Adaptação de Padrões espectrográficos para análise de minerais e rochas. Tese de mestrado.

TARDY, Y. - 1971 - Characterization of the principal weathering types by the geochemistry of waters from some European and African crystalline massifs. Chemical Geology. V. $7, \mathrm{n}: 4,253-271 \mathrm{pp}$.

TUREKIAN, K.K. - 1966 - Trace elements in sea water and other natural waters: Annual Report AEC Contract AT(30-1) - 2912, Publ. Yale 2912 - 12. 59 pp.

TUREKIAN, K.K. - 1969 - The Oceans, Streams and Atmosphere, in Handbook of Geochemistry, Sprin ger Verlag, Berlin, Heidelberg, New York, 296 - 323 pp.

de VILLIERS, P.R. - 1962 - The Chemical Composition of the Water of the Orange River at Vioolsdrif, Cape Province. Annals of the Geological Survey, V. 1. $198-206$ pp.

WEDEPOHL, K.H. - 1969 - Handbook of Geochemistry, Springer Verlag, Berlin, Heidelberg, New York, II. V. $442 \mathrm{pp}$.

YAMAMOTO, S. - 1952 - Chemical composition of river water in Manchuria: Jap. Journ. Geology and Geography, V. 22, 97 - 109 pp. 